KARINA PANIZZI GIMENES

\title{
EFEITO DO EGF NA REGULAÇÃO DOS TRANSCRITOS DE GENES IDENTIFICADOS COMO DIFERENCIALMENTE EXPRESSOS EM CÉLULAS DE MAMA EM CULTURA APRESENTANDO DIFERENTES NÍVEIS DE EXPRESSÃO DE
} ERBB2

\author{
Dissertação apresentada ao Programa \\ de Pós-graduação Interunidades em \\ Biotecnologia USP/Instituto Butantan/ \\ IPT, para obtenção do Título de Mestre. \\ Área de Concentração: Biotecnologia \\ Orientadora: \\ Prof $^{\mathrm{a}}$. Dr ${ }^{\mathrm{a}}$. Maria Aparecida Nagai \\ SÃO PAULO \\ 2008
}


DADOS DE CATALOGAÇÃO NA PUBLICAÇÃO (CIP)

Serviço de Biblioteca e Informação Biomédica do

Instituto de Ciências Biomédicas da Universidade de São Paulo

(c) reprodução total

Gimenes, Karina Panizzi.

Efeito do EGF na regulação dos transcritos de genes identificados como diferencialmente expressos em células de mama em cultura apresentando diferentes níveis de expressão de erbb2 / Karina Panizzi Gimenes. -- São Paulo, 2008.

Orientador: Maria Aparecida Nagai.

Dissertação (Mestrado) - Universidade de São Paulo. Instituto de Ciências Biomédicas. Programa de Pós-Graduação Interunidades em Biotecnologia USP/IPT/Instituto Butantan. Área de concentração: Biotecnologia. Linha de pesquisa: Genética molecular do câncer.

Versão do título para o inglês: EGF effects in the regulation of gene transcripts identified as differentially expressed in human mammary cell lines expressing different levels of erbb2.

Descritores: 1. Neoplasia mamária 2. Gene - ERBB2 3. Expressão gênica 4. Fator de crescimento epitelial 5 . Cultura de células I. Nagai, Maria Aparecida II. Universidade de São Paulo. Instituto de Ciências Biomédicas. Programa de Pós-Graduação em Biotecnologia III. Título. 
Candidato(a):

Título da Dissertação:

Orientador(a):
Karina Panizzi Gimenes.

Efeito do EGF na regulação dos transcritos de genes identificados como diferencialmente expressos em células de mama em cultura apresentando diferentes níveis de expressão de erbb2.

Maria Aparecida Nagai.

A Comissão Julgadora dos trabalhos de Defesa da Dissertação de Mestrado, em sessão pública realizada a ... ..

\section{( ) Aprovado(a) \\ ( ) Reprovado(a)}

Examinador(a): Assinatura:

Nome:

Instituição:

Examinador(a): Assinatura:

Nome:

Instituição:

Presidente: Assinatura:

Nome:

Instituição: 
Aos meus pais e heróis

Nelson e Eliana

Que sempre estiveram ao meu lado e que sem o apoio, amor e força eu nunca teria realizado nada. Obrigada por me darem confiança, na certeza de estar indo por caminhos corretos e por estarem sempre dispostos a me amparar quando tropeço. A vocês, que são as pessoas mais perfeitas do mundo, muito obrigada. 
A minha maravilhosa irmã Patrícia

e ao meu cunhado Alexandre

Pelo carinho, paciência e por sempre estarem ao meu lado. Por dizerem o que eu queria ouvir quando meus pais falavam o que eu não esperava.

A querida Giovana por ser uma grande alegria em minha vida.

\section{Ao meu namorado Vinicius}

Pelo carinho, incentivo e apoio. Por sempre estar disposto a me ajudar e por me alegrar com tanta facilidade.

"Quero a vida sempre assim, Com você perto de mim..."

Tom Jobim 


\section{AGRADECIMENTOS}

A Dra. Maria Aparecida Nagai pela orientação desse projeto e por todos os ensinamentos; também por todos os puxões de orelha, que foram válidos e merecidos.

Às queridas amigas do laboratório:

Débora, por ser essa pessoa tão especial, carinhosa e paciente, que sempre me ajudou em tudo que fiz, além de ser uma amiga maravilhosa.

Diana, por me ensinar a reação de real time, além de se tornar uma grande amiga.

Mariana, por me ensinar a cultura de células e muitas outras coisas; por ser minha companheira de samba e uma grande amiga que posso ligar sempre que precisar.

Lucimari e Yuri pelos momentos de descontração.

Simone, pelo exemplo de dedicação e força e pela risada contagiante.

Ana Carolina, pela animação na organização das festinhas do laboratório.

Michelle, pela companhia tranqüila que acompanhou o início deste trabalho.

Michelly, Cláudia e Thaís pelo apoio no dia a dia.

Emerson, por sempre me fazer rir com seus sonhos mirabolantes.

Dona Antonia, pela companhia animada e pelo bom humor.

Sibeli, pela dedicação no preparo das soluções do laboratório. 
A Kátia, por sempre estar disposta a me ouvir e me aconselhar.

Ao Tarsício e a Mara pelas várias ajudas no western blot e apoio sempre que precisei.

A minha querida prima Fernanda pela amizade, apoio e pelas gargalhadas.

Á Teresa por ser minha amiga mais antiga e mais perfeita que sempre acreditou em mim, muitas vezes mais que eu mesma; ao Léo que por tabela se tornou um grande amigo (não que ele não tivesse méritos para isso).

À Aline por ser obrigada a me agüentar nessa essa etapa final sem nunca reclamar.

Ao Nicholas por ser um amigo tão querido que sempre esteve presente na minha vida me apoiando, é as vezes não muito. 
Onde você vê a morte, Alguém vê o fim E o outro vê o começo de uma nova etapa... Onde você vê a teimosia, Alguém vê a ignorância, Um outro compreende as limitações do companheiro, percebendo que cada qual caminha em seu próprio passo.

E que é inútil querer apressar o passo do outro, a não ser que ele deseje isso. Cada qual vê o que quer, pode ou consegue enxergar "Porque eu sou do tamanho do que vejo E não do tamanho da minha altura." 


\section{LISTA DE ABREVIATURAS}

AKT oncogene homólogo ao thimona viral v-akt murino

AP-1 proteína de ativação 1

ATPase constitui uma família de enzimas que catalisam a hidrólise do ATP

ATRX Alpha thalassemia/mental retardation syndrome X-linked

BRCA 1 Câncer de mama 1

BRCA 2 Câncer de mama 2

cAMP 3', 5' monofosfato cíclico de adenosina

CCND1 ciclina D1

cDNA ácido desoxiribonucléico complementar

c-myc oncogene homólogo a mielocitomatose viral v-myc

coX-2 ciclo oxigenase 2

CT Threshold Cycle

dNTPs 2' desoxirribonucleotídeos 5' trifosfato

DNA ácido desoxirribonucléico

E2 17ß-estradiol

EDTA Ácido etileno diamino tetracético

EGF Fator de crescimento epitelial

EGFR receptor do fator de crescimento epidermal

ER $\alpha \quad$ receptor de estrógeno alfa

ERBB2 oncogene homólogo a leucemia eritroblástica viral v-erb-b2 2, oncogene homólogo ao neuro / glioblastoma

fos oncogene homólogo ao ostiosarcoma viral murino v-fos FBJ

HRG heregulina $\beta 1$

INCA Instituto Nacional do Câncer

jun oncogene homólogo ao v-jun sarcoma vírus 17

kDa quilo Dalton

MAPs proteínas associadas a microtúbulos

MAPK proteína quinase ativada pelo mitógeno

mRNA RNA mensageiro

MOPS ácido propanesulfônico 3-[N-morfolino]

$\mathrm{Na}_{3} \mathrm{VO}_{4}$ Ortovanadato de sódio 
NF-kB fator nuclear do gene "enhancer" do polipeptídeo leve Kappa nas células-B1

p21 inibidor $1 \mathrm{~A}$ da quinase dependente de ciclina

pb pares de base

PCR reação em cadeia da polimerase (Polimerase Chain Reaction)

qPCR reação em cadeia da polimerase quantintativa

PI3K fosfatidil inositol 3 quinase

PMSF fenilmetilsulfonilflorideo

RNA ácido ribonucléico

SAGE análise seriada da expressão gênica (Serial Analysis of Gene Expression)

SAPK proteína quinase ativada por stress

VEGF fator de crescimento endovascular 


\section{LISTA DE FIGURAS}

Figura 01 Estrutura dos receptores ERBB2 e ERBB3 21

Figura 02 Vias de sinalização dos receptores de fatores de 24 crescimento epitelial

Figura 03 Gel representativo da qualidade e integridade de amostras 53 de RNA

Figura 04 Amplificação dos transcritos GAPDH e $\beta$-micro em amostras das células C5.2 para verificação da qualidade e integridade do cDNA sintetizado.

Figura 05 Curva de amplificação e gráfico de dissociação da reação 54 de PCR em tempo real

Figura 06 Análise da expressão do oncogene ERBB2 nas células 55 HB4a, C5.2 e SKBr3

Figura 07 Expressão relativa do mRNA dos genes ATAD4, MATR3, 56 NDRG1, ANP32B, ACTN1, CENPH, TPM1 e SPARC nas células HB4a, C5.2 e SKBr3.

Figura 08 Expressão relativa dos transcritos ATAD4 nas células $\mathrm{HB} 4 \mathrm{a}, \quad 57$ C5.2 e SKBr3 tratadas com EGF

Figura 09 Expressão relativa dos transcritos ATAD4 nas células $\mathrm{HB} 4 \mathrm{a} \quad 58$ e SKBr3 tratadas com HRG

Figura 10 Expressão relativa dos transcritos NDRG1 nas células 59 HB4a, C5.2 e SKBr3 tratadas com EGF

Figura 11 Expressão relativa dos transcritos NDRG1 nas células HB4a 60 e SKBr3 tratadas com HRG

Figura 12 Expressão relativa dos transcritos $A N P 32 B$ nas células 61 HB4a, C5.2 e SKBr3 tratadas com EGF

Figura 13 Expressão relativa dos transcritos $A N P 32 B$ nas células 61 HB4a e SKBr3 tratadas com HRG

Figura 14 Expressão relativa dos transcritos MATR3 nas células 62 HB4a, C5.2 e SKBr3 tratadas com EGF

Figura 15 Expressão relativa dos transcritos MATR3 nas células HB4a 62 e SKBr3 tratadas com HRG 
Figura 16 Expressão relativa dos transcritos ACTN1 nas células 63 HB4a, C5.2 e SKBr3 tratadas com EGF

Figura 17 Expressão relativa dos transcritos $A C T N 1$ nas células HB4a 63 e SKBr3 tratadas com HRG

Figura 18 Expressão relativa dos transcritos TPM1 nas células HB4a, 64 C5.2 e SKBr3 tratadas com EGF

Figura 19 Expressão relativa dos transcritos TPM1 nas células HB4a e 64 SKBr3 tratadas com HRG

Figura 20 Expressão relativa dos transcritos CENPH nas células 65 HB4a, C5.2 e SKBr3 tratadas com EGF

Figura 21 Expressão relativa dos transcritos $C E N P H$ nas células HB4a 65 e SKBr3 tratadas com HRG

Figura 22 Expressão relativa dos transcritos SPARC nas células HB4a 66 e C5.2 tratadas com EGF

Figura 23 Expressão relativa dos transcritos SPARC nas células HB4a 66 tratadas com HRG

Figura 24 Expressão relativa dos transcritos EGFR nas células $\mathrm{Hb} 4 \mathrm{a}, \quad 67$ $\mathrm{C} 5.2$ e SKBr3

Figura 25 Expressão relativa do RNAm do gene ERBB2 e Western 68 Blot nas células C5.2 transfectadas com siERBB2.

Figura 26 Expressão relativa dos transcritos ATAD4 e ACTN1 nas 69 células C5.2 transfectadas com si controle negativo e siERBB2.

Figura 27 Expressão relativa dos transcritos NDRG1, SPARC e 70 MATR3 nas células C5.2 transfectadas com si controle negativo e siERBB2..

Figura 28 Expressão relativa dos transcritos TPM1 e CENPH nas 71 células C5.2 transfectadas com si controle negativo e SiERBB2.

Figura 29 Expressão relativa dos transcritos $A N P 32 B$ nas células C5.2 71 transfectadas com si controle negativo e siERBB2. 


\section{SUMÁRIO}

1 INTRODUÇÃO 18

2 OBJETIVOS 34

3 MATERIAIS E MÉTODOS 36

$\begin{array}{ll}3.1 \text { Cultura celular } & 37\end{array}$

3.2 Extração de RNA 38

3.3 Tratamento com DNase 39

3.4 Síntese de cDNA 39

$\begin{array}{lll}3.5 \text { RT-PRC } & 40\end{array}$

3.6 PCR em Tempo Real 40

$\begin{array}{ll}3.7 \text { Ensaio de siRNA } & 41\end{array}$

3.8 Extração de proteínas 42

3.9 Western Blot 43

3.10 Análise Estatística 43

4 RESULTADOS 44

4.1 Análise da expressão dos transcritos ERBB2, MGC11242, MATR3, 45 NDRG1, ANP32B, ACTN1, CENPH, TPM1 e SPARC nas linhagens HB4a, C5.2 e SKBr3

4.2 Curva de concentração versus tempo de exposição ao EGF 46

4.3 Tratamento das células HB4a e SKBr3 com Heregulina $\beta 1$

4.4 Ensaios de siRNA 52

5 DISCUSSÃO 73

$\begin{array}{lll}5.1 S P A R C & 74\end{array}$

$5.2 N D R G 1 \quad 76$

$\begin{array}{lll}5.3 \text { ACTN1 } & 76\end{array}$

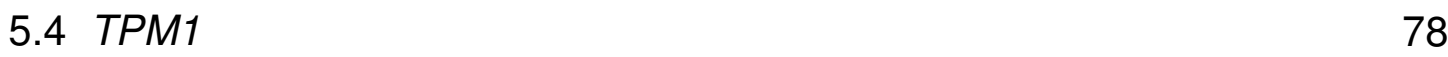

$\begin{array}{ll}5.5 \mathrm{CENPH} & 79\end{array}$

5.6 ATAD4 80

6 CONCLUSÃO 81

REFERÊNCIAS BIBLIOGRÁFICAS 83 


\section{RESUMO}

GIMENES, K.P. Efeito do EGF na regulação dos transcritos de genes identificados como diferencialmente expressos em células de mama em cultura apresentando diferentes níveis de expressão de ERBB2. 2008. 108 f. Dissertação (Mestrado) - Instituto de Ciências Biomédicas, Universidade de São Paulo, São Paulo, 2008.

O câncer de mama é a neoplasia de maior ocorrência na população feminina. A etiologia dos tumores de mama é complexa e está relacionada a um conjunto de fatores endógenos e exógenos. A amplificação gênica mais freqüente em câncer de mama é a do oncogene ERBB-2, observada em aproximadamente $30 \%$ dos tumores de mama. A expressão aumentada de ERBB-2 está relacionada com ausência de receptor de estrógeno e menor intervalo livre de doença e sobrevida total das pacientes com câncer de mama. O ERBB-2 ativa importantes vias de sinalização celular, incluindo as vias MAPK e PI3K que regulam processos biológicos como proliferação celular, angiogênese e inibição da apoptose. Não é conhecido um fator de crescimento que se ligue ao homodímero ERBB2, entretanto este é o parceiro preferido na formação de heterodímeros com os outros membros da família. Neste estudo, utilizando PCR em tempo real, foi analisado o efeito do EGF na regulação da expressão dos genes ANP32B, MATR3, ATAD4, NDRG1, ACTN1, SPARC, TPM1 e CENPH, nas células HB4a, C5.2 e SKBr3, que expressam diferentes níveis de ERBB2. Avaliou-se também o perfil de expressão destes transcritos na linhagem C5.2 após a supressão da expressão do ERBB2 pela técnica de siRNA. Nas células HB4a os tratamentos com EGF reduziram a expressão dos transcritos ATAD4, NDRG1, CENPH e SPARC e aumentaram a expressão dos transcritos ACTN1 e TPM1. Houve diminuição na expressão dos transcritos dos genes ATAD4, ANP32B, MATR3, CENPH e SPARC e aumento dos transcritos NDRG1 e ACTN1 nas células C5.2 tratadas com EGF. Os tratamentos com EGF reduziram a expressão dos transcritos do ATAD4, NDRG1, ANP32B, MATR3 e CENPH nas células SKBr3. Os resultados do ensaio de RNAi mostraram que após a transfecção das células C5.2 com siRNA para o gene ERBB2 houve redução dos transcritos ATAD4 e NDRG1 e uma tendência de redução dos transcritos, ACTN1, SPARC e MATR3.. As células C5.2 
transfectadas com siERBB2 mostraram aumento na expressão dos transcritos do CENPH e TPM1. Observou-se que os tratamentos com EGF modulam de forma diferente a expressão dos transcritos analisados nas células HB4a, C5.2 e SKBr3. Além disso, a expressão dos transcritos estudados também foi alterada após o silenciamento do ERBB2 nas células C5.2.

Palavras-chaves: Neoplasia mamária; Gene ERR2; Expressão gênica; Fator de crescimento epitelial; Cultura de célula. 


\section{ABSTRACT}

GIMENES, K.P. EGF effects in the regulation of gene transcripts identified as differentially expressed in human mammary cell lines expressing different levels of ERBB2. 2008. 108 f. Master thesis - Instituto de Ciências Biomédicas, Universidade de São Paulo, São Paulo, 2008.

Breast cancer is the more frequent neoplasia in women. Breast cancer etiology is complex and is related to several exogenous and endogenous factors. The more frequent genic amplification observed in breast cancer is that of the ERBB2 oncogene, which occurs in approximately $30 \%$ of the breast cancers. Overexpression of this gene is associated with lack of estrogen receptor, and lower disease-free interval and survival of all patients with breast cancer. The ERBB-2 protein activates important cell signaling pathways such as MAPK and PI3K, regulating biological processes such as cell proliferation, angiogenesis and inhibition of apoptosis. It is not known any growth factor which binds ERBB2; however ERBB2 is the preferred partner for heterodimerisation with all the other family members. In the present study, using real time PCR, it was investigated the effect of EGF on $A N P 32 B, M A T R 3$, ATAD4, NDRG1, ACTN1, SPARC, TPM1 and CENPH transcripts regulation in the HB4a, C5.2 and SKBr3 cell lines, that express different levels of ERBB-2. It was also evaluated the expression profile of these transcripts in the C5.2 cell line after the suppression of ERBB2 expression by the siRNA technique. In HB4a cells, EGF treatment reduced the expression of ATAD4, NDRG1, CENPH and SPARC transcripts and increased the expression of ACTN1 and TPM1 transcripts. There was a decrease in the expression of the transcripts of the genes ATAD4, ANP32B, MATR3, CENPH and SPARC and an increase in NDRG1 and ACTN1 in C5.2 cells treated with EGF. The treatments with EGF reduced the expression of ATAD4, NDRG1, ANP32B, MATR3 and CENPH transcripts in SKBr3 cells. The RNAi results showed that after transfection of C5.2 cells with siRNA for the gene ERBB2 there was a reduction on ATAD4 and NDRG1 transcripts expression, and a tendency to reduce the transcripts ACTN1, SPARC and MATR3. The C5.2 cells transfected with siERBB2 showed an increase in the expression of CENPH and TPM1 transcripts. It was observed that the treatments with EGF modulate differently the expression of the 
analysed transcripts in HB4a, C5.2 and SKBr3 cells. Moreover, the expression of the studied transcripts was also modulated by the silencing of ERBB2 in cells C5.2.

Keywords: Mammary neoplasia; ERBB2 gene; Gene expression; Epidermal growth factor; Cell culture. 
INTRODUÇÃO 


\section{INTRODUÇÃO}

A carcinogenese é um processo com múltiplas etapas iniciando-se a partir de uma alteração genética em uma única célula a qual se torna geneticamente instável e outras alterações genéticas e epigenéticas são sucessivamente acumuladas (PONDER, 2001). Ativação de oncogenes, inativação de genes supressores de tumores, mutações pontuais, deleções, rearranjo, amplificação e expressão aumentada de genes são alguns tipos de alterações genéticas associadas ao desenvolvimento de uma neoplasia (BARCUS et al., 2000). Hanahan e Weinberg (2000) classificaram 6 características adquiridas pelas células durante o desenvolvimento maligno: auto suficiência em sinais de crescimento, indiferença a sinais antiproliferativos, inibição da apoptose, potencial replicativo ilimitado, angiogênese, invasão de tecidos e metástase.

Embora a maioria dos tumores seja originada por mutações somáticas, 5 a $10 \%$ dos casos de câncer de mama são devido a mutações germinativas (CLAMP et al., 2002). Uma grande proporção dos cânceres de mama hereditários é devidos a mutações nos genes BRCA1 e BRCA2 (DE JONG et al., 2002). Estes genes, localizados nos cromossomos 17q21 e 13q12, respectivamente, são considerados genes "de guarda", agindo como sensores de danos no DNA e participando do processo de reparo (OLDENBURG et al., 2007). Além dos genes BRCA1 e BRCA2 outros genes como PTEN, TP53, ATM, CDH1 estão associados ao câncer de mama da forma familial. (OLDENBURG et al., 2007).

A história familiar é o principal fator de risco para o câncer de mama, o risco de uma mulher desenvolver câncer de mama aumenta no mínimo duas vezes se algum parente de primeiro grau tiver a doença antes dos 50 anos (MCPHERSON et al., 2000).

A etiologia dos tumores de mama é complexa e está relacionada a um conjunto de fatores endógenos e exógenos. Alguns dos fatores exógenos estão relacionados com o estilo de vida como dieta rica em gordura e obesidade que aumenta 2 vezes o risco do desenvolvimento de câncer de mama após a menopausa (CLAMP et al., 2002; MCPHERSON et al., 2000). O consumo de álcool está associado com o risco de desenvolvimento de câncer de mama em 
mulheres na pré e pós menopausa (TRICHOPOULOS et al., 2008; MCPHERSON et al., 2000).

Outros fatores de risco estão relacionados à exposição da mama a hormônios esteroídicos, como gravidez depois dos 30 anos de idade, nuliparidade, menarca precoce ou menopausa tardia, uso de contraceptivos orais e reposição hormonal (MCPHERSON et al., 2000).

O desenvolvimento da glândula mamária é influenciado por diversos fatores de crescimento, entre eles o fator de crescimento epitelial (EGF) e seus receptores, que são diferencialmente expressos nas células estromais e/ou epiteliais mamárias durante os estágios do desenvolvimento (CASALINI et al., 2004).

A família do receptor de fator de crescimento epitelial (EGFR), também conhecida como ERBB e HER, é constituída pelo ErbB1 (também chamado de HER-1 ou EGFR), ErbB2 (Neu ou HER-2), HER-3 ou ErbB3 e HER-4 ou ErbB4. Esta família de receptores tirosina quinase (RTK) possui um domínio transmembrânico que separa a região tirosina quinase intracelular da porção extracelular de ligação ao ligante (ULLRICH e SCHLESSINGER, 1990). A região extracelular é composta por quatro domínios (I-IV) com alta homologia estrutural (WARREN e LANDGRAF, 2006). Os domínios I e III são ricos em leucina e importantes para a ligação dos ligantes, enquanto os domínios II e IV são domínios ricos em cisteínas, sendo o domínio II responsável pela dimerização (CITRI e YARDEN, 2006).

Nos receptores EGFR, ERBB3 e ERBB4 inativos o domínio II está ligado ao domínio IV, assumindo uma conformação que impede a exposição do braço de dimerização no domínio II. A ligação dos ligantes aos domínios I e III provoca uma mudança conformacional no receptor e a quebra das ligações intramoleculares dos domínios II e IV, expondo, assim, o braço da dimerização para interações intermoleculares (ROSKOSKI, 2004). A estrutura da região extracelular do receptor ERBB2 difere dos outros membros desta família. $O$ ERBB2 tem uma conformação fixa que se assemelha ao estado ativado pelo ligante, a interação entre os domínios II e IV está ausente e o braço de dimerização do domínio II está exposto (Figura 1) (GARRETT, et al., 2003; $\mathrm{CHO}$, et al., 2003). 


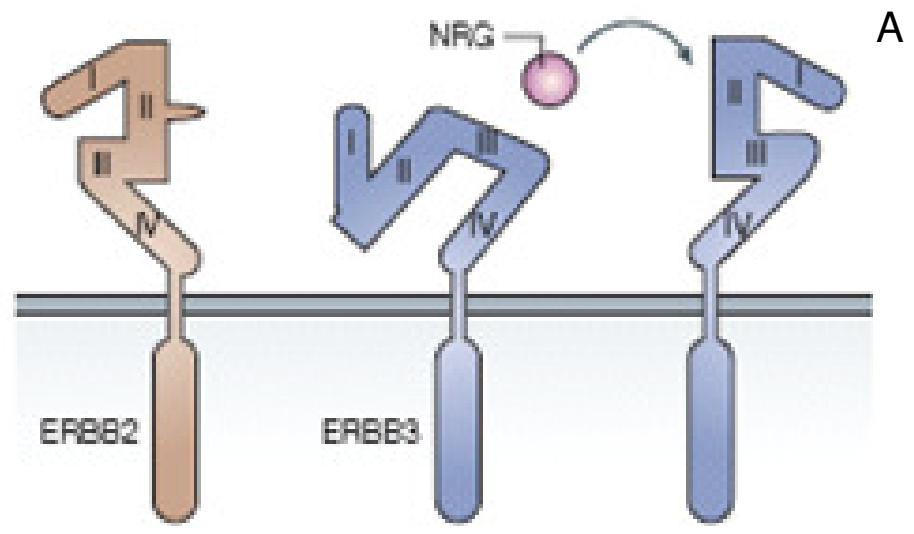

B
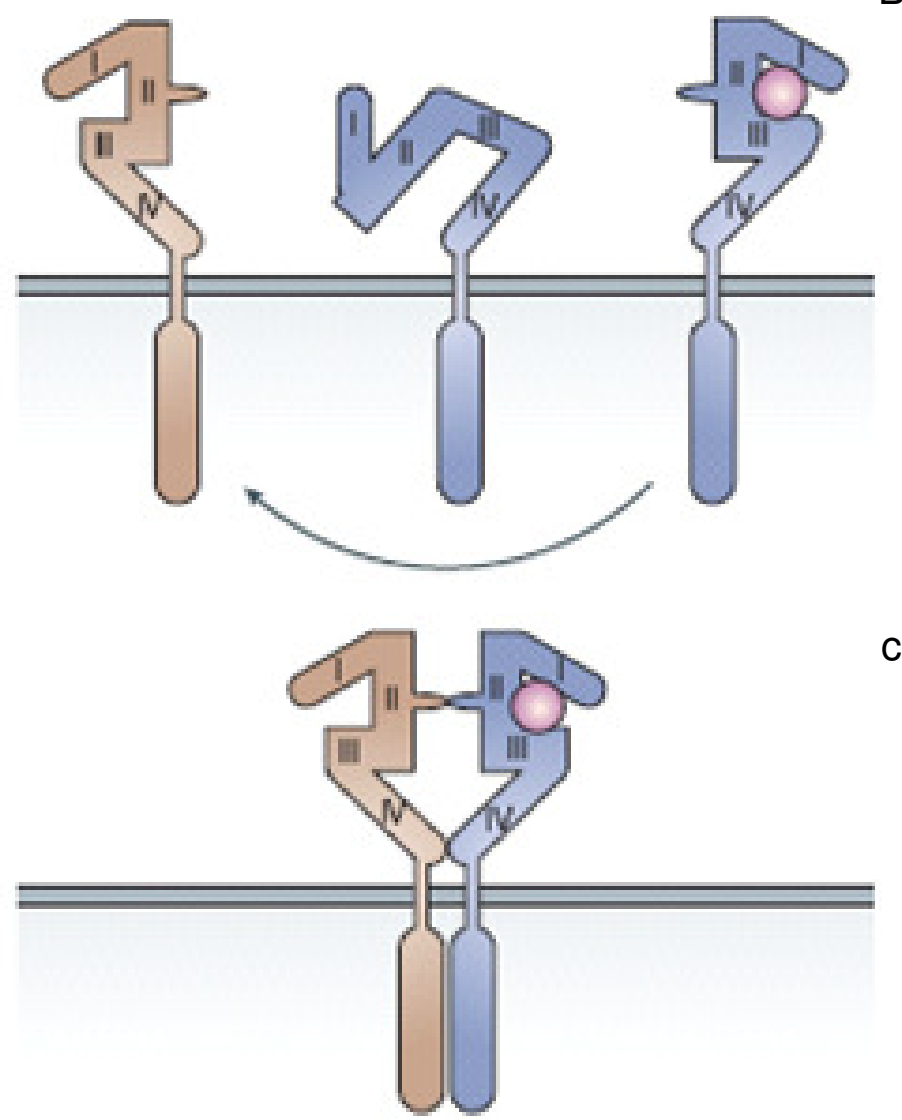

Figura 1: Estrutura dos receptores ERBB A- Região extracelular dos receptores ERBB2 e ERBB3 na ausência de ligantes; B- Domínios I e III envolvidos na ligação à neregulina e exposição do braço de dimerização no domínio II; C- dimerização dos receptores (HYNES e LANE, 2005) 
Os ligantes da família de receptores ERBB podem ser divididos em 3 grupos: o primeiro grupo é formado pelos ligantes que se ligam especificamente ao EGFR (EGF, amfiregulina, fator de crescimento e transformação $\alpha$ ), o segundo grupo inclui betacelulina, HB-EGF e epiregulina que se ligam ao EGFR e ao ERBB4. O terceiro grupo é composto pelas neregulinas capazes de se ligarem aos receptores ERBB3 e ERBB4 (HYNES e LANE, 2007). Esses diferentes ligantes possuem em comum um domínio de 45-55 aminoácidos incluindo seis resíduos de cisteína que interagem covalentemente formando três alças, responsáveis pela especificidade de ligação aos receptores ERBB (CASALINI et al., 2004). Não é conhecido um fator de crescimento que se ligue ao homodímero ERBB2 (ROSKOSKI, 2004), no entanto a importância do ERBB2 na resposta celular aos ligantes dos receptores ERBB é devido a sua habilidade de formar heterodímeros com outros membros da família (GRAUS-PORTA et al., 1997; HARRIS et al., 1999).

Em níveis normais de expressão do receptor, a ligação do ligante ao domínio extracelular provoca uma mudança conformacional que induz a dimerização do receptor, levando ao aumento da atividade quinase e autofosforilação dos resíduos de tirosina (GREENFIELD et al., 1989; ULLRICH e SCHLESSINGER, 1990). Os resíduos de tirosina fosforilados servem como sítios para moléculas sinalizadoras que possuem domínio PTB e SH2 como as moléculas adaptadoras Shc, Grb2, p85 e Crk, enzimas, fosfolipase $\mathrm{CY}$ e potenciais repressores de sinalização $\mathrm{CHK}$ e Dok-2 (BADACHE e GONÇALVES, 2006; HYNES e LANE, 2007). O recrutamento dessas moléculas adaptadoras é o primeiro evento da cascata de sinalização.

Dependendo do ligante, a família de receptores ERBB pode formar 4 homodímeros e 6 heterodímeros. O ERBB2 é o parceiro preferido na formação de heterodímeros, sendo os mais comumente encontrados ERBB2-ERBB3, ERBB2-ERBB4 e ERBB1-ERBB4 (GRAUS-PORTA et al., 1997; ZACZEK et al., 2007), esta característica pode ser explicada pela estrutura de sua região extracelular (HYNES e LANE, 2007). A heterodimerização aumenta a diversidade de ligantes reconhecidos pelos receptores individuais, além de permitir o recrutamento de diferentes moléculas sinalizadoras e adaptadoras, que ativam diferentes vias de sinalização (MUTHUSWAMY et al. 1999; YARDEN, 2001; ROSKOSKI, 2004). 
As principais vias de sinalização ativadas pelos receptores ERBB são as da proteína quinase ativada por mitógeno (MAPK), da proteína quinase ativada por stress (SAPK), da fosfatidilinositol 3` quinase (PI3K) e da proteína quinase C (PKC) (LIU et al., 1999; YARDEN e SLIWKOWSKI, 2001; NIU e CARTER, 2007) (Figura 2). A PI3K ativa AKT, uma proteína serina/treonina quinase que fosfosrila porteínas pró-apoptóticas como BAD, caspase-9, fatores de transcrição da família forkhead e NF-kB (SONG et al., 2005). Assim, as principais funções da via de sinalização PI3K/AKT são promover o crescimento celular mediado por fatores de crescimento, proliferação, migração e sobrevivência (NICHOLSON e ANDERSON, 2002). As SAPKs estão envolvidas na indução a apoptose em resposta a estímulos como radiação ionizante, choque térmico e estresse osmótico (NICHOLSON e ANDERSON, 2002), além de serem alvos da regulação de Akt/PKB na promoção da sobrevida celular (SONG et al., 2005). A via Ras/Raf/MEK/ERK através da regulação da expressão de vários genes e de muitas proteínas envolvidas na apoptose como BAD, Bim, Mcl-1 e caspase-9, controla a progressão do ciclo celular, apoptose e diferenciação (MCCUBREY et al., 2007). 


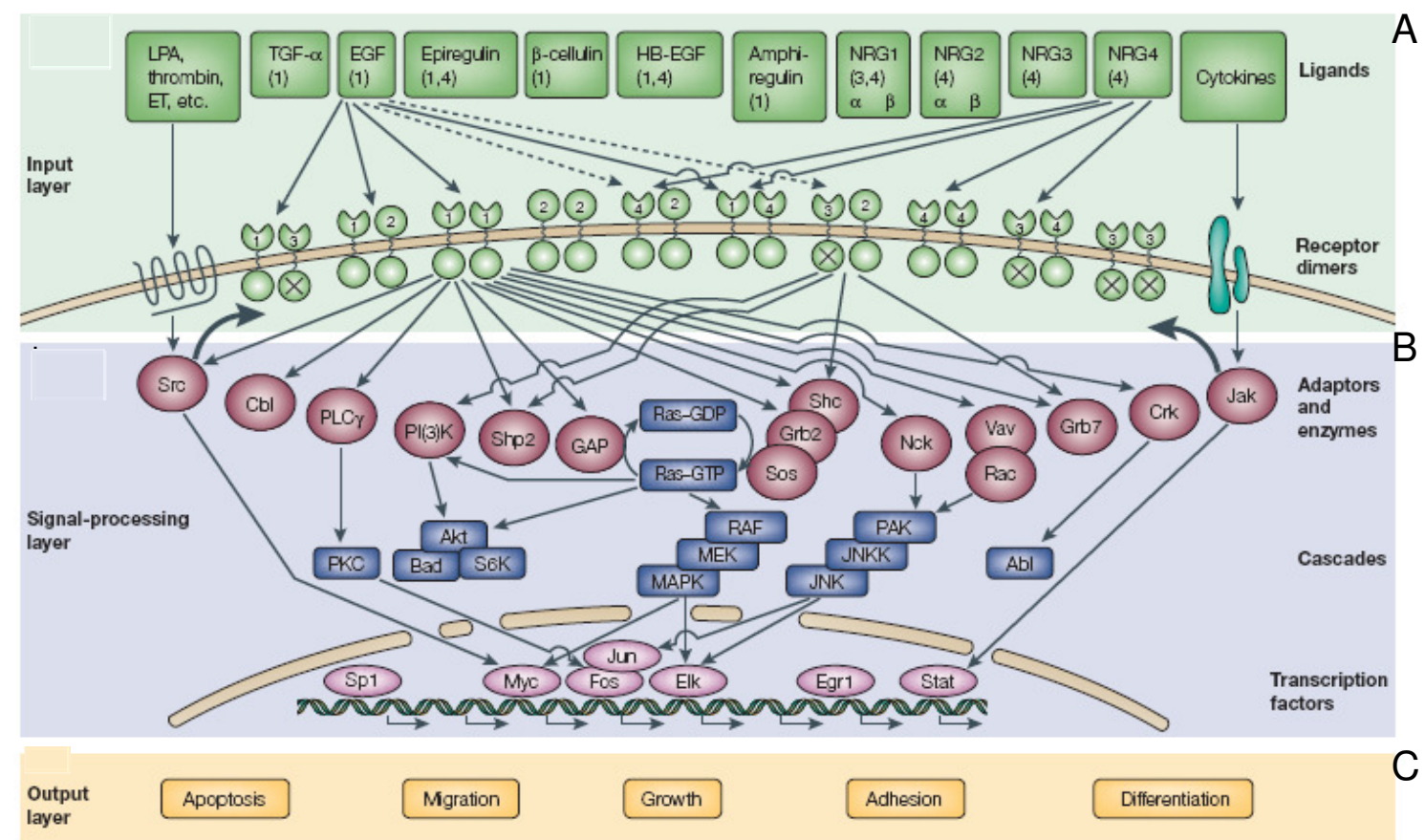

Figura 2: Vias de sinalização celular das proteínas ERBB. A - Ligantes e as 10 possíveis combinações de dímeros que a família de receptores de fator de crescimento epitelial podem formar. O número embaixo de cada ligante indica por qual receptor este apresenta maior afinidade. Para simplificar, a figura indica apenas as ligações do EGF e da NGR4 a seus receptores e não é conhecido ligante para o ERBB2. Homodímeros ERBB3 são cataliticamente inativos, pois esse membro não possui o domínio tirosina quinase. B - Vias de sinalização ativadas pelos receptores ERBB. C - Processos biológicos influenciados pela via da família ERBB (YARDEN e SLIWKOWSKI, 2001). 
A expressão aumentada dos membros da família de receptores ERBB, principalmente EGFR e ERBB2, e seus ligantes cognatos, têm sido relacionados à progressão de diferentes tipos de cânceres humanos (YARDEN e SLIWKOWSKI, 2001). A expressão aumentada do oncogene ERBB2, o qual se localiza no cromossomo 17q21 e codifica para uma glicoproteína transmembrânica de $185 \mathrm{kDa}$, é observada em câncer de ovário, pulmão, estômago, boca (HUNG e LAU, 1999) e em aproximadamente $30 \%$ dos tumores de mama (SLAMON et al., 1987; NAGAl et al., 1993). A amplificação gênica e o aumento da expressão desse gene estão relacionados com a ausência de receptor de estrógeno e com menor intervalo livre de doença e sobrevida total das pacientes com câncer de mama (NAGAl et al., 1993; DOWSETT et al., 2001; LEE et al., 2007). A expressão aumentada do gene ERBB2 também está associada ao envolvimento de linfonodos e ao alto grau histológico dos tumores de mama (HUSSEIN et al., 2008; LEE et al., 2007).

Células com expressão aumentada de ERBB2 mostram elevada proliferação dependente de mitógeno resultante da redução da fase $G_{1}$ do ciclo celular e consequentemente da entrada precoce na fase S (TIMMS et al., 2002). Outros estudos mostram que células e tumores com expressão aumentada de ERBB2 também apresentam elevada taxa de proliferação na ausência de mitógeno indicando a ativação constitutiva desse receptor (HARRIS et al, 1999; TIMMS et al., 2002; ROSKOSKI, 2004). O aumento da proliferação, segundo estudos realizados em células de mama que expressam diferentes níveis de ERBB2, ocorre principalmente pelas vias de sinalização MAPK e do fator de transcrição c-myc (TIMMS et al., 2002; HARRIS et al., 1999).

Tokunaga et al. (2006) verificaram que a ativação da via Akt/PKB foi significativamente maior em carcinomas primários de mama com expressão aumentada de ERBB2 e que a ativação desta via em pacientes com carcinoma primário de mama está relacionada à pior resposta a terapia hormonal (TOKUNAGA et al., 2006).

Considerado um importante alvo terapêutico, o oncogene ERBB2 tem sido muito estudado para o desenvolvimento de novas drogas, um exemplo disso foi o desenvolvimento da Herceptina ${ }^{\circledR}$ (trastuzumab). Aprovada em 1998 para tratamento de câncer de mama metastático, a Herceptina® é um anticorpo 
monoclonal que se liga ao domínio extracelular IV do receptor ERBB2 ( $\mathrm{CHO}$ et al., 2003). Muitos estudos indicam que a Herceptina® é ativa como agente único em pacientes com câncer de mama com expressão aumentada de ERBB2 (VOGE et al., 2002; COBLEIGH et al., 1999) e também pode ser administrada em combinação com drogas quimioterápicas como docetaxel, vinorelbina e paclitaxel, aumentando o índice de resposta ao tratamento (ADAMO et al., 2007). Após estudo realizado em 1694 mulheres com câncer de mama com expressão aumentada de ERBB2, Piccart-Gebhart et al. (2005) observaram que a Herceptina ${ }^{\circledR}$ quando administrada após a terapia primária reduz o índice de recorrência em aproximadamente 50\%. Comparada à quimioterapia isoladamente, esse fármaco aumenta o índice de resposta de 32 para 50\% e o tempo de progressão da doença de 4,6 para 7,4 meses (BALSEGA, 2001; MOSESSON e YARDEN, 2004).

Embora o mecanismo de ação da Herceptina ${ }^{\circledR}$ não esteja totalmente elucidado três modelos principais têm sido propostos: o primeiro modelo envolve a proteína $\mathrm{C}$-Cbl, uma ligase ubiquitina que se associa ao receptor erbB2 no endosomo resultando na monoubiquitinação, a qual leva ao lisossomo para subseqüente degradação. $O$ anticorpo por sua vez favoreceria o recrutamento da C-Cbl pelo ERBB2, acelerando a remoção do receptor da superfície das células e promovendo sua degradação intracelular. O segundo modelo de ação da Herceptina ${ }^{\circledR}$ é através da supressão da angiogenese via indução de fatores antiangiogênicos e repressão de fatores proangiogenicos como o fator de crescimento vascular endotelial (VEGF). Por fim, a terceira hipótese envolve a citotoxicidade celular dependente de anticorpo (ADCC) resultante da ativação de receptores $F c$ nas células imunes (YEON e PEGRAM, 2005; BADACHE e GONÇALVES, 2006).

Apesar de a Herceptina ${ }^{\circledR}$ ser um avanço no tratamento de pacientes com câncer de mama com expressão aumentada de ERBB2 esta não é eficaz em todos os casos. Apenas $15-26 \%$ das pacientes com câncer de mama com expressão aumentada de ERBB2 respondem a monoterapia (VOGEL, et al, 2002; RABINDRAN, 2005). A baixa resposta ao anticorpo pode ser devido ao domínio do ERBB2 onde a Herceptina $\AA^{\circledR}$ se liga, que não impede a heterodimerização do receptor (HYNES e LANE, 2005). 
Um segundo anticorpo desenvolvido para o tratamento de câncer de mama com expressão aumentada de ERBB2 é o pertuzumab. Este difere da Herceptina® por se ligar próximo ao braço de dimerização no domínio II do receptor ERBB2, inibindo a dimerização por impedimento estérico (PAL e PREGAM, 2007). In vitro, o pertuzumab inibe a proliferação dependente de heregulina de células de câncer de mama que expressam baixos e altos níveis de ERBB2 (RABINDRAN, 2005).

A expressão aumentada de ERBB2 é freqüentemente associada à resistência aos quimioterápicos e às terapias hormonais, sendo esse o principal problema clínico do tratamento e responsável pelo seu fracasso (DOWSETT et al., 2001). Entre os pacientes com tumores de mama primários com baixa expressão de ERBB2, 93\% respondem à quimioterapia e à hormônio terapia adjuvantes, enquanto nos pacientes com tumores expressando níveis elevados do receptor a resposta é observada em apenas $57 \%$ dos casos (MAKRIS et al, 1997). Células de câncer de mama com expressão aumentada de ERBB2 são mais resistentes aos quimioterápicos docetacel e paclitaxel quando comparadas a células que não apresentam alteração na expressão desse gene (UENO et al., 1997). Além disso, foi observado que tumores com altos níveis de HER2 são menos responsivos a terapia com tamoxifeno (SCHIFF et al., 2005). Porém, Pegran et al. (1997) após estudos in vivo e in vitro em células de câncer de mama sugeriram que apenas a expressão aumentada de ERBB2 não é suficiente para induzir resistência a drogas o que indica que outras alterações presentes nas células tumorais estejam associadas a quimioresistência.

Apesar do intenso estudo, genes regulados pela via do ERBB2 que podem contribuir para progressão e comportamento do tumor e influenciar na resposta ao tratamento com Herceptina ${ }^{\circledR}$ e na quimioresistência não são totalmente conhecidos. Estudo prévio do nosso grupo identificou os genes, SPARC, ATAD4 (MCG11242), ACTN1, TPM1, MATR3, ANP32B e CENPH como potencialmente regulados por ERBB2 em células de câncer de mama com diferentes níveis desse receptor (Tabela 1) (DOS SANTOS et al., 2006). A análise desses genes pode contribuir para melhorar a compreensão dos processos de tumorigênese e quimioresistência mediada pelo oncogene ERBB2 em tumores de mama. 
Tabela 1: Número de tags dos genes SPARC, ATAD4, ACTN1, TPM1, MATR3, $A N P 32 B$ e $C E N P H$ encontradas nas células HB4a e C5.2 pela análise de SAGE. *O gene NDRG1 apesar de não pertencer ao grupo de genes diferencialmente expressos por uma razão de no mínimo 4 vezes foi escolhido por ser um gene de interesse do nosso grupo.

\begin{tabular}{|c|c|c|}
\hline Genes & $\begin{array}{c}\text { N. de tags } \\
\text { HB4a }\end{array}$ & $\begin{array}{c}\text { N. de tags } \\
\text { C5.2 }\end{array}$ \\
\hline ATAD4 & 0,00 & 16,32 \\
\hline MATR3 & 0,00 & 230,52 \\
\hline$A N P 32 B$ & 2,00 & 18,36 \\
\hline ACTN1 & 23,0 & 1,02 \\
\hline TPM1 & 8,00 & 0,00 \\
\hline CENPH & 2,0 & 25,00 \\
\hline$S P A R C$ & 141,00 & 17,34 \\
\hline$N D R G 1^{*}$ & 2,0 & 4,08 \\
\hline
\end{tabular}

Fonte: DO SANTOS et al., 2006. 


\section{Secreted Protein Acidic and Rich in Cystein (SPARC)}

O gene SPARC, localizado no cromossomo 5q31.3-q32, codifica para uma glicoproteína secretada de $32 \mathrm{kDa}$ que interage com proteínas da matriz extracelular para promover adesão das células à matriz. A proteína SPARC tem papel importante na regulação da adesão celular, proliferação, migração remodelamento de tecidos e na progressão tumoral (FRAMSON e SAGE, 2004). O mecanismo pelo qual o SPARC modula a progressão do câncer é complexo e depende do tipo celular e do microambiente.

Análise pelas técnicas de microarray e por RT-PCR demonstrou uma redução na expressão do gene SPARC nas células com expressão aumentada de ERBB2 comparadas às células que possuem níveis basais do receptor (MACKAY et al., 2003). Esses dados foram condizentes com os resultados observados por dos Santos et al. (2006) utilizando a técnica de SAGE. Análise pela técnica de microarray revelou ainda uma redução da expressão do SPARC nas células que possuem expressão aumentada de ERBB2 após estimulação com HRGß1 (WHITE et al., 2004).

Estudo utilizando células de carcinoma de mama MDA-MB-231 mostrou que altos níveis de SPARC inibem a invasão das células tumorais e não altera a proliferação ou migração (KOBLINSKI et al., 2005). Briggs et al. (2002) demonstraram que a expressão aumentada de SPARC e c-JUN resultam em aumento da migração e invasão das células de carcinoma de mama MCF-7.

Por outro lado, tumores de mama apresentam altos níveis de RNAm e da proteína SPARC comparados ao tecido normal de mama. Os altos níveis de dos transcritos do SPARC foram associados com menor intervalo livre de doença e pior sobrevida global das pacientes (WATKINS et al., 2005).

A função da proteína SPARC na patogênese e no comportamento dos cânceres humano é complexa. O efeito do SPARC na indução ou inibição em diversos tipos de cânceres parece ser dependente do tipo celular, da presença ou não de outras proteínas como metaloproteinases da matriz que clivam o SPARC e da presença do fragmento todo do SPARC ou de fragmentos proteolíticos (SAGE et al., 2003). 


\section{N-myc downstream regulated gene 1 (NDRG1)}

O gene NDRG1, o qual se localiza no cromossomo 8q24.3, é o primeiro dos quatro membros da família NDRG e codifica para uma proteína citoplasmática de 43kDa (QU et al., 2002). A proteína NDRG1 é encontrada principalmente no citoplasma das células, mas também pode ser encontrada associada à membrana e no núcleo (LACHAT et al., 2002). Diferentes níveis de RNAm do NDRG1 foram observados no trato digestivo, sistema imune e urinário, trato respiratório, na pele e em glândulas endócrinas (LACHAT et al., 2002),

A expressão do NDRG1 é modulada em diferentes condições fisiológicas e por estímulos externos como exposição a andrógeno, alta concentração de $\mathrm{Ca}^{+2}$ intracelular, baixas concentrações de glicose e estresse oxidativo (LACHAT et al., 2002). Foi observado em diferentes linhagens de células de câncer de mama um aumento nos níveis de mRNA e da proteína NDRG1 após exposição a níquel (FOTOVATi et al., 2006). Estudo com células de adenocarcinoma hepatocelular mostrou que a hipoxia aumenta a expressão de NDRG1 e esse aumento ocorre através da via de sinalização HIF-1 (SILBOD et al., 2007). Em alguns tipos celulares o aumento da expressão de NDRG1 causada por danos no DNA é dependente da indução da p53 (KURDISTANI et al., 1998; STEIN et al., 2004). A expressão aumentada de NDRG1 em adenocarcinoma cervical foi associada com angiogenese, menor intervalo livre de doença e sobrevida total dos pacientes (NISHIO et al., 2008).

Células tumorais de mama, próstata e cólon apresentam diminuição da expressão de NDRG1 quando comparada às células normais (KURDISTANI et al, 1998; BANDYOPADHYAY et al., 2004). Nas células tumorais de mama e de bexiga a expressão exógena de NDRG1 reduziu o índice de proliferação das células em 70\% (KURDISTANI et al., 1998). Stein et al. (2004) demonstraram que NDRG1 inibiu a proliferação celular de células tumorais metastáticas de pulmão, porém não influenciou a proliferação em células de câncer de cólon não metastáticas.

Por outro lado, os baixos níveis de RNAm e da proteína NDRG1 observado nas células tumorais de mama foi fortemente correlacionado ao pior resultado clínico (BANDYOPADHYAY et al., 2004) e análise imunohistoquímica 
em amostras de pacientes com câncer de mama revelou uma correlação inversa entre a expressão de NDRG1 e o grau histológico (FOTOVATI et al, 2006).

Fotovati et al. (2006) demonstraram que E2 induz a redução da expressão do NDRG1 através de vias dependentes de $\mathrm{ER} \alpha$ em linhagens de células de câncer de mama ER-positivas e em linhagens ER-negativas após a transfecção com vetores contendo $\mathrm{ER} \alpha$.

\section{actinin, alpha 1 (ACTN1)}

A a-actinina é uma proteína que se liga a actina, participa da manutenção do citoesqueleto e é essencial para o ancoramento de proteínas transmembrânicas (CABELLO et al., 2007). O gene ACTN1, localizado no cromossomo 14q22-q24, codifica para uma isoforma de a-actinina não muscular, composta de dois monômeros antiparalelos de 100kDa que se ligam a actina através do N-terminal (OTEY e CARPEN, 2004).

As isoformas de a-actinina interagem com proteínas envolvidas nas vias de transdução de sinal como MEK e ERK (CHRISTERSON et al., 1999). Além disso, foi observado que a ligação de fosfoinositídeos regula o índice de associação e dissociação da a-actinina com os filamentos de actina e que a dinâmica da a-actinina é importante para reorganização do citoesqueleto de actina induzido por PI3K (FRALEY et al., 2005).

Hazan and Norton, (1998), observaram que a perda de adesão células causada pelo tratamento com EGF em células de câncer de mama está à associada com a separação da actina, actinina e vinculina do complexo Ecaderina.

Análise pelas técnicas de SAGE demonstrou redução na expressão do gene ACTN1 nas células com expressão aumentada de ERBB2 comparadas às células que possuem níveis basais do receptor (DOS SANTOS et al., 2006). 


\section{tropomyosin 1 - alpha (TPM1)}

O citoesqueleto de actina possui um importante papel na regulação de processos celulares relacionados à metastase como proliferação celular, apoptose, migração celular e crescimento independente de ancoragem (JAFFE e HALL, 2002). A alteração no citoesqueleto de actina resulta da supressão de várias proteínas como as tropomiosinas (PAWLAK e HELFMAN, 2001). A troponiosina 1 é expressa em células não musculares (RAVAL et al., 2003) e se liga a actina, estabilizando os microfilamentos (PAWLAK e HELFMAN, 2001).

O gene TPM1 foi encontrado menos expresso em células de mama que possuem altos níveis do receptor ERBB2 comparado às células de mama que possuem expressão basal do receptor (DOS SANTOS et al., 2006).

Raval et al. (2003) demonstraram que em tumores de mama invasivo a expressão de TPM1 foi significativamente menor comparada ao tecido normal, independente de parametros como estágio, presença de nódulo, presença de receptor de hormônio, ou presença de ERBB2. A menor expressão de TPM1 está relacionada à desestabilização da arquitetura dos microfilamentos e à resistência das células tumorais à anoikis (RAVAL et al., 2003; BHARADWAJ et al., 2005).

acidic - leucine-rich - nuclear phosphoprotein 32 family, member B (ANP32B)

O gene $A N P 32 B$ foi encontrado mais expresso em células de mama que possuem altos níveis do receptor ERBB2 comparados às células de mama que possuem expressão basal do receptor (DOS SANTOS et al., 2006).

\section{matrin 3 (MATR3)}

O gene MATR3 codifica para uma proteína da matriz nuclear que possui um importante papel na transcrição e interação com outras proteínas da matriz nuclear para formação da rede interna fibrogranular (VALENCIA et al., 2007). 
Este gene foi encontrado mais expresso em células de mama que possuem altos níveis do receptor ERBB2 comparados às células de mama que possuem expressão basal do receptor (DOS SANTOS et al., 2006).

\section{ATPase family, AAA domain containing 4 (ATAD4)}

O gene ATAD4 também conhecido como MCG11242 está localizado no cromossomo 17q21.32 e codifica para uma proteína ainda pouco estudada.

Células de mama que possuem altos níveis do receptor ERBB2 possuem expressão aumentada do gene ATAD4 comparada às células de mama que possuem expressão basal do receptor (DOS SANTOS et al., 2006).

\section{centromere protein $\mathrm{H}$ (CENPH)}

O gene CENPH, o qual se localiza no cromossomo $5 p 15.2$ codifica para uma proteína que está localizada no cinetócoro durante o ciclo celular, e que é importante na organização e função do cinetócoro (SUGATA et al., 1999). Essa proteína, assim como outras proteínas do cinetócoro, é necessária durante a mitose para ligação dos fusos, movimento dos cromossomos e "checkpoint" mitótico (MELLONE et al., 2006).

Foi mostrado que a transfecção das células HEp-2 com siRNA para o gene CENPH causa redução de aproximadamente $50 \%$ no número de células vivas em relação ao controle, indicando que a depleção desse gene causa inibição da proliferação ou aumento da morte celular (ORTHAUS et al., 2006).

O gene $C E N P H$ foi encontrado mais expresso em células de mama que possuem altos níveis do receptor ERBB2 (DOS SANTOS et al., 2006) e em tumores coloretais (TOMONAGA et al., 2005). 
OBJETIVOS 


\section{OBJETIVOS}

Investigar o efeito do EGF na regulação dos genes $S P A R C$, ATAD4, ACTN1, TPM1, NDRG1, MATR3, ANP32B e CENPH, identificados como diferencialmente expressos em células de mama em cultura que apresentam diferentes perfis de expressão de ERBB2.

1- Verificar o efeito do EGF no controle da transcrição dos genes SPARC, ATAD4, ACTN1, TPM1, NDRG1, MATR3, ANP32B e CENPH entre as linhagens de células de mama HB4, C5.2 e SKBr3

2- Analisar a expressão dos transcritos dos genes SPARC, ATAD4, ACTN1, TPM1, NDRG1, MATR3, ANP32B e CENPH nas linhagens de células de mama C5.2 após a supressão da expressão do ERBB2 pela técnica de siRNA. 
MATERIAL E MÉTODOS 


\section{MATERIAL E MÉTODOS}

\subsection{Cultura celular}

Neste estudo foram utilizadas as linhagens celulares HB4a e C5.2 cedidas pelo Dr. Michael J. O'Hare (LICR/UCL Breast Cancer Laboratory, London, UK) e a linhagem SKBr3 cedida pela Dra. Anamaria Aranha Camargo (Instituto Ludwig de Pesquisa sobre o Câncer, São Paulo, Brasil).

A linhagem celular HB4a, derivada de célula luminal da mama, expressa níveis basais do oncogene ERBB2. A linhagem C5.2 é um clone da HB4a, originada pela transcfecção das células HB4a com a construção pJ5E.c-erbB-2 (vetor de expressão contendo a seqüência total de cDNA c-erbB2 obtida da célula de câncer de mama BT474 sob o controle do promotor viral MMTVLTRmouse mammary tumour vírus long terminal repeat) (HARRIS et al., 1999). As células C5.2 possuem 5 cópias da construção pJ5E.c-erbB-2 inseridas no genoma e expressam aproximadamente $10^{6}$ receptores ERBB2 por célula. (HARRIS et al., 1999). A linhagem SKBr3 é derivada de adenocarcinoma de mama, não expressa o receptor de estrógeno, ou seja, ER-negativa e apresenta aumento de expressão de ERBB2, aproximadamente $10^{6}$ receptores por células (LEWIS et al., 1996).

As células HB4a e C5.2 foram cultivadas em meio RPMI-1640 (SIGMA Chemical Corporation, St. Louis - EUA) com antibiótico-antimicótico nas concentrações de $100 \mathrm{U} / \mathrm{ml}$ de penicilina, $100 \mu \mathrm{g} / \mathrm{ml}$ de estreptomicina e 0,25 $\mu \mathrm{g} / \mathrm{ml}$ de fungizona (GIBCO, Gainthersburg - EUA), suplementado com $10 \%$ de soro fetal bovino (GIBCO, Gainthersburg - EUA), $5 \mu \mathrm{g} / \mathrm{ml}$ de insulina (SIGMA Chemical Corporation, St. Louis - EUA), $5 \mu \mathrm{g} / \mathrm{ml}$ de hidrocortisona (SIGMA Chemical Corporation, St. Louis - EUA) e mantidas em estufa a $37^{\circ} \mathrm{C}$ sob atmosfera de $5 \%$ de $\mathrm{CO}_{2}$.

As células SKBr3 foram cultivadas em meio RPMI-1640 com antibióticoantimicótico nas concentrações de $100 \mathrm{U} / \mathrm{ml}$ de penicilina, $100 \mu \mathrm{g} / \mathrm{ml}$ de estreptomicina e $0,25 \mu \mathrm{g} / \mathrm{ml}$ de fungizona, suplementado com $10 \%$ de soro fetal bovino, 2 mM de L-glutamina (Invitrogen Life Technologies, Califórnia - EUA). e mantidas em estufa a $37{ }^{\circ} \mathrm{C}$ sob atmosfera de $5 \%$ de $\mathrm{CO}_{2}$. 
As células HB4a (passagem 40) e C5.2 (passagem 53) foram mantidas em meio RPMI1640, com antibiótico-antimicótico nas concentrações de $100 \mathrm{U} / \mathrm{ml}$ de penicilina, $100 \mu \mathrm{g} / \mathrm{ml}$ de estreptomicina e $0,25 \mu \mathrm{g} / \mathrm{ml}$ de fungizona, suplementado com $0,1 \%$ de soro fetal bovino e $5 \mu \mathrm{g} / \mathrm{ml}$ de hidrocortisona por 48 horas antes do tratamento. E as células SKBr3 (passagem 38) foram mantidas 48 horas em meio RPMl1640, com antibiótico-antimicótico nas concentrações de $100 \mathrm{U} / \mathrm{ml}$ de penicilina, $100 \mu \mathrm{g} / \mathrm{ml}$ de estreptomicina e 0,25 $\mu \mathrm{g} / \mathrm{ml}$ de fungizona, suplementado com $0,1 \%$ de soro fetal bovino e $2 \mathrm{mM}$ de $\mathrm{L}$ glutamina.

Em seguida as células foram tratadas com 30,60 e $100 \mathrm{ng} / \mathrm{ml}$ de EGF (SIGMA Chemical Corporation, St. Louis - EUA) durante 2, 6 e 24 horas ou com $60 \mathrm{ng} / \mathrm{ml}$ de heregulina (SIGMA Chemical Corporation, St. Louis - EUA) durante 2 e 24 horas.

\subsection{Extração de RNA - adaptado de Chomczynski e Sacchi (1987)}

Para a extração do RNA a monocamada de células aderida ao frasco de cultura foi lavada três vezes com solução PBS. Retirou-se totalmente a solução de PBS e adicionou-se $750 \mu \mathrm{l}$ de solução D gelada (4 M de lisotiocianato de guanidina, $25 \mathrm{mM}$ de citrato de sódio, $\mathrm{pH} 7,0,0,5 \%$ de sarcosil, $0,1 \mathrm{M}$ de $\beta$ mercaptoetanol). Agitou-se por 20 segundos e, em seguida, a solução foi transferida para um microtubo de $2 \mathrm{ml}$. Adicionou-se $75 \mu \mathrm{l}$ de acetato de sódio $2 \mathrm{M}, \mathrm{pH}$ 4,0; $750 \mu \mathrm{l}$ de fenol pH 5,0-6,0; e 187,5 $\mu \mathrm{l}$ de clorofórmio-álcool isoamílico (49:1), homogeneizando por inversão após a adição de cada solução. A suspensão final foi agitada vigorosamente por 10 segundos e deixada em banho de gelo por 15 minutos. Após este período, as amostras foram centrifugadas por 30 minutos a $10.000 \mathrm{rpm}$ a $4{ }^{\circ} \mathrm{C}$. A fase aquosa foi transferida para um novo tubo e precipitada com $1 \mathrm{ml}$ de isopropanol a $-20{ }^{\circ} \mathrm{C}$ por 16 horas. Após este período, centrifugou-se a 10.000 rpm por 20 minutos e o precipitado resultante foi seco e dissolvido em $150 \mu \mathrm{l}$ de solução $D$, transferido para um novo microtubo de $1,5 \mathrm{ml}$ e precipitado com $150 \mu \mathrm{l}$ de isopropanol por 16 hora a $-20{ }^{\circ} \mathrm{C}$. Centrifugou-se por 20 minutos a $10.000 \mathrm{rpm}$ a $4{ }^{\circ} \mathrm{C}$ e após desprezar o sobrenadante foi adicionado $150 \mu \mathrm{l}$ de etanol $75 \%$. 
Após centrifugação por 10 minutos a $10.000 \mathrm{rpm}$ a $4{ }^{\circ} \mathrm{C}$, o sobrenadante foi desprezado e o pellet dissolvido em água livre de RNase.

A concentração do RNA extraído foi determinada por leitura espectrofotométrica a $260 \mathrm{~nm}$ e a qualidade (integridade) do material foi analisada em gel de agarose a $1 \%$, contendo $10 \%$ de MOPS e $5,1 \%$ de formaldeído. Aplicou-se no gel $1 \mu \mathrm{l}$ de amostra, $4 \mu \mathrm{l}$ do tampão de aplicação (52,8\% de formamida deionizada, $10,5 \%$ de MOPS, $16,9 \%$ de formaldeído, $7,0 \%$ de glicerol e $5,6 \%$ de bromofenol blue) e $1 \mu \mathrm{l}$ de brometo de etídio (SIGMA Chemical Corporation, St. Louis - EUA).

\subsection{Tratamento com DNase}

Doze microgramas de RNA total foram tratados com a enzima DNAsel RNAse free $1 \mathrm{U} / \mu \mathrm{l}$ (Promega) por 60 minutos a $37{ }^{\circ} \mathrm{C}$. Após esse período, 0 RNA foi precipitado com 5,2 $\mu \mathrm{l}$ de acetato de sódio $2 \mathrm{M}$, pH 4,6 e 125,0 $\mu \mathrm{l}$ de etanol absoluto a $-20^{\circ} \mathrm{C}$ durante 16 horas. Em seguida centrifugou-se por 30 minutos a $4^{\circ} \mathrm{C}$ e $10.000 \mathrm{rpm}$ e após desprezar o sobranadante foi adicionado $200 \mu \mathrm{l}$ de etanol 75\%. Centrifugou-se novamente por 20 minutos, $10.000 \mathrm{rpm}$ a $4^{\circ} \mathrm{C}$ e em seguida o sobrenadante foi desprezado. Após secagem do pellet, $\mathrm{O}$ RNA foi ressuspendido em $50 \mu \mathrm{l}$ de $\mathrm{H}_{2} \mathrm{O}$.

\subsection{Síntese de cDNA}

Alíquotas de $10 \mu \mathrm{g}$ RNA total, obtidos das células em cultura, foram utilizadas para a síntese de cDNA utilizando-se o High Capacity cDNA Archive Kit (Applied Biosystems). Em cada reação adicionou-se $1 \mathrm{U} / \mu \mathrm{l}$ de RNAseOUT Ribonuclease Inhibitor (Invitrogen Life Technologies, Califórnia - EUA). 


\subsection{RT-PCR (Reverse Trancriptase-Polymerase Chain Reaction)}

Os cDNAs sintetizados foram analisados por PCR utilizando-se os oligonucleotídeos para os genes $\beta$-2-microglobulina e GAPDH para verificação de sua qualidade e integridade. O volume total de cada reação foi de $25 \mu \mathrm{l}$, utilizando-se 2,5 $\mu$ l do cDNA (diluído1:10), a concentração adequada de cada oligonucleotídeo, $1250 \mu \mathrm{M}$ de dNTPs (Amersham Biosciences, Nova Jersey EUA), 2,5 $\mu$ l de tampão (500 nM de $\mathrm{KCl}, 100 \mathrm{nM}$ de Tris HCL, $\mathrm{pH}$ 8,3, $1 \mathrm{mg} / \mathrm{ml}$ de gelatinae e $15 \mathrm{mM}$ de $\mathrm{MgCl}_{2}$ ) e $125 \mathrm{U}$ de taq DNA polimerase (Invitrogen Life Technologies, Califórnia - EUA). As amostras foram amplificadas no termociclador (PCR System 9700 - Applied Biosystems) por 35 ciclos (cada ciclo possue 1 minuto de desnaturação a $95^{\circ} \mathrm{C}, 1$ minuto de anelamento a 55 $\stackrel{\circ}{\circ}$ e 1 minuto de extensão a $72 \stackrel{\circ}{ } \mathrm{C}$ ) e ao final destes ciclos 5 minutos de extensão a $72 \stackrel{\circ}{\circ}$.

\subsection{PCR em Tempo Real}

A quantificação relativa dos transcritos diferencialmente expressos foi realizada por PCR em tempo real. A PCR em tempo real é uma técnica de coleta de dados que ocorre durante a reação de PCR, portanto combina amplificação e detecção em um único passo. Para isso são utilizados fluoróforos que possibilitam correlacionar a concentração do produto da PCR com a intensidade da fluorescência.

A reação de PCR em tempo real pode ser dividida em 4 fases: linear, início da exponencial, fase log-linear ou exponencial e fase platô. Durante a fase linear a PCR está começando e há emissão de pouca fluorescência gerando o "background". No início da fase exponencial a quantidade de fluorescência alcança um threshold, onde a fluorescência é significativamente maior que o "background" (WONG e MEDRANO, 2005). O ciclo no qual isso ocorre é chamado de Ct (Applied Biosystems, Foster City - CA). A reação de PCR alcança sua amplificação ótima na fase log-linear quando o produto de PCR dobra a cada ciclo. E por fim, a fase platô quando os componentes da reação tornam-se limitados (WONG e MEDRANO, 2005). 
Para a reação de PCR em tempo real foram utilizados os cDNAs provenientes das amostras de RNA das células nos diferentes tratamentos, oligonucleotídeos específicos desenhados para os transcritos a serem analisados e o kit SYBR Green PCR Reagent (Applied Biosystems, Foster City - CA) de acordo com as instruções do fabricante. O corante SYBR Green emite fluorescência quando intercalado à dupla fita de DNA. Assim a intensidade de fluorescência aumenta proporcionalmente a concentração de dupla fita de DNA. A amplificação e detecção dos fragmentos amplificados foram feitas utilizando-se o ABI 5700 Detection System (Perkin Elmer).

As condições de ciclagem para as reações de PCR foram: $50{ }^{\circ} \mathrm{C}$ por 2 minutos, $95{ }^{\circ} \mathrm{C}$ por 10 minutos e 40 ciclos de $95{ }^{\circ} \mathrm{C}$ por 15 segundos e $55{ }^{\circ} \mathrm{C}$ por 1 minuto. As reações foram feitas em duplicata para cada amostra e contendo em cada placa o gene utilizado como referência.

Para determinar o gene de referência apropriado para as análises de PCR em tempo real, foi analisada a expressão de quatro genes constitutivos: GAPDH, HPRT1, $\beta$-actina e RPL13A. A determinação do gene mais estável foi realizada através do programa GeNorm VBA Applet for Microsoft Excel. Através dos valores de estabilidade gerados pelo programa foi definido como gene de referência o GAPDH.

A expressão relativa é calculada por $2^{-\Delta \Delta C t}$ onde:

$\mathrm{Ct}=$ ciclo de início de detecção do transcrito

$\Delta \mathrm{Ct}=\mathrm{Ct}$ do gene de interesse menos o $\mathrm{Ct}$ do gene referência

$\Delta \Delta \mathrm{Ct}=\Delta \mathrm{Ct}$ médio da amostra de interesse menos $\Delta \mathrm{Ct}$ médio da amostra referência.

Para a análise de expressão gênica relativa nas células tratadas com EGF, utilizamos as células mantidas em soro normal como referência.

\subsection{Ensaio de RNAi (siRNA)}

A interferência de RNA na supressão ou silenciamento gênico vem sendo utilizada no estudo funcional de diversos genes em diferentes organismos. Em células de mamíferos a utilização de pequenas duplas fitas de 
RNAs (siRNA) de 21-23 nucleotídeos são apropriadas pois evita a inibição inespecífica de tradução de proteínas pela proteína quinase $R$ (PKR) ou RNAse L (HANNON, 2002).

Para o experimento usamos Lipofectamina ${ }^{\mathrm{TM}}$ 2000, um mix de siRNA para o gene ERBB2 e RNAi controle negativo (Invitrogen Life Technologies, Califórnia - EUA).

Para o experimento de siRNA as células C5.2 foram mantidas em meio RPMI-1640, em estufa a $37{ }^{\circ} \mathrm{C}$ sob atmosfera de $5 \%$ de $\mathrm{CO}_{2}$ até atingirem a confluência de $50 \%$. Inicialmente $5 \mu \mathrm{l}$ de Lipofectamina ${ }^{\mathrm{TM}} 2000$ é diluída em $245 \mu \mathrm{l}$ de meio Opti-MEM sem antibiótico e após homogeinização incubou-se 5 minutos a temperatura ambiente. Em seguida foi adicionado à Lipofectamina ${ }^{\mathrm{TM}}$ 2000 diluída $50 \mathrm{nM}$ de siRNA diluídos em $250 \mu \mathrm{l}$ de meio Opti-MEM sem antibiótico, o mesmo foi feito para o siRNA controle negativo. A mistura foi incubada por 20 minutos a temperatura ambiente e em seguida adicionada às placas de 6 poços contendo $2 \mathrm{ml}$ de meio RPMl1640. Após 6 horas na estufa a $37{ }^{\circ} \mathrm{C}$ sob atmosfera de $5 \%$ de $\mathrm{CO}_{2}$ foi adicionado $10 \%$ de soro, $5 \mu \mathrm{g} / \mathrm{ml}$ de insulina e $5 \mu \mathrm{g} / \mathrm{ml}$ de hidrocortisona, e após 72 horas extraiu-se o RNA e as proteínas. A confirmação do silenciamento dos receptores ERBB2 foi realizada por Real Time PCR e por Western-blot.

\subsection{Extração de proteínas}

Para a extração de proteínas a monocamada de células foi lavada três vezes com solução PBS. Retirou-se a solução de PBS e foi adicionado $2 \mathrm{ml}$ de PBS-EDTA, com auxilio de rodinhos as células foram retiradas da garrafa de cultura e colocadas em um microtubo. Centrifugou-se por 2 minutos a temperatura ambiente e $2.000 \mathrm{rpm}$ e após desprezar o sobranadante o pellet

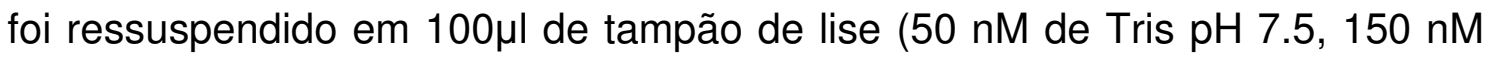
de $\mathrm{NaCl}, 5 \mathrm{mM}$ de EDTA pH 8, $\%$ de triton, $1 \mathrm{mM}$ de $\mathrm{Na}_{3} \mathrm{VO}_{4}, 2 \mu \mathrm{g} / \mathrm{ml}$ de aprotinina, $1 \mathrm{mM}$ de PMSF e $1 \mathrm{\mu g} / \mathrm{ml}$ de leupeptina). Após 15 minutos a $4 \stackrel{\circ}{\circ} \mathrm{C}$ centrifugou-se por 15 minutos a $4 \stackrel{\circ}{\circ} \mathrm{C}$ e $2.000 \mathrm{rpm}$. O sobrenadante foi transferido para um novo microtubo e armazenado a $-20 \stackrel{\circ}{\circ}$. 


\subsection{Western-blot}

A quantificação das proteínas foi realizada pelo método de Bradford. Para a eletroforese foi realizada com $15 \mu \mathrm{g}$ do extrato protéico, $6 \mu \mathrm{l}$ de tampão Laemmli e $\mathrm{H}_{2} \mathrm{O}$ q.s.p. $15 \mu \mathrm{l}$. Em seguida as amostras foram aquecidas a $95{ }^{\circ} \mathrm{C}$ durante 5 minutos e aplicadas no gel.

A eletroforese foi realizada em gel de empilhamento SDS-PAGE 4\% e gel de separação de proteínas SDS-PAGE 7,5\%. O tampão de corrida utilizado foi o Tris-Glicina 10X com $10 \%$ de SDS. A corrida eletroforética foi realizada a $70 \mathrm{~V}$ por 20 minutos e em seguida 2 horas a 100V. Após a corrida, as proteínas foram transferidas para a membrana de nitrocelulose (Pierce, Rockford, IL) utilizando tampão de transferência (tampão Tris-Glicina 10X contendo $2 \%$ de metanol), o aparato Trans-Blot Semi-Dry (Bio Rad Laboratories, Califórnia EUA) com corrente elétrica de $15 \mathrm{~V}$ por 30 minutos.

Após a transferência a membrana foi incubada, sob agitação, em solução de leite em pó desnatado 5\% (diluído em tampão Tris-tween) durante 1 hora à temperatura ambiente para bloqueio dos sítios inespecíficos. A seguir, a membrana foi lavada três vezes por 10 minutos com tampão Tris-tween (TBS-t) e incubada, sob agitação por $15 \mathrm{~h}$ a $4{ }^{\circ} \mathrm{C}$, com o anticorpo primário anti-ERBB2 (Chemicon International) em seguida, 1 hora com anticorpo para $\beta$-actina e por fim, 1 hora com anticorpo secundário anti-mouse (todos os anticorpos foram usados na diluição 1:1000 em solução de albumina 3\%.).

Entre as incubações a membrana foi novamente lavada por três vezes de 10 minutos com TBS-t. A detecção das proteínas foi realizada por reação quimioluminescente seguida da exposição em filme de raio-X (Kodak Biomax XAR) por 10 segundos a temperatura ambiente.

\subsection{Análise estatística}

As diferenças entre os valores dos três experimentos independentes de PCR em tempo real foram analisadas utilizando o teste $t$ de Student. Foram consideradas estatisticamente significativas as diferenças com $p<0,05$. 


\section{RESULTADOS}

Este estudo teve como objetivo analisar o efeito do EGF na regulação dos transcritos de genes previamente identificados como diferencialmente expressos em células de mama em cultura apresentando diferentes níveis de expressão de ERBB2. Foram utilizadas as células de mama HB4a, que apresenta níveis basais de ERBB2 e as células de mama C5.2 e SKBr3 que apresentam altos níveis desse receptor. Após os tratamentos com EGF, HRG e após a transfecção com siRNA o RNA total foi extraído como descrito nos material e métodos. A qualidade do RNA total extraído foi verificada em gel de agarose $1 \%$ (Figura 3). O RNA total extraído foi tratado com DNase I para posterior síntese dos cDNAs. A integridade e qualidade dos cDNas sintetizados foram avaliadas pela reação de RT-PCR para os genes GAPDH e $\beta$-microglobulina (Figura 4). Em seguida os cDNas foram utilizados para a realização da reação de PCR em tempo real. A qualidade e especificidade das reações foram verificadas pela curva de amplificação e pelo gráfico de dissociação (Figura 5).

4.1 Análise da expressão dos transcritos ERBB2, ATAD4, MATR3, NDRG1, ANP32B, ACTN1, CENPH, TPM1 e SPARC nas linhagens HB4a, C5.2 e SKBr3

Inicialmente, verificamos o perfil de expressão dos transcritos ERBB2 nas linhagens HB4a, C5.2 e SKBr3 mantidas em meio com 10\% de soro fetal bovino (FBS). Como pode ser observado na figura $6 a$, as células $\mathrm{C} 5.2$ e $\mathrm{SKBr} 3$ apresentam níveis de expressão dos transcritos ERBB2 34 e 56 vezes, respectivamente, maiores que as células HB4a. A diferença de expressão dos transcritos ERBB2 entre as células HB4a, C5.2 e SKBr3 foi confirmada por Western Blot (Figura 6B).

A figura 7 mostra a expressão relativa dos transcritos dos genes ATAD4, MATR3, NDRG1, ANP32B, ACTN1, CENPH, TPM1 e SPARC nas células HB4a, C5.2 e SKBr3 mantidas meio com 10\% de FBS. As células C5.2 e SKBr3 apresentaram expressão aumentada dos transcritos do ATAD4 (35 \pm 9 , 
$p=0,003 ; 9,6 \pm 2,6, p=0,004$, respectivamente) e do NDRG1 $(1,8 \pm 0,5, p=0,06$; $2,8 \pm 0,4, p=0,001$, respectivamente) comparadas as células HB4a. As células C5.2 e SKBr3, comparadas as células HB4a, apresentaram expressão reduzida dos transcritos do MATR3 $(0,5 \pm 0,3, p=0,06 ; 0,79 \pm 0,4, p=0,4$, respectivamente), ANP32B $(0,84 \pm 0,16, p=0,1 ; 0,56 \pm 0,1, p=0,001$, respectivamente), do ACTN1 $(0,69 \pm 0,2, \quad p=0,07 ; \quad 0,05 \pm 0,006, \quad p=0,0001$, respectivamente), do CENPH $(0,5 \pm 0,08, \quad p=0,0005 ; 0,6 \pm 0,2, p=0,04$, respectivamente). Comparadas às células HB4a, às células C5.2 mostraram aumento dos transcritos do TPM1 $(1,25 \pm 0,3, p=0,27)$, enquanto as células $\mathrm{SKBr} 3$ mostraram redução significativa dos mesmos transcritos $(0,77 \pm 0,07, p=0,04)$. Os transcritos do $S P A R C$ foram encontrados reduzido nas células C5.2 comparadas as células HB4a $(0,59 \pm 0,2$, $p=0,06$ ) e foram indetectáveis nas células SKBR3.

\subsection{Curva de concentração versus tempo de exposição ao EGF}

Para avaliar o efeito do EGF na expressão dos genes alvos deste estudo, as células HB4a, C5.2 e SKBr3 foram tratadas com 30, 60 e 100ng/ml de EGF durante 2, 6 e 24 horas.

Os resultados dessa análise, ilustrados na figura 8 , mostraram aumento significativo na expressão dos transcritos do ATAD4 nas células HB4a após a redução do FBS $(2,86 \pm 0.67 ; p=0,009)$, o mesmo efeito não foi observado nas células $\mathrm{C} 5.2$ e SKBr3. As células HB4a tratadas com EGF apresentaram redução significativa na expressão dos transcritos do ATAD4 em todas as condições testadas comparadas às células mantidas em $0,1 \%$ de FBS, sendo as reduções mais significativas após 24 horas de tratamento (média e desvio padrão das concentrações de 30,60 e $100 \mathrm{ng} / \mathrm{ml}$, respectivamente, $2,86 \pm 0.67$ vs $0,36 \pm 0,09,2,86 \pm 0.67$ vs $0,39 \pm 0,1$ e $2,86 \pm 0.67$ vs $0,31 \pm 0,09 ; p=0,003$ ).

Assim como as células $\mathrm{HB} 4 \mathrm{a}$, as células $\mathrm{C} 5.2$ tratadas com EGF também apresentaram diminuição significativa dos transcritos do ATAD4 nas condição testadas comparadas às células mantidas em $0,1 \%$ de FBS, exceto após o tratamento com $30 \mathrm{ng} / \mathrm{ml}$ durante 6 horas, onde a redução não foi significativa provavelmente devido ao grande desvio padrão. Após os tratamentos com $30 \mathrm{ng} / \mathrm{ml}$ de EGF durante 2 horas, $60 \mathrm{ng} / \mathrm{ml}$ durante 2 e 6 horas 
e $100 \mathrm{ng} / \mathrm{ml}$ durante os três tempos testados, as células SKBr3, comparadas às células mantidas em $0,1 \%$ de FBS, apresentaram redução significativa do ATAD4. Nas células $\mathrm{C} 5.2$ e SKBr3 as maiores diminuição dos transcritos do ATAD4 ocorrem com os tratamentos de 2 horas (valores da média e do desvio padrão nas células C5.2 após 2 horas de tratamento com 30, 60 e 100ng/ml de EGF, $0,830 \pm 0.14$ vs $19 \pm 0,01 ; 0,830 \pm 0.14$ vs $0,144 \pm 0,02 ; 0,830 \pm 0.14$ vs $0,18 \pm 0,07 ; p=0,002$ e os valores nas células $\mathrm{SKBr} 3$ foram $1,09 \pm 0,29$ vs $0,31 \pm 0,05 ; 1,09 \pm 0,29$ vs $0,27 \pm 0,05 ; 1,09 \pm 0,29$ vs $0,23 \pm 0,07 ; p=0,01$, respectivamente).

Como pode ser observado na figura 9, a redução do FBS aumentou significativamente a expressão dos transcritos do NDRG1 nas células C5.2 e SKBr3 $(1,29 \pm 0,08 ; p=0,004$ e $1,77 \pm 0,09 ; p=0,001$, respectivamente). Nas células HB4a houve aumento na expressão dos transcritos do NDRG1 após a redução do FBS, porém esse aumento não foi estatisticamente significativa devido ao grande desvio padrão. Os tratamentos com 30, 60 e 100ng/ml de EGF durante 6 e 24 horas reduziram a expressão do NDRG1 nas células HB4a comparadas às células mantidas em $0,1 \%$ de FBS, porém apenas os tratamentos durante 24 horas foram estatisticamente significativos $(3,13 \pm 1,58$ vs $0,26 \pm 0,11 ; 3,13 \pm 1,58$ vs $0,27 \pm 0,11 ; 3,13 \pm 1,58$ vs $0,30 \pm 0,13 ; p=0,035)$. Nas células SKBr3 tratadas com EGF comparadas às células mantidas em $0,1 \%$ de FBS observou-se diminuição significativa dos transcritos do NDRG1 apenas com 2 horas de tratamento $(1,77 \pm 0,09$ vs $1,36 \pm 0,16 ; 1,77 \pm 0,09$ vs $1,06 \pm 0,16$; $1,77 \pm 0,09$ vs $1,18 \pm 0,25 ; p=0,02$ ). Ao contrário da linhagem HB4a e SKBr3, as células C5.2 apresentaram aumento significativo na expressão do NDRG1 comparadas às células mantidas em $0,1 \%$ de FBS após 6 horas de tratamento com 30 e $100 \mathrm{ng} / \mathrm{ml}$ de EGF $(1,29 \pm 0,08$ vs $2,36 \pm 0,58 ; p=0,035$ e 1,29 $\pm 0,08$ vs $1,96 \pm 0,4 p=0,048$, respectivamente) e após 24 horas de tratamento com $60 \mathrm{ng} / \mathrm{ml}$ de EGF $(1,29 \pm 0,08$ vs $2,07 \pm 0,27 ; p=0,009)$.

Baseado em dados da literatura nos quais se avaliou o efeito do EGF sob a expressão de outros transcritos e na análise da expressão dos transcritos do ATAD4 e do NDRG1 após a exposição ao EGF definiu-se que as demais análises seriam realizadas após o tratamento com $60 \mathrm{ng} / \mathrm{ml}$ de EGF. Portanto, os transcritos dos genes ANP32B, MATR3, SPARC, ACTN1 e TPM1 foram 
analisados nas células HB4a, C5.2 e SKBr3 após o tratamento com $60 \mathrm{ng} / \mathrm{ml}$ de EGF durante 2, 6 e 24 horas.

Como mostrado na figura 10, não houve alteração significativa na expressão dos transcritos do $A N P 32 B$ após a redução de FBS e após os tratamentos com EGF na linhagem HB4a. Nas linhagens celulares C5.2 e SKBr3 ocorreu redução na expressão dos transcritos do ANP32B após 6 e 24 horas de tratamento comparadas às células mantidas em $0,1 \%$ de FBS mas não foi estatisticamente significativo.

A redução de FBS e os tratamentos com $60 \mathrm{ng} / \mathrm{ml}$ de EGF não alteraram significativamente a expressão dos transcritos do MATR3 nas células HB4a (Figura 11). As células C5.2 apresentaram aumento significativo na expressão do MATR3 após ao diminuição de FBS $(2,52 \pm 0,9 ; p=0,044)$. Nestas células, os tratamentos com EGF durante 6 e 24 horas reduziram significativamente a expressão do MATR3 em relação às células mantidas em $0,1 \%$ de FBS $(2,52 \pm 0,9$ vs $0,37 \pm 0,14 ; p=0,016$ e $2,52 \pm 0,9$ vs $0,38 \pm 0,08 ; p=0,015$, respectivamente). $O$ tratamento com EGF após 2 horas nas células $C 5.2$ assim como após 6 horas nas células $\mathrm{SKBr} 3$ diminuíram a expressão dos transcritos do MATR3 comparadas ás células mantidas em 0,1\% de FBS, mas não foram estatisticamente significativo.

Como ilustrado na figura 12 , a redução de FBS não alterou significativamente a expressão do ACTN1 nas células HB4a, enquanto nas células $\mathrm{C} 5.2$ e $\mathrm{SKBr} 3$ ocorreu uma diminuição significativa dos transcritos $(0,86 \pm 0,04 ; p=0,005$ e $0,88 \pm 0,02 ; p=0,012$, respectivamente). Os tratamentos das células HB4a com EGF durante 2 e 6 horas resultaram em aumento significativo na expressão dos transcritos do $A C T N 1$ comparadas às células mantidas em $0,1 \%$ de FBS $(0,79 \pm 0,19$ vs $1,7 \pm 0,38 ; p=0,020$ e $0,79 \pm 0,19$ vs $2,75 \pm 1,03 ; p=0,033$, respectivamente). Após 24 horas de tratamento com EGF, apenas as células $\mathrm{C} 5.2$ apresentaram aumento significativo destes transcritos comparadas às células mantidas em $0,1 \%$ de FBS $(0,86 \pm 0,04$ vs $1,68 \pm 0,05$; $p=0,0001$ ).

A expressão dos transcritos do TPM1 não foi alterada de maneira significativa nas células $\mathrm{C} 5.2$ e SKBr3 após a redução de FBS ou após os tratamentos com EGF (Figura 13). Nas células HB4a houve aumento na expressão do TPM1 após os tratamentos com EGF por 2 e 6 horas 
comparadas às células mantidas em $0,1 \%$ de FBS, porém apenas o tratamento durante 2 horas foi estatisticamente significativo $(0,99 \pm 0,24$ vs $12 \pm 0,38$; $p=0,012$ ).

A redução de FBS e o tratamento com EGF durante 2 horas nas células HB4a e C5.2 alteraram pouco a expressão dos transcritos do CENPH comparados às células mantidas em $0,1 \%$ de FBS (Figura 14). Após 6 e 24 horas de tratamento com EGF as células HB4a e SKBr3 mostraram redução na expressão dos transcritos do $C E N P H$, porém não foi estatisticamente significativa. As células C5.2 apresentaram aumento na expressão dos transcritos do CENPH após a redução de FBS. Os tratamentos com EGF durante 2, 6 e 24 horas nestas células reduziram a expressão destes transcritos, porém não foram estatisticamente significativos.

A redução de FBS nas células HB4a aumentou a expressão dos transcritos do SPARC (Figura 15), mas devido ao grande desvio padrão o aumento não foi estatisticamente significativo. Nas células C5.2 a redução de FBS aumentou significativamente a expressão destes transcritos $(1,8 \pm 0,27$; $p=0,007)$. Após os tratamentos com EGF durante 6 e 24 horas as células HB4a mostraram redução dos transcritos do SPARC comparadas às células mantidas em $0,1 \%$ de FBS, porém apenas a redução após 24 horas foi estatisticamente significativa $(1,8 \pm 0,53$ vs $0,51 \pm 0,06 ; p=0,015)$. Nas células C5.2 pode se observar redução dos transcritos do SPARC já após 2 horas de tratamento comparadas às células mantidas em $0,1 \%$ de FBS, mas não foi estatisticamente significativo devido ao tamanho do desvio padrão. Após 6 e 24 horas de tratamento com EGF as diminuições na expressão dos transcritos do $S P A R C$ foram estatisticamente significativa $(1,8 \pm 0,27$ vs $0,78 \pm 0,19 ; p=0.020$ e $1,8 \pm 0,27$ vs $0,70 \pm 0,37 ; p=0.031$, respectivamente). A expressão do $S P A R C$ não foi detectada nas células SKBr3 mantidas em soro normal, em $0,1 \%$ de FBS e nas células tratadas com EGF.

O efeito do EGF nas células HB4a, que possuem expressão basal dos receptores ERBB2, foram diferentes dos efeitos observados nas células $C 5.2 \mathrm{e}$ $\mathrm{SKBr} 3$, que possuem altos níveis do receptor. Algumas hipóteses poderiam explicar essa diferença nas respostas ao EGF, como o possível efeito constitutivo do ERBB2 nas células $\mathrm{C} 5.2$ e SKBr3 ou diferenças nos níveis de expressão de EGFR nessas células. Por esse motivo analisamos por PCR em 
tempo real a expressão dos transcritos do EGFR nas três linhagens. Os resultados desta análise, ilustrados na figura 16, mostram menor expressão dos transcritos do EGFR nas células $\mathrm{C} 5.2$ e $\mathrm{SKBr} 3$ comparadas às células HB4a. As células HB4a possuem mais receptores EGFR que as células $C 5.2 \mathrm{e}$ $\mathrm{SKBr} 3$, o que poderia explicar a melhor resposta das células HB4a pois nestas células haveria maior formação de homodímeros EGFR-EGFR e heterodímeros EGFR-ERBB2.

\subsection{Tratamento das células HB4a e SKBr3 com Heregulina $\beta 1$}

As células HB4a e SKBr3 foram tratadas com $60 \mathrm{ng} / \mathrm{ml}$ de heregulina $\beta 1$ (HRG) durante 2 e 24 horas.

As células HB4a tratadas com HRG durante 2 e 24 horas apresentaram redução significativa na expressão dos transcritos do ATAD4 comparadas às células mantidas em $0,1 \%$ de FBS $(2,21 \pm 0,25$ vs $0,72 \pm 0,12 ; p=0,0008$ e $2,21 \pm 0,25$ vs $1,07 \pm 0,53 ; p=0,02$, respectivamente). As células $\mathrm{SKBr} 3$ mostraram redução significativa na expressão dos transcritos do ATAD4 após o tratamento com HRG durante 2 horas comparadas as células mantidas em $0,1 \%$ de FBS $(0,93 \pm 0,05$ vs $0,27 \pm 0,13 ; p=0,001)$ e aumento destes transcritos após o tratamento de 24 horas, porém não foi estatisticamente significativo (Figura 9).

O tratamento com HRG durante 24 horas reduziu a expressão dos transcritos do NDRG1 nas células HB4a comparadas às células mantidas em $0,1 \%$ de FBS, mas não foi estatisticamente significativo. Comparadas às células SKBr3 mantidas em $0,1 \%$ de FBS o tratamento com HRG durante 2 horas reduziu significativamente a expressão dos transcritos do NDRG1 $(2,96 \pm 0,74$ vs $1,21 \pm 0,75 ; p=0,045)$ e após 24 horas de tratamento foi observado aumento significativo destes transcritos $(2,96 \pm 0,74$ vs $8,00 \pm 2,67$; $p=0,034$ ) (Figura 11).

As células HB4a tratadas com HRG durante 24 horas apresentaram um aumento na expressão dos transcritos do $A N P 32 B$ em relação às células $\mathrm{HB} 4 \mathrm{a}$ mantidas em $0,1 \%$ de FBS, mas foi estatisticamente significativo. As células SKBr3 tratadas com HRG durante 2 horas apresentaram redução significativa 
dos transcritos do $A N P 32 B$ comparadas às células mantidas em $0,1 \%$ de FBS $(0,42 \pm 0,07$ vs $0,17 \pm 0,02 ; p=0,004)$ (Figura 13).

As células HB4a tratadas com HRG durante 2 e 24 horas apresentaram aumento na expressão dos transcritos do MATR3 comparadas às células mantidas em $0,1 \%$ de FBS, sendo significativo apenas com 24 horas de tratamento $(1,04 \pm 0,09$ vs $3,24 \pm 0,11 ; p=0,002)$. Diferente do observado no experimento com EGF, a redução de FBS nas células $\mathrm{SKBr3}$ diminuiu significativamente a expressão dos transcritos do $\operatorname{MATR3}(0,36 \pm 0,13 ; p=0,001)$. Nas células SKBr3 o tratamento com HRG durante 24 horas mostrou aumento na expressão do MATR3 em relação às células mantidas em 0,1\% de FBS, porém não foi estatisticamente significativo (Figura 15).

Como ilustrado na figura 17 não houve alteração significativa na expressão dos transcritos do ACTN1 nas células HB4a mantidas em $0,1 \%$ de FBS ou após os tratamentos com HRG. A expressão dos transcritos do ACTN1 aumentou significativamente nas células SKBr3 após o tratamento com HRG durante 24 horas comparadas às células mantidas em $0,1 \%$ de FBS $(0,54 \pm 0,14$ vs $1,19 \pm 0,38 ; p=0,05)$.

Não foram observadas alterações significativas na expressão dos transcritos do TPM1 nas células HB4a tratadas com HRG comparas às células mantidas em $0,1 \%$ de FBS. Nas células SKBr3 após o tratamento com HRG durante 24 horas comparadas às células mantidas em 0,1\% de FBS observouse aumentou significativamente dos transcritos do TPM1 $(0,49 \pm 0,01$ vs $0,85 \pm 0,17 ; p=0,02$ ) (Figura 19).

Não houve alteração significativa na expressão dos transcritos do CENPH nas células HB4a mantidas em $0,1 \%$ de FBS ou após os tratamentos com HRG. Nas células SKBr3 após o tratamento com HRG durante 2 horas foi observada redução dos transcritos do $C E N P H$ comparadas às células mantidas em $0,1 \%$ de FBS (Figura 21).

Como observado na figura 23 não houve alteração significativa na expressão dos transcritos do SPARC nas células HB4a mantidas em $0,1 \%$ de FBS ou após os tratamentos com HRG. A expressão do SPARC não foi detectada nas células SKBr3 mantidas em soro normal ou mantidas em $0,1 \%$ de FBS e nas células tratadas com HRG. 


\subsection{Ensaios de siRNA}

Neste estudo utilizou-se a técnica de siRNA para avaliar o efeito da supressão do ERBB2 na expressão dos transcritos dos genes ATAD4, MATR3, NDRG1, ANP32B, ACTN1, CENPH, TPM1 e SPARC nas células C5.2. As células C5.2 transfectadas com siRNA controle negativo (siC) ou siERBB2 permaneceram em cultura durante 72 horas, em seguida foram utilizados para extração de RNA e proteína.

Comparada às células C5.2 mantidas em soro normal (SN), a transfecção com si controle negativo não alterou a expressão da proteína ERBB2 e do seu RNAm. As células C5.2 transfectadas com siERBB2, mostraram redução de aproximadamente $70 \%$ na expressão do RNAm e da proteína ERBB2, em relação às células $\mathrm{C5.2}$ não transfectadas ou transfectadas com siRNA controle negativo. A figura 25 ilustra o resultado do ensaio de siRNA.

Uma vez verificada que a expressão da proteína ERBB2 foi suprimida, realizou-se a análise por PCR em tempo real da expressão dos genes estudados. Como ilustrado na figura 26 , houve reduções significativas dos transcritos dos genes ATAD4 e ACTN1 após a transfecção das células com siERBB2 comparadas às células transfectadas com siC $(0,43 \pm 0,08 p=0,0002 \mathrm{e}$ $0,79 \pm 0,13 p=0,05)$.

Foram observados reduções na expressão dos transcritos dos genes NDRG1, SPARC e MATR3 nas células C5.2 após a supressão da proteína ERBB2, porém os valores não foram estatisticamente significativos (Figura 27).

As células $\mathrm{C} 5.2$ transfectadas com siERBB2 comparadas às células C5.2 transfectadas com siC mostraram aumento significativo na expressão dos transcritos do TPM1 $(1,73 \pm 0,43 \quad p=0,043)$ e um aumento, que não foi estatisticamente significativo, dos transcritos do CENPH (Figura 28).

A supressão da proteína ERBB2 não alterou a expressão dos trasncritos do $A N P 32 B$ (Figura 29). 


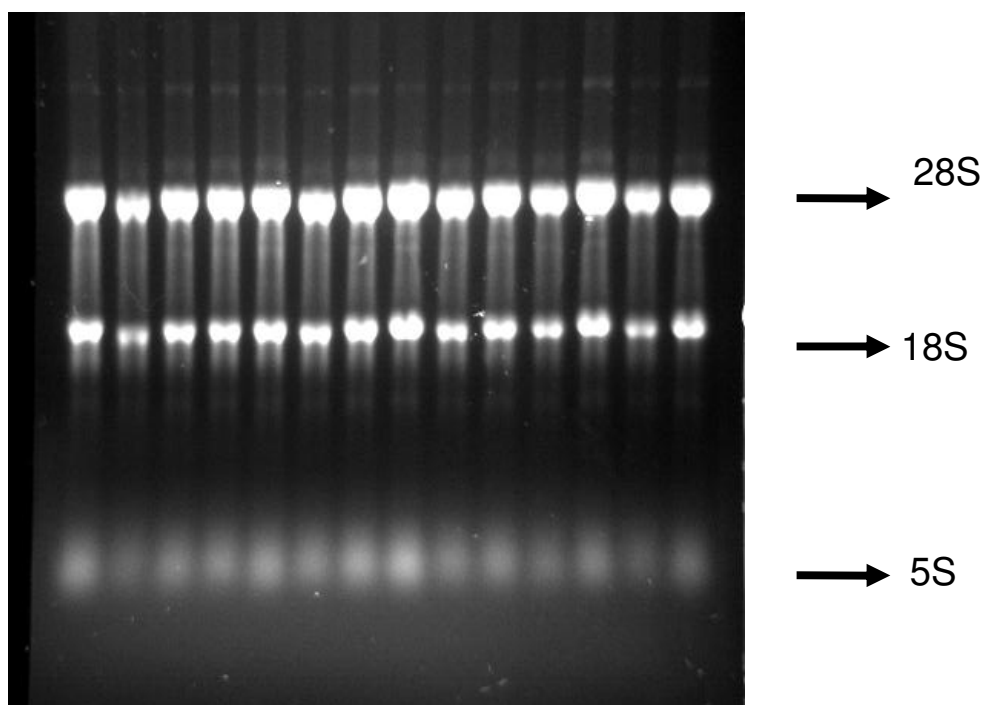

Figura 3: Gel de agarose 1\% representativo da qualidade de amostras de RNA extraídas pela técnica de guanidina fenol clorofórmio.

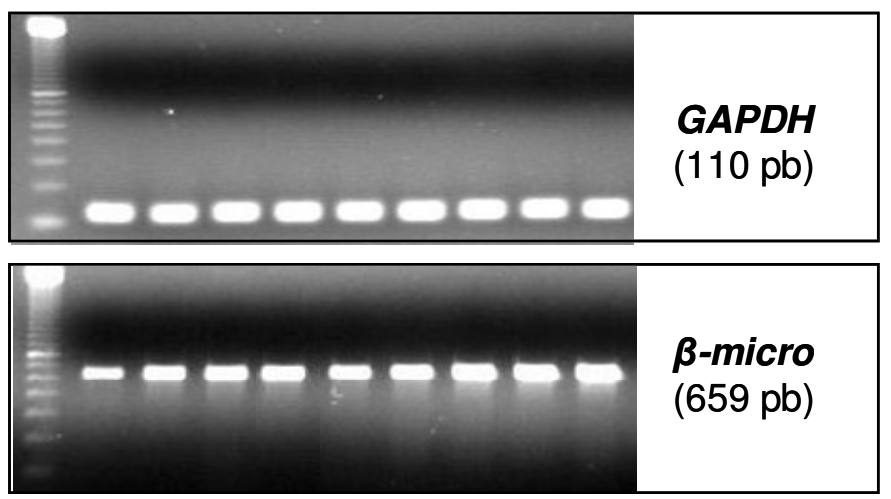

Figura 4: Amplificação dos transcritos GAPDH e $\beta$-micro em amostras das células C5.2 para verificação da qualidade e integridade do cDNA sintetizado. 

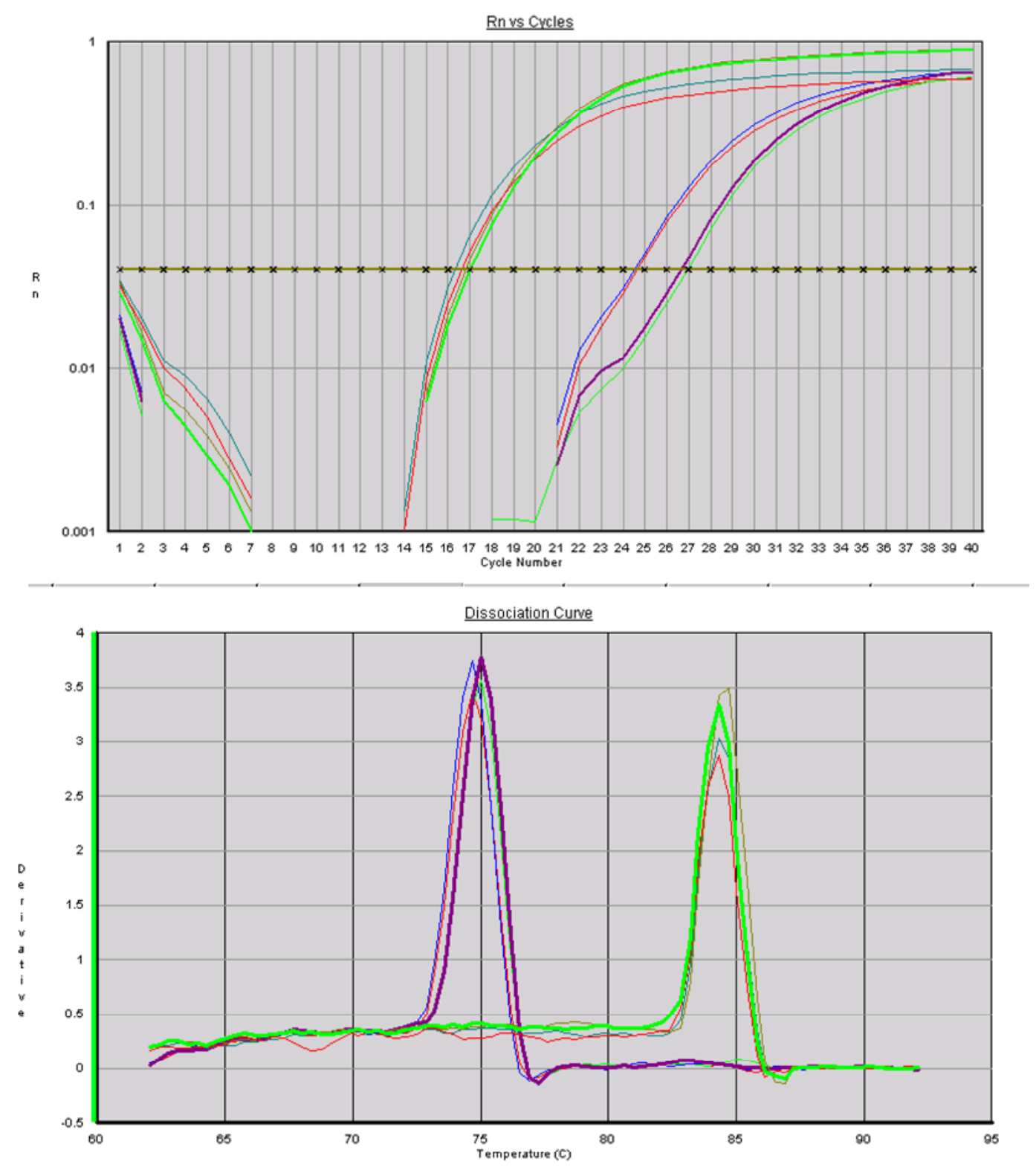

Figura 5: A- Curva de amplificação representativa das análises de expressão de PCRem Tempo Real. O primeiro grupo representa a curva de amplificação do gene de referência GAPDH nas amostras SKBr3 SN e SKBr3 tratadas com $60 \mathrm{ng} / \mathrm{ml}$ de EGF durante 6 horas; o segundo grupo representa a curva de amplificação do gene CENPH para as amostras SKBr3 SN e o terceiro grupo representa a curva de amplificação do gene CENPH para as amostras SKBr3 tratadas com $60 \mathrm{ng} / \mathrm{ml}$ de EGF durante 6 horas B- Gráfico de dissociação. As curvas de dissociação são usadas para deteç̧ão de produtos não específicos na reação. O primeiro pico representa a amplificação do gene de referência GAPDH nas amostras SKBr3 SN e SKBr3 tratadas com $60 \mathrm{ng} / \mathrm{ml}$ de EGF durante 6 horas; o segundo pico representa a amplificação do gene CENPH para as mesmas amostras. 


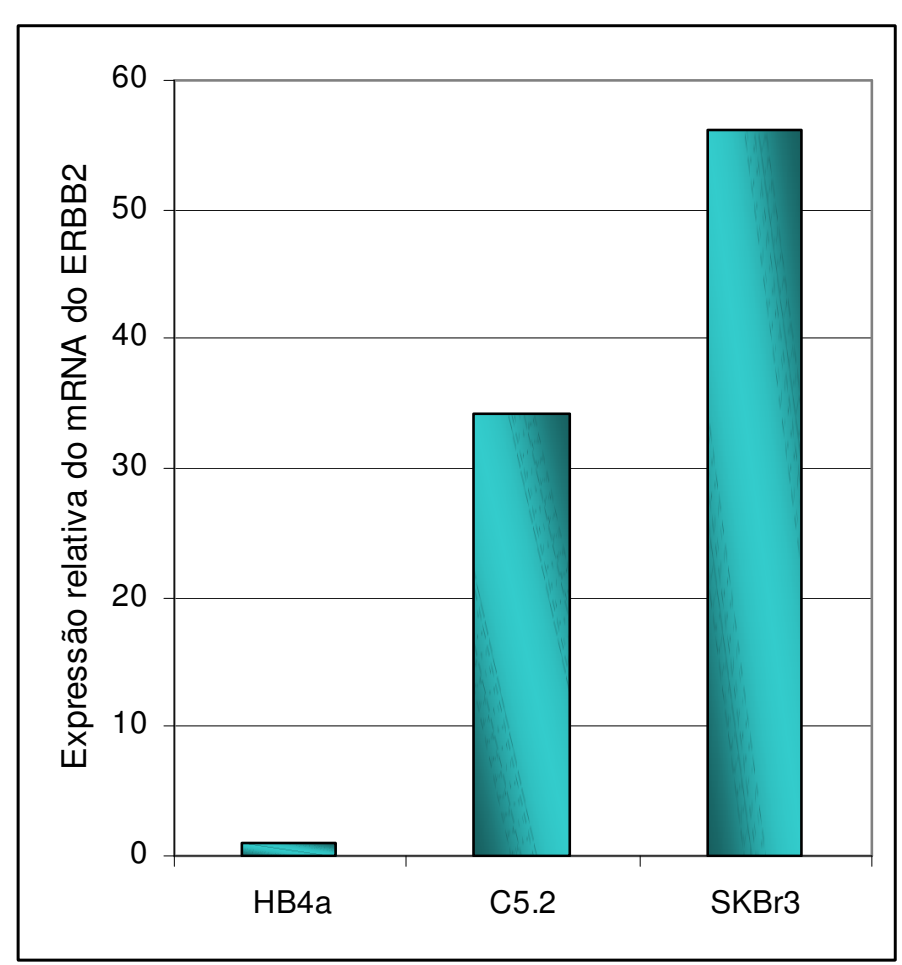

A

B

HB4a $\quad$ C5.2 SKBr3

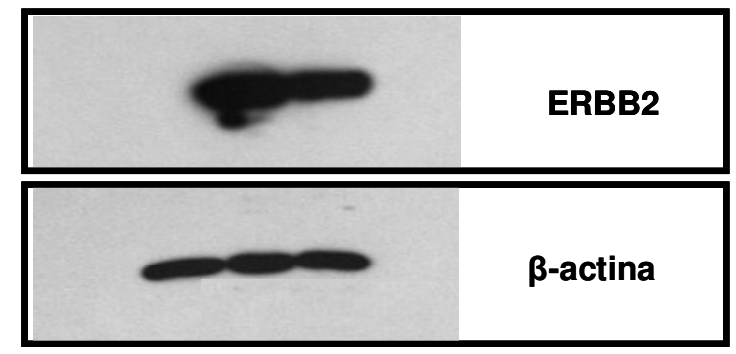

Figura 6: Análise da expressão do oncogene ERBB2 nas células HB4a, C5.2 e SKBr3. A- Expressão relativa do RNAm do gene ERBB2 nas células HB4a, C5.2 e SKBr3 mantidas em meio com 10\% de FBS. Na análise de PCR em tempo real foi utilizado como controle o GAPDH. BWestern Blot para análise da expressão da proteína ERBB2 nas células HB4a, C5.2 e SKBr3. A expressão da $\beta$-actina foi utilizada como controle de massa. 

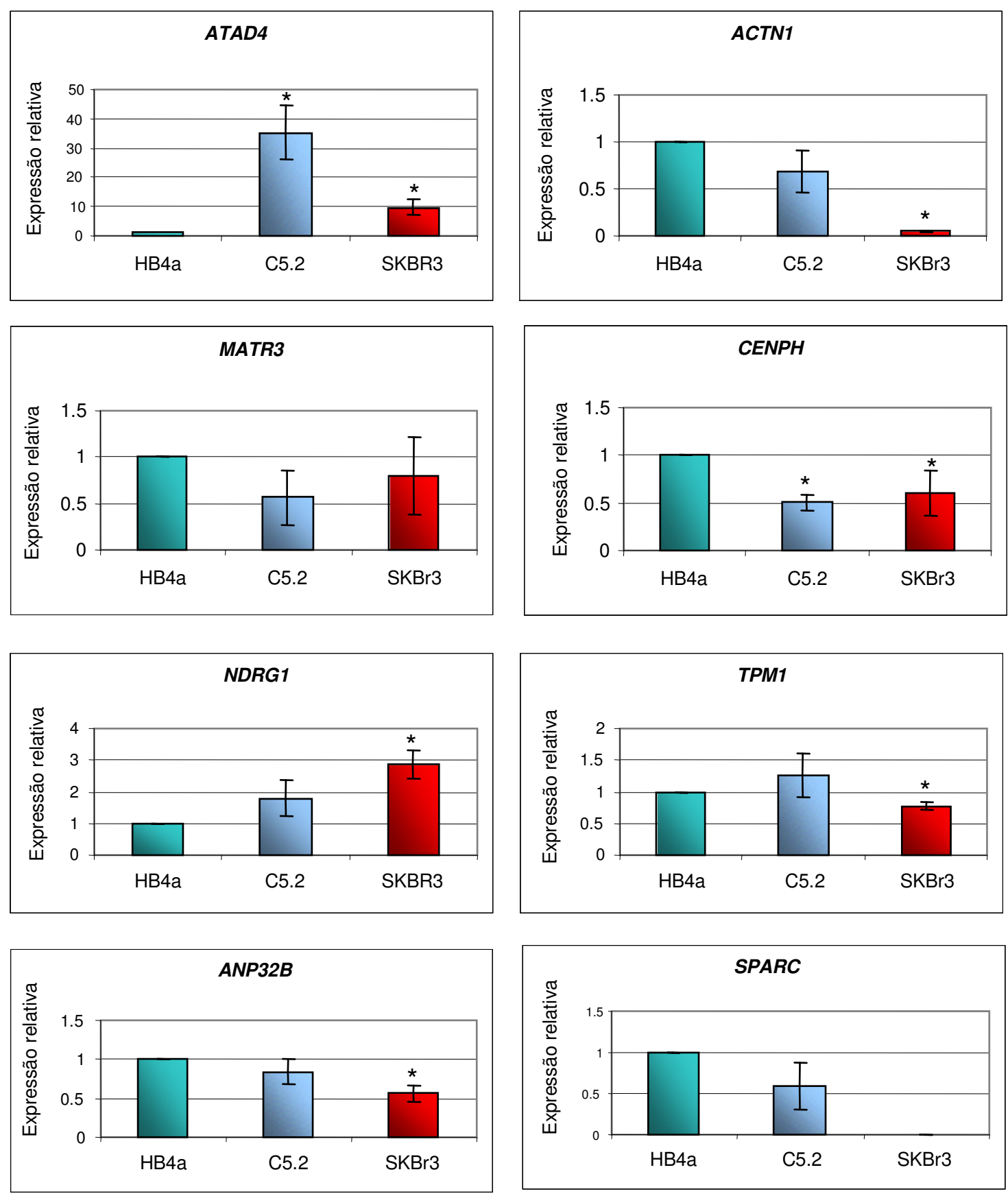

Figura 7: Expressão relativa do RNAm dos genes ATAD4, MATR3, NDRG1, ANP32B, ACTN1, CENPH, TPM1 e SPARC nas células HB4a, C5.2 e SKBr3 mantidas meio com 10\% de FBS. As barras representam a média \pm desvio padrão de 3 experimentos independentes, ${ }^{*} p<0,05$ 

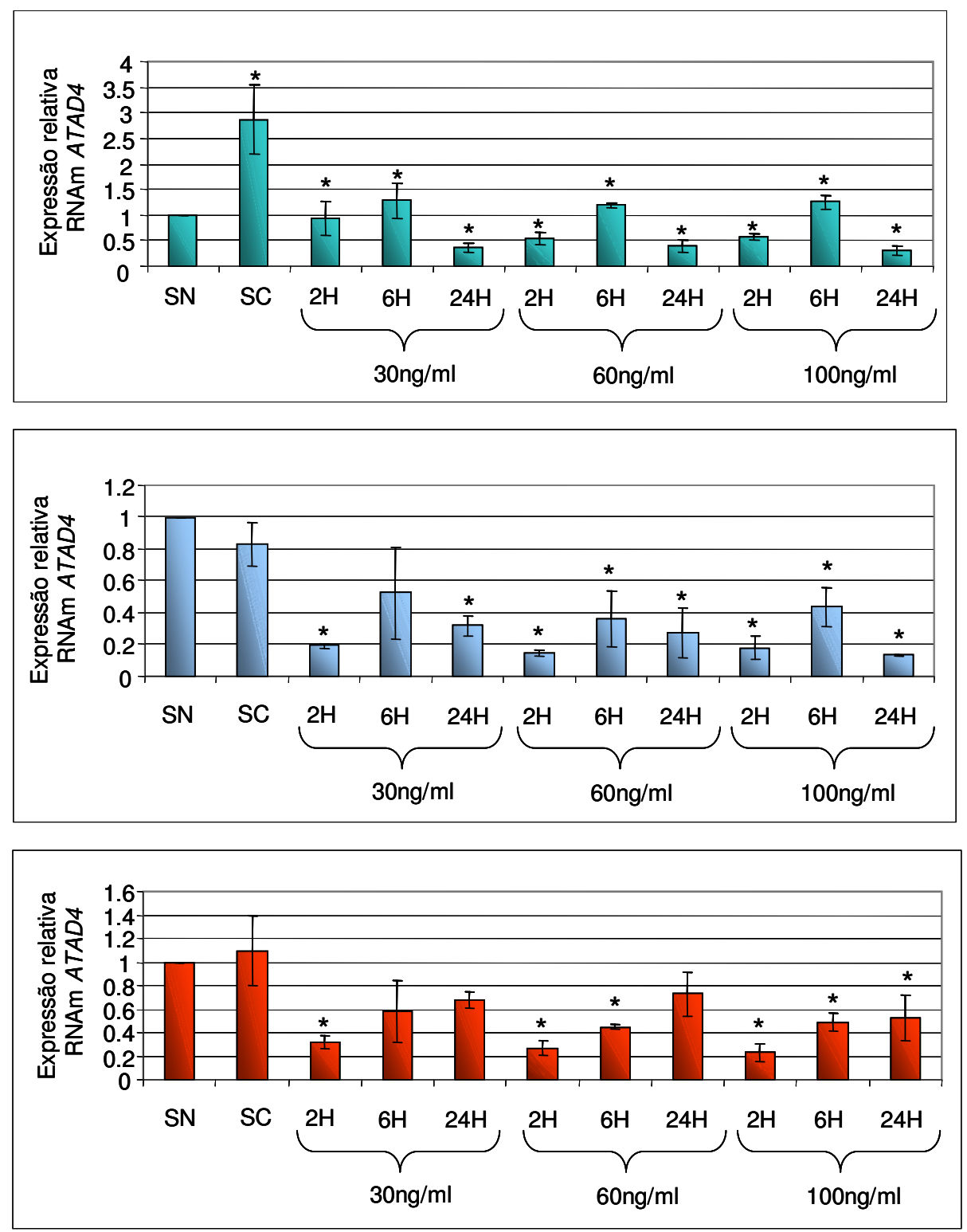

Figura 8: Expressão relativa dos transcritos do ATAD4 nas células HB4a, C5.2 e SKBr3 mantidas em SN ou SC, tratadas com 30,60 ou $100 \mathrm{ng} / \mathrm{ml}$ de EGF durante 2, 6 e 24 horas. As barras representam a média \pm desvio padrão de 3 experimentos independentes, ${ }^{*} p<0,05$ 


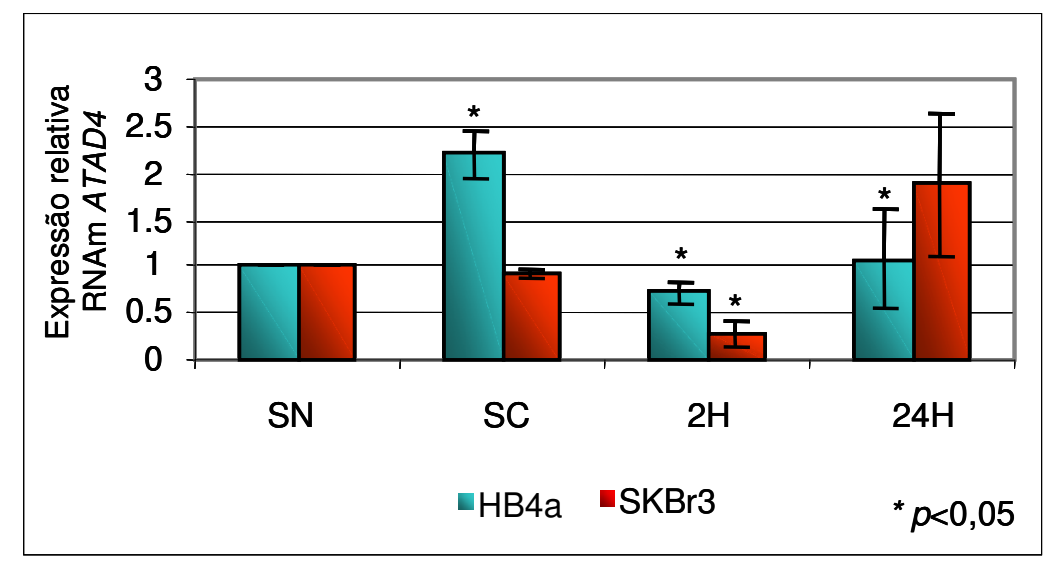

Figura 9: Expressão relativa dos transcritos do ATAD4 nas células HB4a e SKBr3 mantidas em SN ou em meio com $0,1 \%$ de FBS, tratadas com $60 \mathrm{ng} / \mathrm{ml}$ de HRG durante 2 e 24 horas. As barras representam a média \pm desvio padrão de 3 experimentos independentes, ${ }^{*} p<0,05$ 

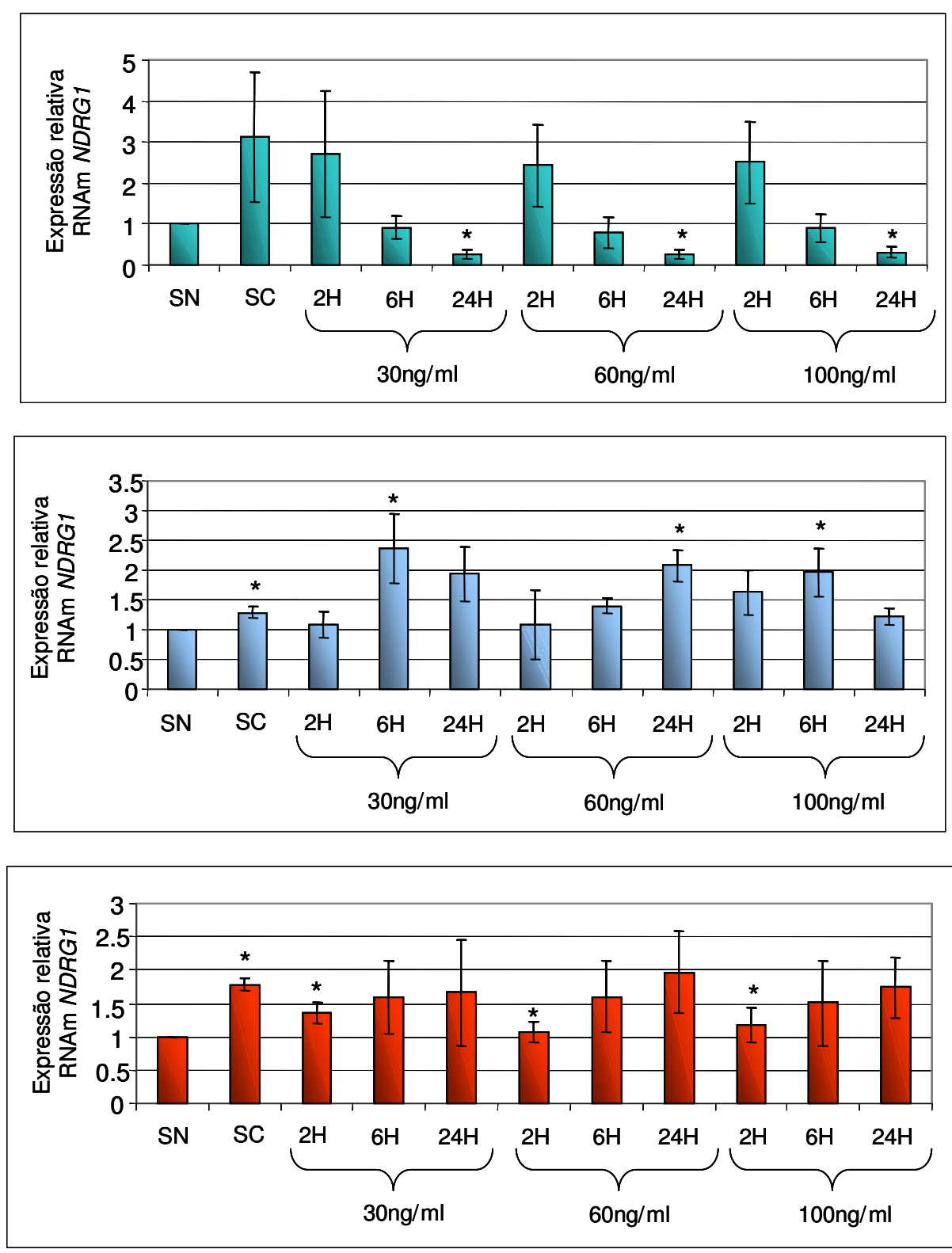

Figura 10: Perfil de expressão do gene NDRG1 após tratamento com diferentes concentrações de EGF durante 2,6 e 24 horas. As barras representam a média \pm desvio padrão de 3 experimentos independentes, ${ }^{*} p<0,05$ 


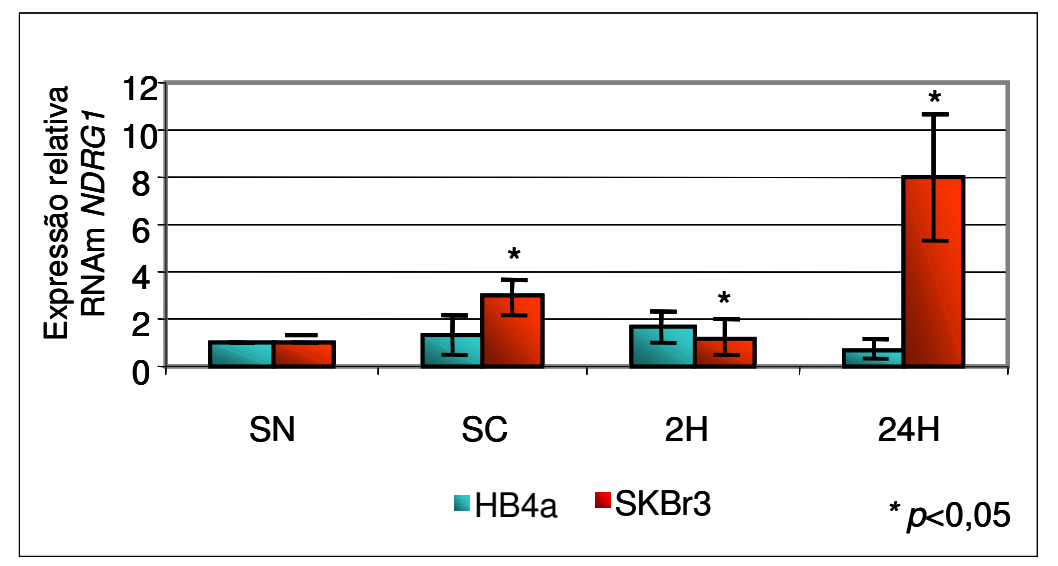

Figura 11: Expressão relativa dos transcritos do NDRG1 nas células HB4ae SKBr3 mantidas em SN ou em meio com $0,1 \%$ de FBS, tratadas com $60 \mathrm{ng} / \mathrm{ml}$ de HRG durante 2 e 24 horas. As barras representam a média \pm desvio padrão de 3 experimentos independentes, ${ }^{*} p<0,05$. 


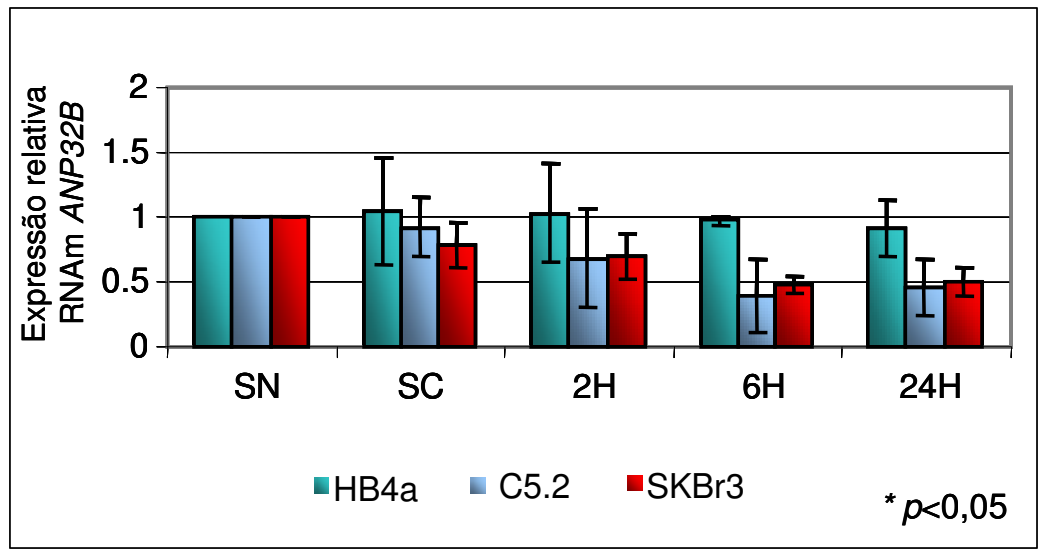

Figura 12: Perfil de expressão do gene $A N P 32 B$ após tratamento com 60ng/ml de EGF durante 2, 6 e 24 horas. As barras representam a média \pm desvio padrão de 3 experimentos independentes, ${ }^{*} p<0,05$.

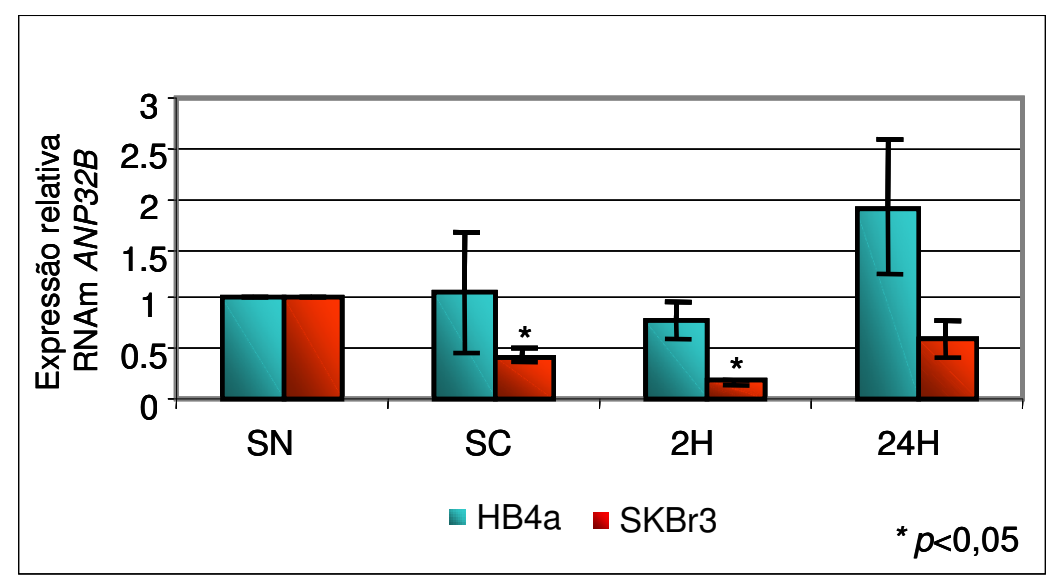

Figura 13: Expressão relativa dos transcritos do $A N P 32 B$ nas célulasHB4a e $\mathrm{SKBr} 3$ mantidas em SN ou em meio com $0,1 \%$ de FBS, tratadas com $60 \mathrm{ng} / \mathrm{ml}$ de HRG durante 2 e 24 horas. As barras representam a média \pm desvio padrão de 3 experimentos independentes, ${ }^{*} p<0,05$. 


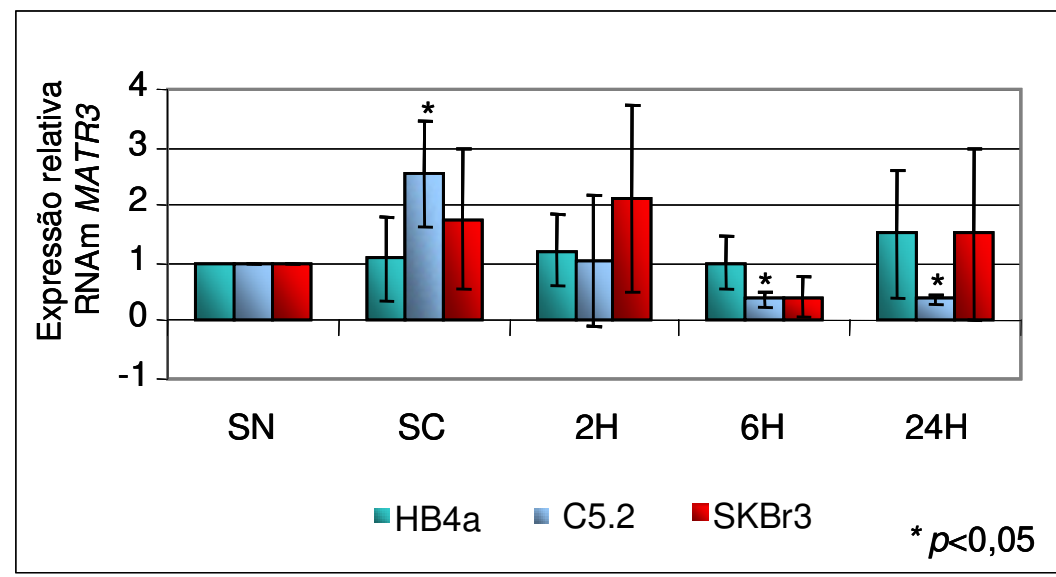

Figura 14: Expressão relativa dos transcritos do MATR3 nas células HB4a, C5.2 e SKBr3 mantidas em $\mathrm{SN}$ ou em meio com $0,1 \%$ de FBS, tratadas com $60 \mathrm{ng} / \mathrm{ml}$ de EGF durante 2,6 e 24 horas. As barras representam a média \pm desvio padrão de 3 experimentos independentes, * $p<0,05$.

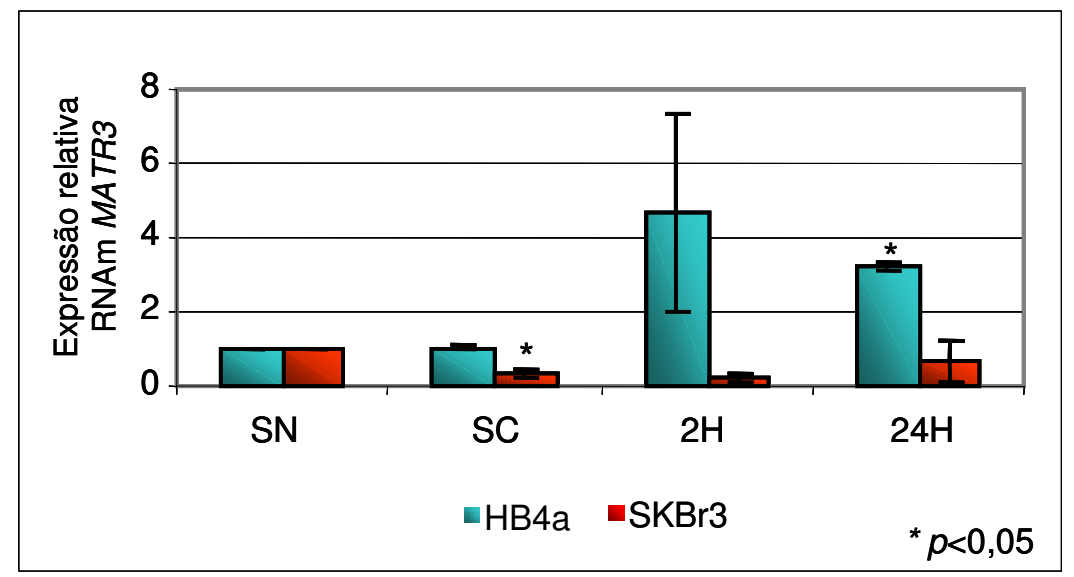

Figura 15: Perfil de expressão do gene MATR3 após tratamento com 60ng/ml de HRG durante 2 e 24 horas. As barras representam a média \pm desvio padrão de 3 experimentos independentes, ${ }^{*} \mathrm{p}<0,05$. 


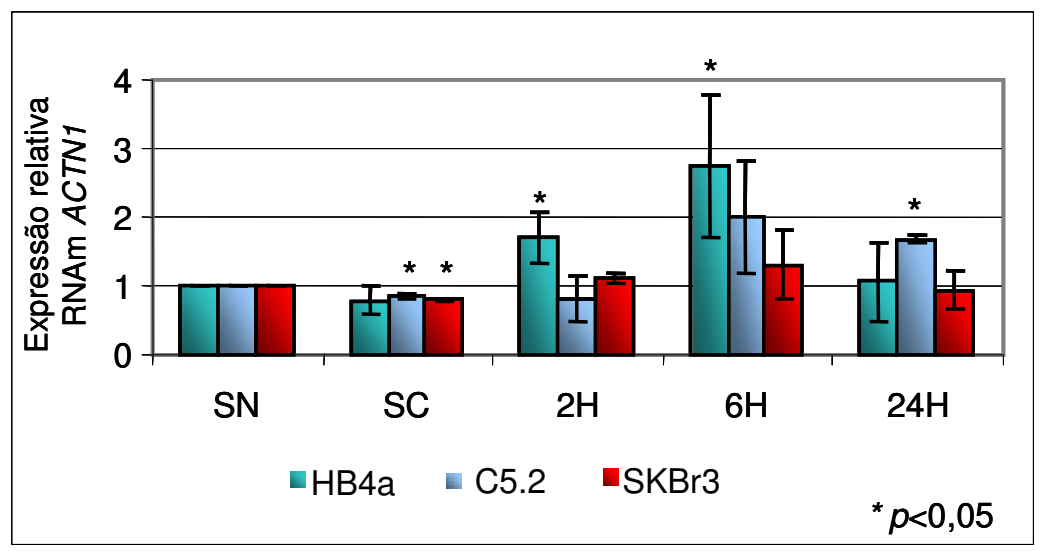

Figura 16: Expressão relativa dos transcritos do ACTN1 nas células HB4a, C5.2 e SKBr3 tratadas com $60 \mathrm{ng} / \mathrm{ml}$ de EGF durante 2, 6 e 24 horas. As barras representam a média \pm desvio padrão de 3 experimentos independentes, ${ }^{*} p<0,05$.

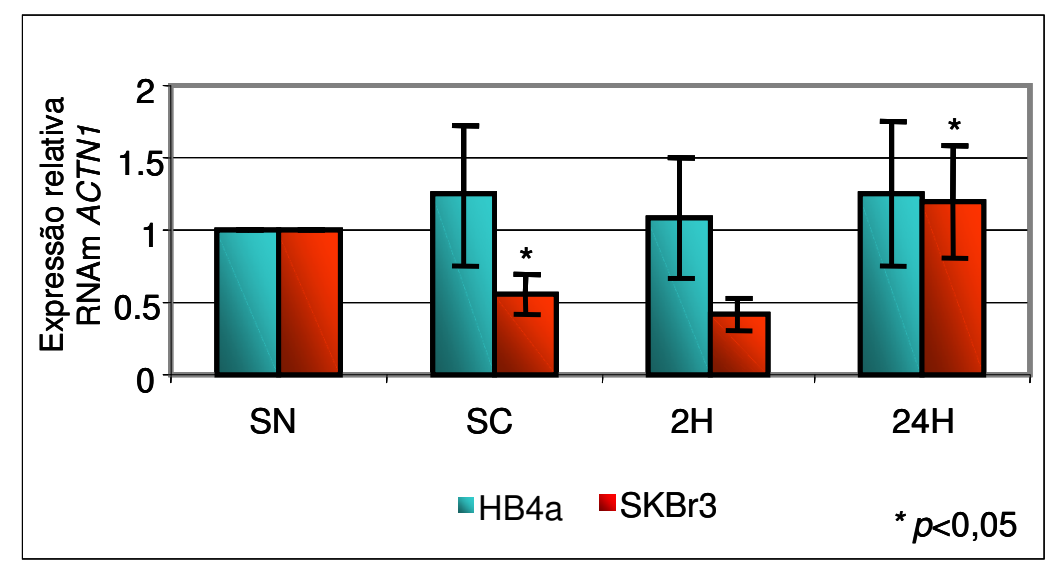

Figura 17: Perfil de expressão do gene ACTN1 após tratamento com 60ng/ml de HRG durante 2 e 24 horas. As barras representam a média \pm desvio padrão de 3 experimentos independentes, ${ }^{*} p<0,05$. 


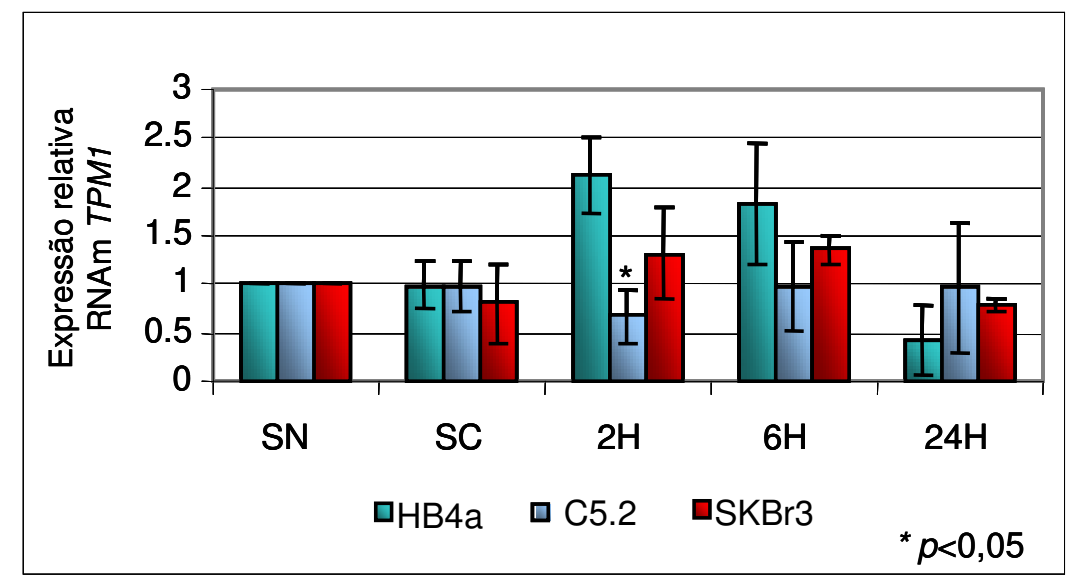

Figura 18: Expressão relativa dos transcritos do TPM1 nas células HB4a, C5.2 e SKBr3 tratadas com $60 \mathrm{ng} / \mathrm{ml}$ de EGF durante 2, 6 e 24 horas. As barras representam a média \pm desvio padrão de 3 experimentos independentes, ${ }^{*} p<0,05$.

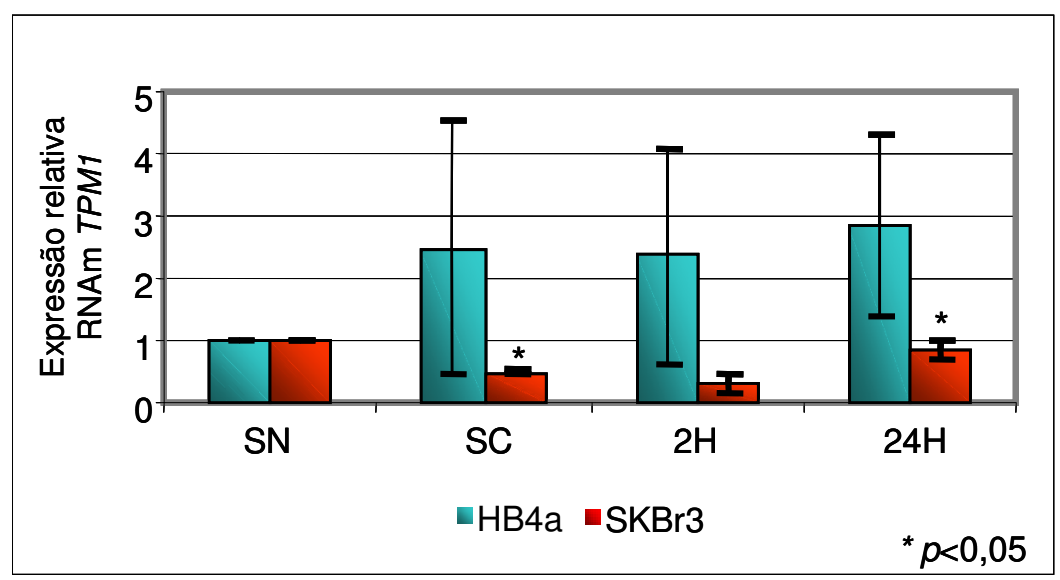

Figura 19: Expressão relativa dos transcritos do TPM1 nas células HB4a e SKBr3 mantidas em SN ou em meio com $0,1 \%$ de FBS, tratadas com $60 \mathrm{ng} / \mathrm{ml}$ de HRG durante 2 e 24 horas. As barras representam a média \pm desvio padrão de 3 experimentos independentes, * $\mathrm{p}<0,05$. 


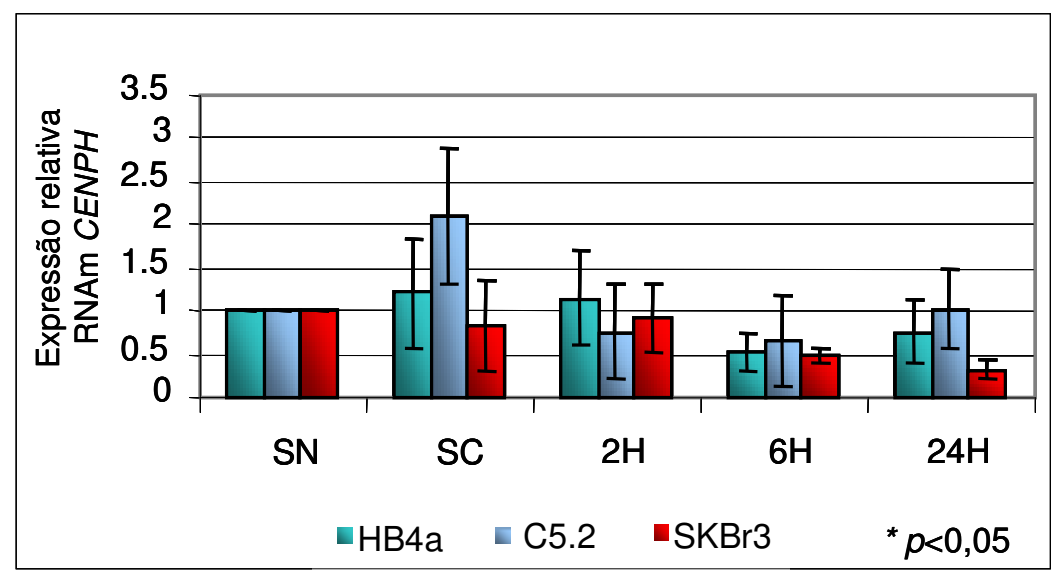

Figura 20: Expressão relativa dos transcritos do CENPH nas células HB4a, C5.2 e SKBr3 mantidas em $\mathrm{SN}$ ou em meio com $0,1 \%$ de FBS, tratadas $60 \mathrm{ng} / \mathrm{ml}$ de EGF durante 2,6 e 24 horas. As barras representam a média \pm desvio padrão de 3 experimentos independentes, ${ }^{*} p<0,05$.

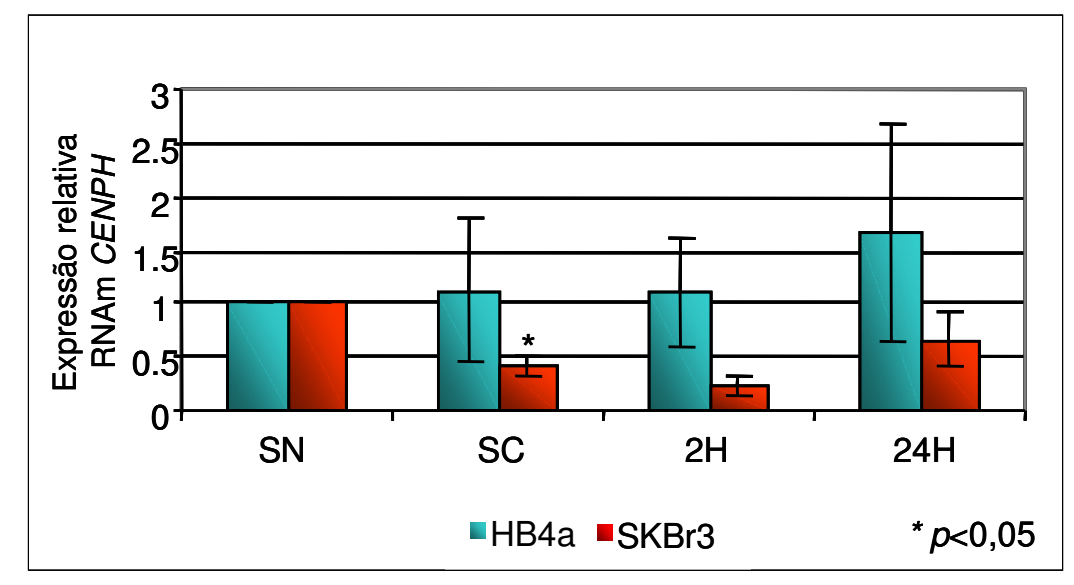

Figura 21: Expressão relativa dos transcritos do CENPH nas células HB4a e SKBr3 mantidas em SN ou em meio com $0,1 \%$ de FBS, tratadas com $60 \mathrm{ng} / \mathrm{ml}$ de HRG durante 2 e 24 horas. As barras representam a média \pm desvio padrão de 3 experimentos independentes, ${ }^{*} p<0,05$. 


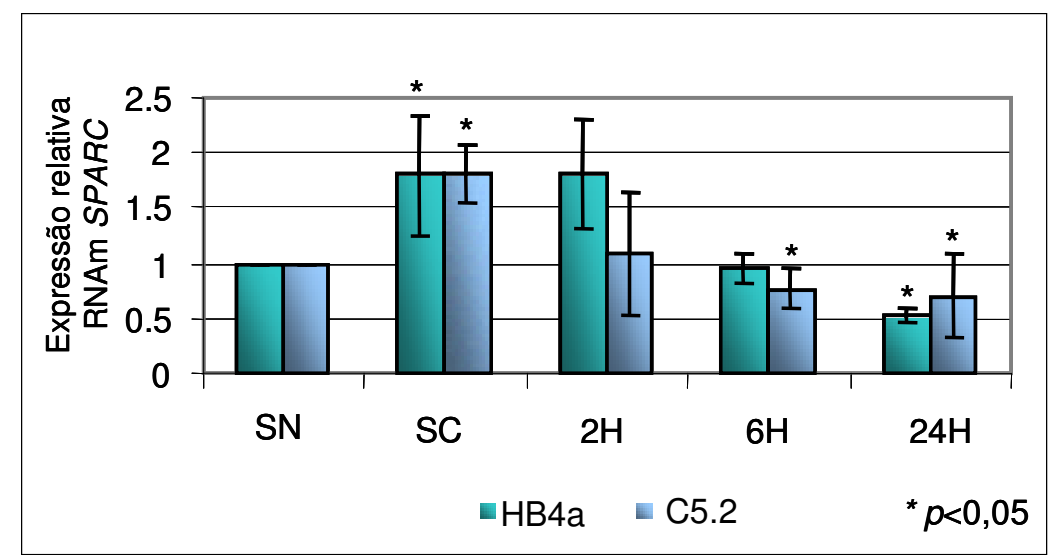

Figura 22: Perfil de expressão do gene $S P A R C$ nas células HB4a, C5.2 e SKBr3 após tratamento com $60 \mathrm{ng} / \mathrm{ml}$ de EGF durante 2, 6 e 24 horas. As barras representam a média \pm desvio padrão de 3 experimentos independentes, * $p<0,05$.

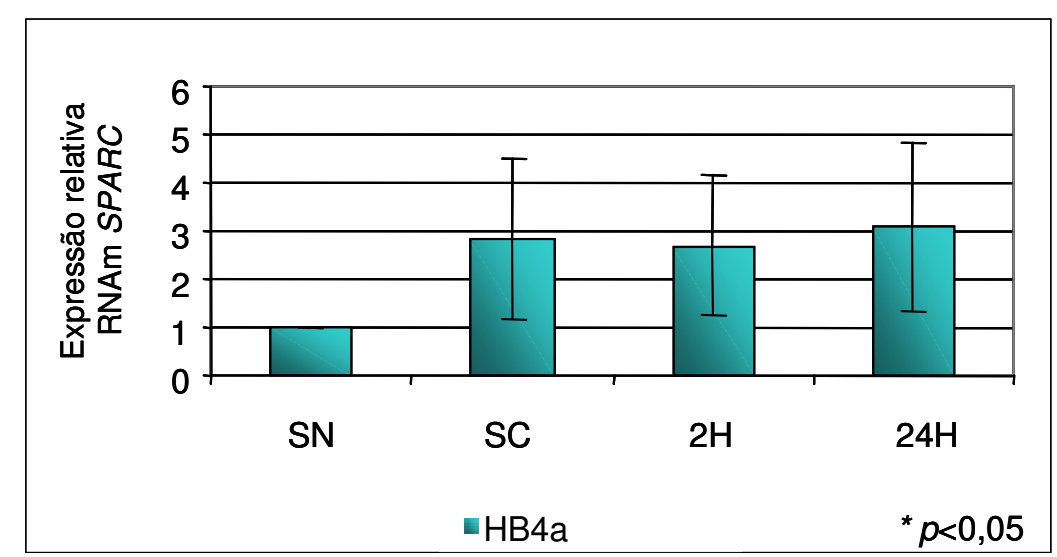

Figura 23: Expressão relativa dos transcritos do $S P A R C$ nas células HB4a e SKBr3 mantidas em SN ou em meio com $0,1 \%$ de FBS, tratadas com $60 \mathrm{ng} / \mathrm{ml}$ de HRG durante 2 e 24 horas. As barras representam a média \pm desvio padrão de 3 experimentos independentes, * $p<0,05$. 


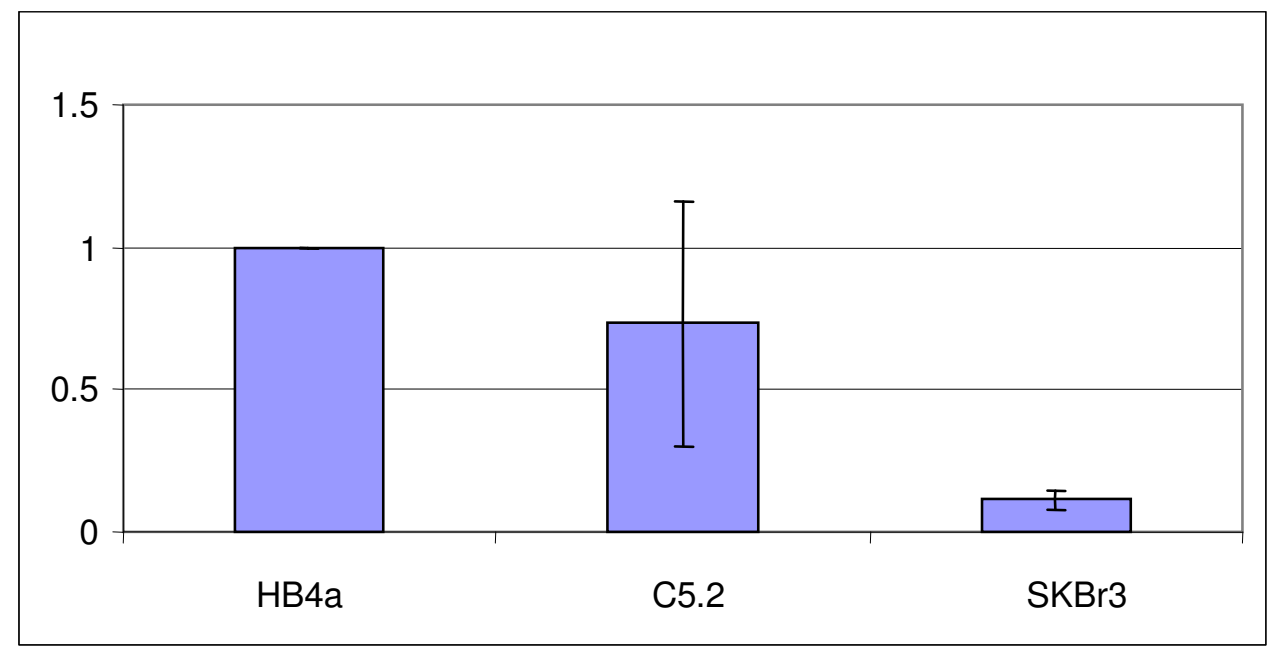

Figura 24: Perfil de expressão do gene EGFR nas células HB4a, C5.2 e SKBr3. As barras representam a média \pm desvio padrão de 3 experimentos independentes. 
A

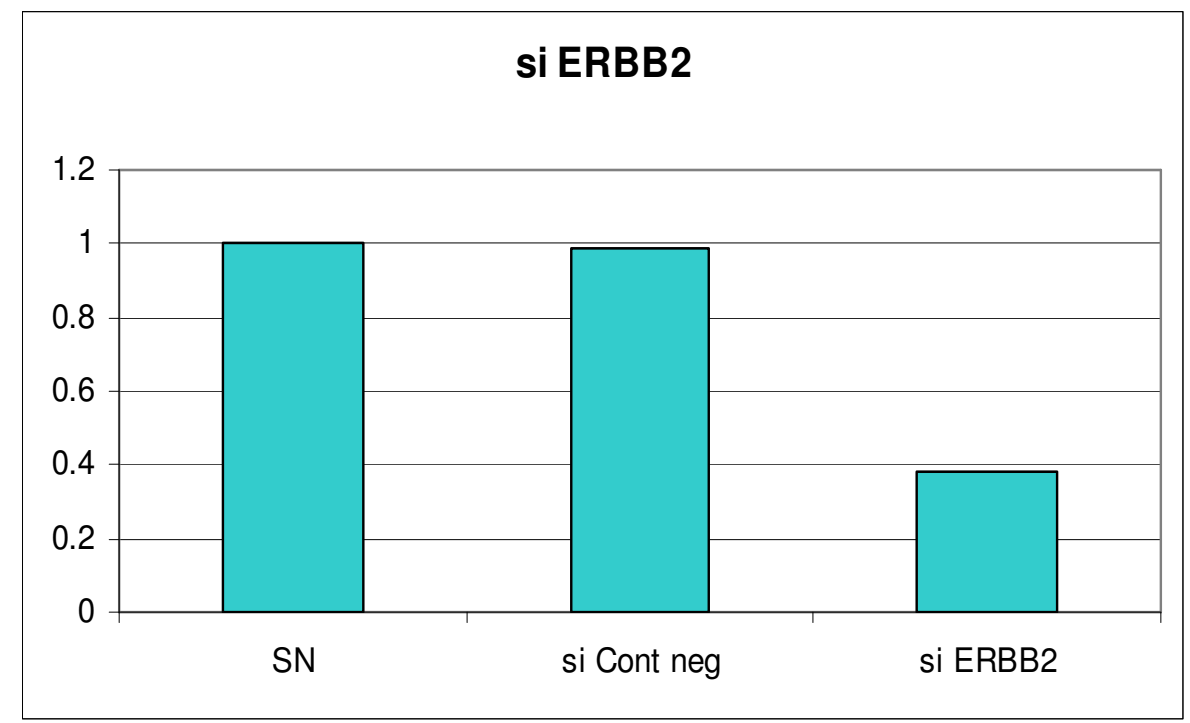

SN $\quad$ SiC SiERBB2

B

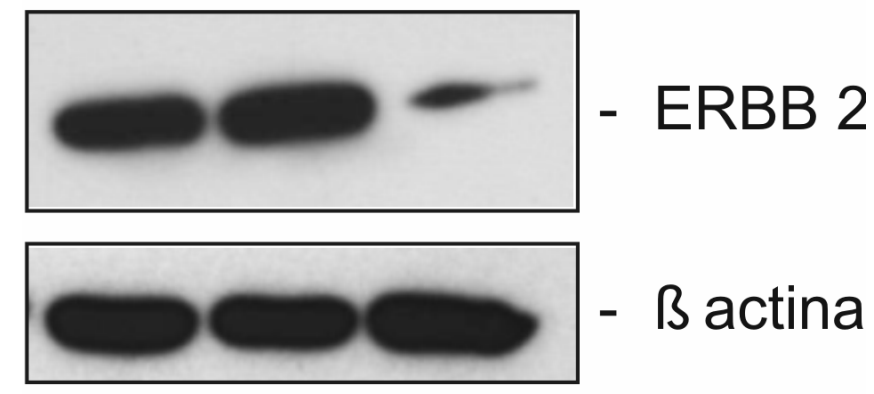

Figura 25: Análise da expressão do oncogene ERBB2 nas células C5.2 após o ensaio de siRNA. A- Expressão relativa do mRNA do gene ERBB2 nas células C5.2 mantidas em soro normal, transfectadas com si controle negativo ( $\mathrm{siC}$ ), e transfectadas com siERBB2. Na análise de PCR em tempo real foi utilizado como controle o gene GAPDH. BWestern Blot para análise da proteína ERBB2. A expressão da $\beta$ actina foi utilizada como controle de massa. 

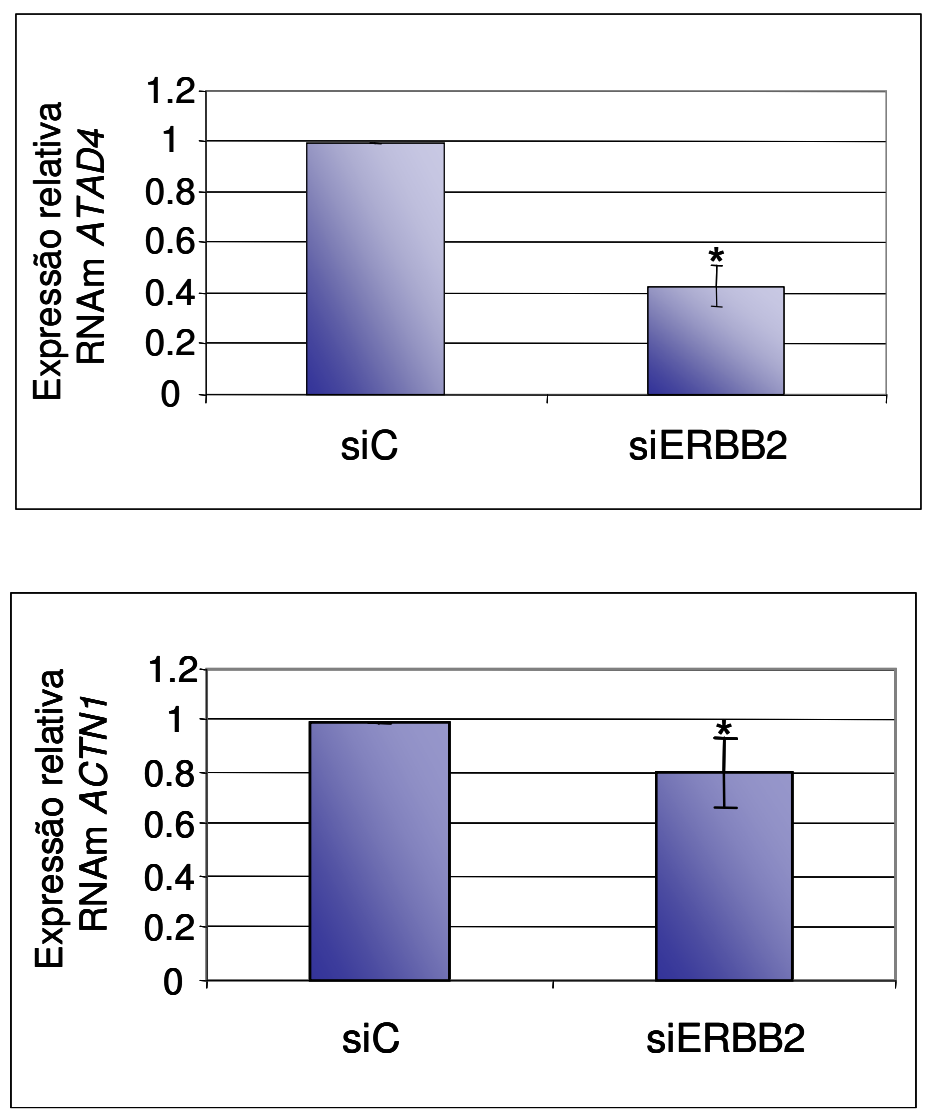

Figura 26: Expressão relativa dos transcritos do genes ATAD4 e ACTN1 nas células C5.2 transfectadas com si controle negativo e siERBB2. As barras representam a média \pm desvio padrão de 3 experimentos independentes, ${ }^{*} p<0,05$. 

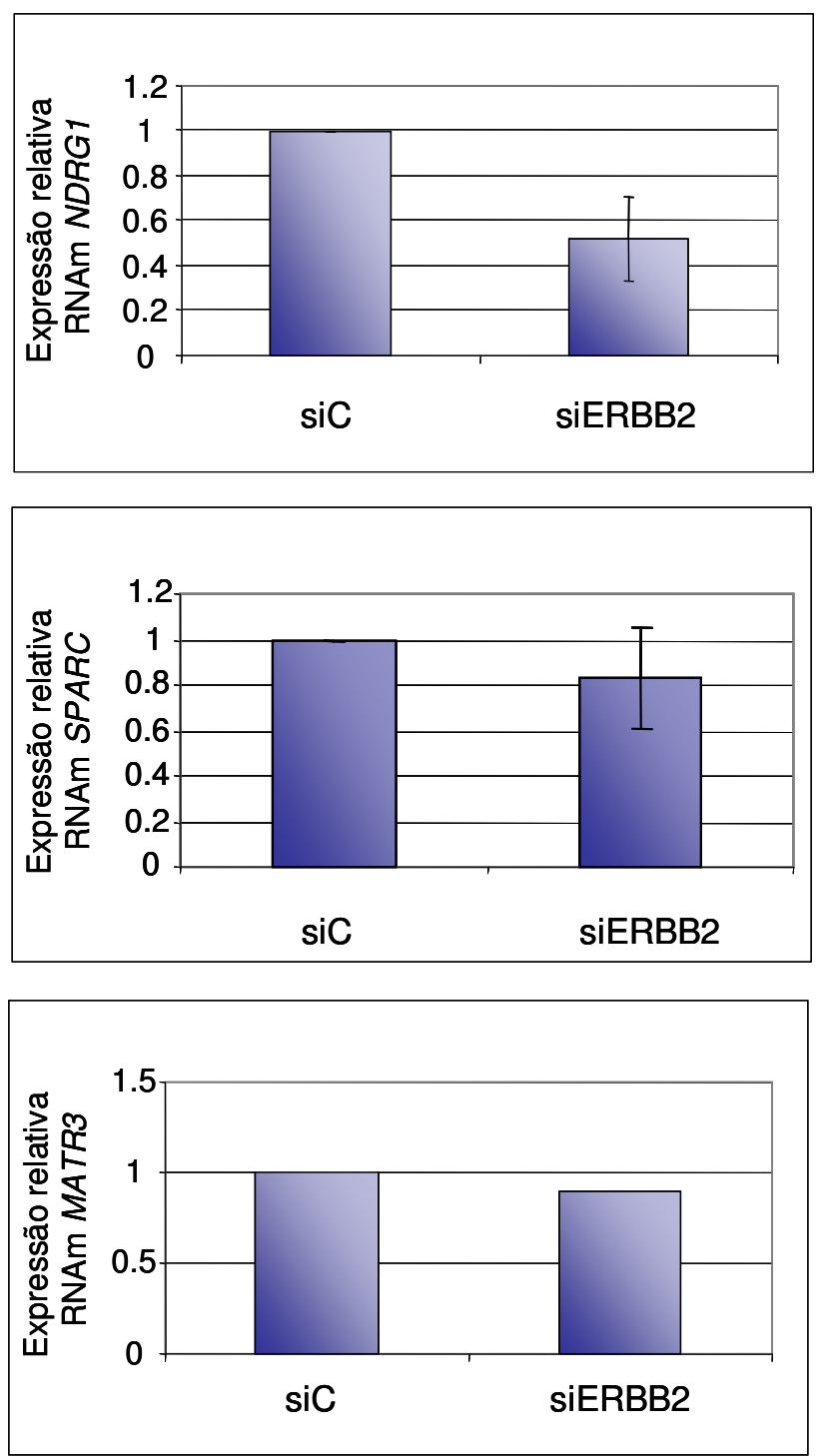

Figura 27: Expressão relativa dos transcritos dos genes NDRG1, SPARC e MATR3 nas células C5.2 transfectadas com si controle negativo e siERBB2. As barras representam a média \pm desvio padrão de 3 experimentos independentes. 

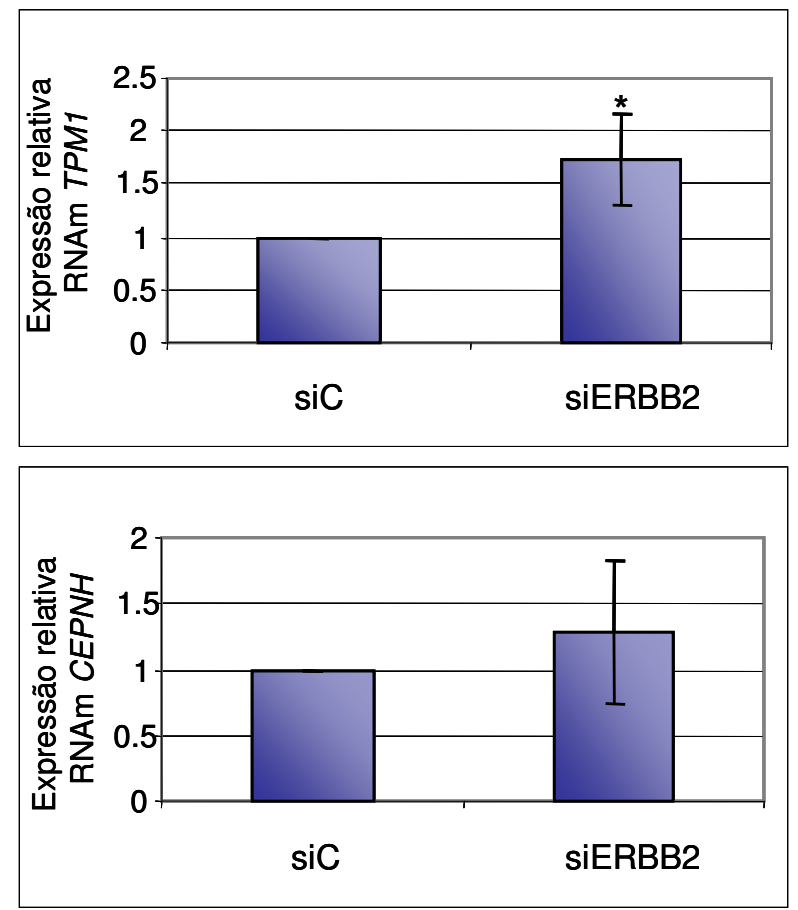

Figura 28: Expressão relativa dos genes TMP1 e CENPH nas células C5.2 transfectadas com si controle negativo e siERBB2. As barras representam a média \pm desvio padrão de 3 experimentos independentes, ${ }^{*} p<0,05$.

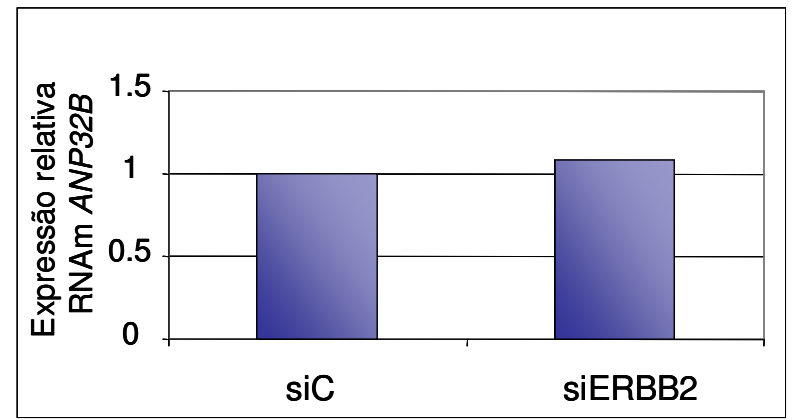

Figura 29: Expressão relativa dos transcritos do $A N P 32 B$ nas células $C 5.2$ transfectadas com si controle negativo e siERBB2. As barras representam a média \pm desvio padrão de 3 experimentos independentes. 
DISCUSSÃO 


\section{DISCUSSÃO}

Aproximadamente $30 \%$ dos tumores de mama apresentam expressão aumentada do oncogene ERBB2 (SLAMON et al., 1987; NAGAl et al., 1993) o que também está relacionado com a ausência de receptor de estrógeno e menor intervalo livre de doença e sobrevida total das pacientes com câncer de mama (NAGAl et al., 1993; DOWSETT et al., 2001). O aumento da expressão de ERBB2 ativa importantes vias de transdução de sinais, incluindo ras/MAPK e PI3K/AKT, que regulam genes envolvidos em processos como proliferação, crescimento e morte celular, e contribuem para a tranformação maligna da mama (HUNG e LAU 1999; YARDEN e SLIWKOWSKI 2001; NICHOLSON e ANDERSON, 2002; MCCUBREY et al., 2007).

A análise de genes que são diferencialmente expressos em cânceres de mama que apresentam expressão aumentada de ERBB2 pode contribuir para compreensão dos processos de tumorigênese e quimioresistência, além de auxiliar no diagnóstico e tratamento do câncer de mama.

Os genes SPARC, MCG11242, ACTN1, TPM1, NDRG1, MATR3, $A N P 32 B$ e $C E N P H$ foram identificados previamente em nosso grupo como diferencialmente expressos nas células que apresentam expressão aumentada de ERBB2 (DOS SANTOS et al., 2006). Neste estudo analisamos o perfil de expressão destes transcritos em linhagens de células de mama com diferentes níveis do receptor ERBB2 após os tratamentos com EGF e HRG e após a supressão do receptor pela técnica de siRNA.

Em mama não há definição de um ligante específico para o receptor ERBB2. Este receptor é ativado pela formação de dímeros com os outros membros da família de receptores de fatores de crescimento epitelial. O EGF ligante específico do receptor EGFR foi inicialmente escolhido para este estudo. Porem, observou-se que as células HB4a respondiam melhor ao tratamento com EGF que as células $\mathrm{C} 5.2$ e $\mathrm{SKBr}$. Devido às diferenças nas respostas das células avaliou-se o perfil de expressão dos transcritos do EGFR nas três linhagens. Observou-se, então, que as células C5.2 e SKBr3 apresentavam níveis de expressão de EGFR inferiores aos níveis das células 
HB4a. Sendo assim, optamos por avalia também o efeito da heregulina nas células HB4a e SKBr3.

Harris et al. (1999) demonstraram que o EGF aumenta a fosforilação da tirosina dos receptores ERBB2 e EGFR nas células HB4a e C5.2. Enquanto o tratamento com HRG aumenta a fosforilação da tirosina dos receptores ERBB2 apenas nas células que possuem expressão aumentada do receptor. Os tratamentos com EGF e HRG também aumenta a fosforilação da tirosina da proteína adaptadora Shc nas células HB4a e em maior proporção nas células C5.2 (HARRIS et al., 1999).

\subsection{SPARC}

O gene SPARC, também conhecido como osteonectina e BM40, codifica para uma glicoproteina secretada que possui afinidade de ligação ao cálcio, interage com receptores da superfície celular, matriz extracelular e fatores de crescimento (FRAMSON e SAGE, 2004). Bradshaw e Sage (2001) atribuem a de-adesão, anti-proliferação e regulação da produção da matriz extracelular como as três principais funções do SPARC.

Os dados da literatura que relacionam câncer de mama e expressão de SPARC são controversos. Estudo in vitro com clones da célula de câncer MDAMB-231 transfectados com SPARC mostraram inibição da proliferação celular (DHANESUAN et al., 2002). Outro estudo mostrou que a alta expressão de SPARC em células de carcinoma de mama inibe a formação de metástase (KOBLINSKI et al., 2005). Além disso, tumores transfectados com SPARC apresentaram aumento de apoptose e inibição do crescimento tumoral (CHLENSKI et al., 2006). A redução da expressão do SPARC é um indicativo de metástase em pacientes com câncer de mama, porém um estudo utilizando camundongos com câncer de mama espontâneo não apresentou diferença significativa na iniciação e progressão do tumor entre os camundongos $S P A R C^{+/}$e $S P A R C^{\%}$, indicando que apenas a perda desta proteína é insuficiente para promover ou inibir a progressão do câncer de mama (WONG et al., 2008). 
Por outro lado, células tumorais apresentaram altos níveis de RNAm e proteína SPARC comparadas ao tecido mamário normal (WATKINS et al., 2005). Foi observado ainda, maior expressão de $S P A R C$ em tumores nódulo positivos em relação aos tumores nódulo negativo (WATKINS et al., 2005). 0 remodelamento do estroma associado com câncer de mama invasivo foi relacionado ao aumento da expressão de SPARC (BARTH et al., 2005).

Nossos resultados mostram que a expressão aumentada de ERBB2 reprime a expressão dos transcritos do SPARC, corroborando com os resultados observados em outros estudos que utilizaram as técnicas de SAGE, e microaray (DOS SANTOS et al., 2006; WHITE et al., 2004; MACKAY et al., 2003). Adicionalmente, linhagens de fibroblastos de camundongos $\mathrm{NIH}-3 \mathrm{T3}$ mostraram redução na expressão do gene SPARC após transfecção com ERBB2 (BECKERS et al., 2005).

Observou-se uma pequena redução na expressão do SPARC após a supressão do ERBB2 pela técnica de siRNA. Isso sugere que a diferença na expressão do SPARC encontrada entre as células HB4a e C5.2 não é apenas dependente diretamente dos níveis de ERBB2 ou da sua ativação constitutiva, mas pode ser conseqüência da ativação dependente de ligantes.

A redução na expressão dos transcritos SPARC após os tratamentos com EGF deve ser dependente de vias de sinalização ativadas pelo receptor ERBB2. Isso porque as células que apresentam expressão aumentada de ERBB2 mostram redução do SPARC já após 2 horas de tratamento enquanto as células HB4a a redução ocorre apenas após 6 e 24 horas. $O$ tratamento com HRG não alterou a expressão dos transcritos do SPARC nas células HB4a. Esse resultado reforça a idéia que o receptor ERBB2 é responsável por reprimir este gene, pois foi verificada que a exposição à HRG não causa fosforilação dos receptores ERBB2 nas células com níveis normais deste receptor (HARRIS et al., 1999).

A expressão aumentada de ERBB2 é freqüentemente associada à resistência aos quimioterápicos (CHEN et al., 2003). Adicionalmente, os baixos níveis da proteína SPARC foram associados à resistência a quimioterápicos em câncer coloretal (TAl et al., 2005). Esses dados indicam que a resistência a quimioterápicos observadas nas células com expressão aumentada de ERBB2 pode estar associada à redução da expressão do SPARC. 


\subsection{NDRG1}

Neste estudo foi observado maior expressão do gene NDRG1 nas células C5.2 que possuem expressão aumentada de ERBB2, confirmando estudos anteriores (DOS SANTOS et al., 2006; MACKAY et al., 2003). O aumento da expressão desse gene também foi observado na linhagem celular de adenocarcinoma de mama SKBr3. Após a transfecção das células $\mathrm{C} 5.2 \mathrm{com}$ siERBB2 houve redução de 2 vexes na expressão dos transcritos NDRG1, sugerindo que a expressão aumentada desse gene observada nas células C5.2 pode ser devido a sinalização constitutiva decorrente dos maiores níveis de ERBB2 nestas células.

A expressão aumentada de NDRG1 é observada em cânceres de pele, pulmão, fígado, próstata, mama e cérebro (CANGUL, et al., 2002). A expressão aumentada de NDRG1 observada nos tumores pode ser devido às condições de hipoxia das células tumorais uma vez que o gene NDRG1 é induzido por condições de hipoxia através da via de sinalização HIF-1 (SALNIKOW et al., 2000, SIBOLD et al., 2007). Durante a hipoxia ocorre aumento do $\mathrm{Ca}^{+2}$ intracelular o que também induz a expressão de NDRG1 (SALNIKOW et al., 2002).

Neste estudo observou-se que a expressão do NDRG1 nas células HB4a foi regulada pela exposição ao EGF e à HRG de maneira semelhante. As células $\mathrm{SKBr} 3$ também mostraram perfis de expressão semelhantes após os tratamentos com EGF e com HRG, ocorrendo uma pequena redução após 2 horas de tratamento. As células $\mathrm{SKBr} 3$ possuem um perfil diferente do observado nas células HB4a. A modulação do NDRG1 já após 2 horas de tratamento nas células SKBr3 pode ser devido a maior expressão de ERBB2 nestas células. Enquanto a maior redução observada nas células HB4a pode ser devido a maior formação de dímeros ERBB1-ERBB2.

\subsection{ACTN1}

O gene ACTN1 localizado no cromossomo 14q22-q24 codifica para a proteína actinina 1 , a qual é composta de dois monômeros antiparalelos de 
$100 \mathrm{kDa}$ que se liga aos filamentos de actina de maneira paralela (CABELLO et al., 2007). Esta molécula apresenta localizações subcelulares, incluindo sítios de contato célula-célula, célula-matriz e protusão celular, sendo importante para a manutenção da estabilidade do citoesqueleto de actina (OTEY e CARPEN, 2004).

Estudo com células NIH3T3 e MDCK (Madin-Darby Canine Kidney) mostrou a interação da actinina 1 com a MEKK1 (ativador da via SAPK), assim a MEKK1 modula a função da actinina 1 e consequentemente regula 0 citoesqueleto de actina (CHRISTERSON et al., 1999). Christerson et al. (1999) sugeriram que a associação de MEKK1 com actinina 1 é importante para a especificidade e função da sinalização dependente de MEKK1. Devido ao envolvimento da actinina 1 na via de sinalização MEKK/calpaina acredita-se que essa proteína contribui para o desarranjo da adesão focal necessário para a migração celular (OTEY e CARPEN, 2004).

Neste estudo os transcritos do ACTN1 foram encontrados menos expressos nas células $\mathrm{C} 5.2$ e $\mathrm{SKBr} 3$, confirmando dados anteriores do nosso grupo (DOS SANTOS et al., 2006).

Harris et al. (1999) sugeriram que as alterações morfológicas observadas nas células $\mathrm{C} 5.2$ em relação as células HB4a estão relacionadas com o aumento de ERBB2. A redução da expressão dos transcritos do ACTN1 pode contribuir para as alterações morfológicas das células C5.2, que são mais finas e alongadas e não possuem inibição de crescimento por contato.

As células C5.2 transfectadas com siERBB2 apresentaram uma tendência a diminuição da expressão do ACTN1. Esse resultado indica que a diminuição dos transcritos $A C T N 1$ observada entre as células C5.2 em relação às células HB4a, não é decorrente somente do excesso de receptores ERBB2.

Nas células HB4a o tratamento com EGF aumenta a expressão dos transcritos do ACTN1, diferente das células SKBr3. Nestas células com expressão aumentada de ERBB2 o tratamento não altera a expressão deste gene. O mesmo não foi observado nas células C5.2. Esses resultados indicam que o aumento do gene ACTN1 observado nas células HB4a são devido à sinalização ERBB1.

O tratamento com HRG não alterou a expressão do ACTN1 nas células HB4a. Por outro lado, nas células SKBr3, que apresentam expressão 
aumentada de ERBB2, os transcritos ACTN1 foram induzidos pelo tratamento com $H R G$, indicando que a $H R G$ regula a expressão destes transcritos via ERBB2.

\subsection{TPM1}

A tropomiosina 1 (TPM1) pertence a uma família de proteínas que se ligam a actina e estabilizam os microfilamentos (PAWLAK e HELFMAN, 2001). Uma das principais características das células malignas é a presença do citoesqueleto de actina alterado, resultante da supressão de várias proteínas de ligação a actina como as tropomiosinas (Revisado em NEILL et al., 2008). Alterações no citoesqueleto também estão associadas à metástase tumoral (BISSEL et al., 1999).

Neste estudo os transcritos do TPM1 foram encontrados menos expressos nas células $\mathrm{SKBr} 3$ em relação às células $\mathrm{HB} 4 \mathrm{a}$, enquanto nas células C5.2 houve um pequeno aumento dos transcritos do TPM1. Diferente das células HB4a as células C5.2 não possuem inibição de crescimento por contato, são células mais finas e alongadas que as células HB4a (HARRIS et al., 1999). Essas alterações morfológicas observadas nas células C5.2 estão associadas aos maiores níveis de ERBB2 (HARRIS et al., 1999).

Foi observado que a reorganização do citoesqueleto resultante da expressão de TPM1 provoca anoikis em células de câncer de mama (RAVAL et al., 2003; BHARADWAJ, et al, 2005). Mahadev et al., (2002) observaram que a expressão de TPM1 induz significativa diminuição do crescimento de células de carcinoma de mama (MCF-7) e impede o crescimento independente de ancoragem das células de câncer de mama MCF-7 e MDA-MB-231.

Após a supressão do ERBB2 pelo siRNA houve aumento na expressão destes transcritos, sugerindo que a menor expressão dos transcritos do TMP1 observada nas células C5.2 e SKBr3 é decorrente da presença de ERBB2, independente de ligante.

Nas células HB4a e $\mathrm{SKBr} 3$ a tendência de aumento dos transcritos TMP1 após os tratamentos com EGF, pode ser dependente da sinalização pelo heterodímero ERRB1-ERBB2, uma vez que os maiores aumentos são 
observados nas células HB4a. Nas células C5.2 não houve alteração dos transcritos TPM1 após os tratamentos com EGF sugerindo que nestas células o aumento desse gene é decorrente de sinalização constitutiva do ERBB2.

O tratamento com HRG não modulou a expressão do gene TMP1 nas células HB4a, enquanto nas células SKBr3 foi observada uma redução após 2 horas de tratamento, indicando que a HRG regula a expressão do gene TPM1 via ERBB2.

\subsection{CENPH}

O gene CENPH codifica a proteína CENP-H que pertence a uma família de proteínas que se associam as centrômeros conhecidas como CENPs. CENP-H são proteínas essenciais localizadas nos centrômeros ativos, incluindo os neocentrômeros, fundamentais para a formação do cinetócoro (DAVID et al., 2004). O cinetocoro funciona como sítio de ligação para os fusos do microtúbulo, os quais são importantes para a segregação adequada dos cromossomos durante a mitose (FUKAGAWA et al., 2004).

Estudo utilizando nocaute de CENP-H em células DT40 mostrou que a proteína CENP-H é essencial para o crescimento celular e progressão da mitose (FUKAGAWA et al., 2001). Orthaus et al. (2006) mostraram que a diminuição da expressão de CENPH em células humanas HEp-2 resulta em alinhamento incorreto dos cromossomos na metáfase e fusos multipolar. A segregação incorreta dos cromossomos durante a mitose pode gerar células aneuplóides. Muitos tumores sólidos são aneuplóides e várias linhagens celulares de câncer possuem instabilidade cromossomal, significando que as células frequentemente perdem ou ganham cromossomos inteiros durante a divisão (KOPS et al., 2005).

Neste estudo observamos que os transcritos do CENPH estavam menos expressos nas células com expressão aumentada de ERBB2. Esses dados são diferentes dos resultados observados anteriormente por nosso grupo pela técnica de SAGE (DOS SANTOS et al., 2006). Observamos também, que a supressão do ERBB2 por siRNA leva ao aumento da expressão do CENPH, 
indicando que o aumento da expressão de ERBB2 influencia na expressão destes transcritos.

Nas três linhagens utilizadas o tratamento com EGF reduz a expressão dos transcritos $C E N P H$. Após o tratamento com HRG apenas as células que possuem altos níveis de ERBB2 apresentaram redução na expressão dos transcritos do $C E N P H$, o que indica que a alteração da expressão deste gene é via ERBB2.

\subsection{ATAD4}

O gene ATAD4 localizado no cromossomo 17q21.32 codifica para uma proteína pertencente a família de ATPase. Neste trabalho foi observado aumento da expressão dos transcritos do ATAD4 nas células C5.2 e SKBr3, confirmando estudo anterior do nosso grupo (DOS SANTOS et al., 2006).

A expressão dos transcritos do ATAD4 foi sensível a redução de soro nas células HB4a. Enquanto que nas células com expressão aumentada de ERBB2, C5.2 e SKBr3, a redução de soro não alterou a expressão deste gene.

Os tratamentos com EGF e HRG reduzem a expressão dos transcritos do ATAD4 nas células HB4a, C5.2 e SKBr3. Esses resultados indicam que a diminuição dos transcritos do ATAD4 podem ser devido à sinalização EGFR; primeiro porque as maiores reduções foram observadas nas células $\mathrm{HB} 4 \mathrm{a}$, que possuem maiores níveis de EGFR; e porque a HRG não fosforila os receptores ERBB2 nas células HB4a que possuem expressão normal destes receptores.

Após a transfecção das células $\mathrm{C} 5.2$ com siERBB2 houve uma redução significativa na expressão dos transcritos do $A T A D 4$, o que demonstra que a expressão aumentada observada nas células C5.2 é devido aos maiores níveis de ERBB2. A diminuição da expressão do ATAD4 nas células C5.2 ocorreu independente do ligante, indicando que a regulação desse gene dependente diretamente dos níveis de ERBB2 ou da sua ativação constitutiva. 
CONCLUSÃO 


\section{CONCLUSÃO}

* O EGF regula positivamente a expressão dos transcritos dos genes ACTN1 e TPM1 e reprimiu a expressão dos transcritos dos genes ADTAD4, NDRG1, CENPH e SPARC nas células HB4a.

* Após o tratamento com EGF houve aumentou a expressão dos transcritos dos genes NDRG1, MATR3, ACTN1 e CENPH e redução dos transcritos dos genes ADTAD4 e SPARC nas células C5.2

* A exposição ao EGF induziu a expressão dos transcritos dos genes MATR3 e ACTN1 e reprimiu a expressão dos transcritos do ADTAD4, NDRG1 e CENPH nas células SKBr3.

* O tratamento com HRG reduziu a expressão dos transcritos dos genes ATAD4 e NDRG1 nas células HB4a e SKBr3.

* O tratamento com HRG nas células SKBr3 aumentou a expressão dos transcritos dos genes ACTN1 e TPM1 e reduziu a expressão dos transcritos do CENPH.

* A expressão dos transcritos dos genes ATAD4, NDRG1, TPM1 e CENPH foi influenciada diretamente pela expressão aumentada de ERBB2 nas células C5.2. 


\section{REFERÊNCIAS BIBLIOGRÁFICAS}

ADAMO, V.; FRANCHINA, T.; ADAMO, B.; FERRARO, G.; ROSSELLO, R.; SACCÀ, M. M.; SCIBILIA, C.; VALERIO, M. R.; RUSSO, A. Safety and activity of trastuzumab-containing therapies for the treatment of metastic breast cancer: our long-term clinical experience (GOIM study). Ann. Oncol., v. 18, p. vi11vi15, 2007.

BADACHE, A.; GONÇALVES, A. The ErbB2 signaling network as a target for breast cancer therapy. J. Mammary Gland Biol. Neoplasia., v. 11, p. 13-25, 2006.

BALSEGA, J. Clinical trials of Herceptina (tratuzumab). Eur. J. Cancer, v. 37, p. S18-24, 2001.

BANDYOPADHYAY, S.; PAI, S. K.; HIROTA, S.; HOSOBE, S.; TAKANO, Y.; SAITO, K.; PIQUEMAL, D.; COMMES, T.; WATABE, M.; GROSS, S. C.; WANG, Y.; RAN, S.; WATABE, K. Role of the putative tumormetastasis supressos gene Drg-1 in breast cancer progression. Oncogene, v.23, p.5675$5681,2004$.

BARCUS, M. E.; GONZALEZ, A. F.; BULLER, A. M.; WILKINSON, D. S.; GARRETT, C. T. Genetic Changes in Solid Tumors. Semin. Surg. Oncol., v.18, p. 358-370, 2000.

BARTH, P. J.; MOLL, R.; RAMASWAMY, A. Stromal remodeling and SPARC (secreted protein acid rich in cysteine) expression in invasive ductal carcinomas of the breast. Virchows Arch., v. 446, p. 532-536, 2005.

BECKERS, J.; HERRMANN, F.; RIEGER, S.; DROBYSHEV, A. L.; HORSCH, M.; HRABE' DE ANGELIS, M.; SELIGER, B. Identification and validation of novel ERBB2 (HER2, NEU) targets including genes involved in angiogenesis. Int. J. Cancer, v. 114, p. 590-597, 2005.

BHARADWAJ, S.; THANAWALA, R.; BON, G.; FALCIONI, R.; PRASAD, G. L.. Resensitization of breast cancer cells to anoikis by Tropomyosin-1: role of Rho kinase-dependent cytoskeleton and adhesion. Oncogene, v. 24, p. 8291-8303, 2005.

BRIGGS, J.; CHAMBOREDON, S.; CASTELLAZZI, M.; KERRY, J. A.; BOS, T. J. Transcriptional upregulation of SPARC, in response to c-Jun overexpression, contributes to increased motility and invasion of MCF7 breast cancer cells. Oncogene, v. 21, p. 7077-7091, 2002.

CABELLO, N.; REMELLI, R.; CANELA, L.; SORIGUERA, A.; MALLOL, J.; CANELA, E. I.; ROBBINS, M.; LLUIS, C.; FRANCO, R.; MCLLHINNEY, R. A. J.; CIRUELA, F. Actin-binding protein a-Actinin - 1 interacts with the metabotropic glutamate receptor type $5 \mathrm{~b}$ and modulates the cell surface expression and function of the receptor. J. Biol. Chem., v. 282, p. 12143-12153, 2007. 
CANGUL, H.; SALNIKOV, K.; YEE, H.; ZAGZAG, D.; COMMES, T.; COSTA, M. Enhanced expression of a novel protein in human cancer cells: A potencial aid to cancer diagnosis. Cell Biol. Toxicol., v. 18, p. 87-96, 2002.

CASALINI, P.; IORIO, M. V.; GALMOZZI, E.; MENARD, S. Role of HER receptors family in development and differentiation. J. Cell Physiol. v. 200, n.3, p.343-50, 2004.

CHEN, J. S.; LAN, K.; HUNG, M. C. Strategies to target HER2/neu overexpression for cancer therapy. Drug Resist. Updat., v. 6, p.129-36, 2003.

CHLENSKI, A.; LIU, S.; GUERRERO, L. J.; YANG, Q.; TIAN, Y.; SALWEN, H. R.; ZAGE, P.; COHN, S. L. SPARC expression is associated with impaired tumor growth, inhibited angiogenesis and changes in the extracellular matrix. Int. J. Cancer, v. 118, p. 310-316, 2006.

CHO, H. S.; MASON, K.; RAMYAR, K. X.; STANLEY, A. M.; GABELLI, S. B.; DENNY, D. W.; LEAHY, D. J. Struture of the extracellular region of HER2 alone and in complex with the Herceptin Fab. Nature, v.421, p. 756-760, 2003.

CHOMCZYNSKI, P.; SACCHI, N. Single-Step Method of RNA Isolation by Acid Guanidinium Thiocyanate-Phenol-Chloroform Extraction. Annal. Biochem., v. 162, p. 156-159, 1987.

CHRISTERSON, L. B.; VANDERBILT, C. A.; COBB, M.H. MEKK1 interacts with a-Actinin and localizes to stress fibers and focal adhesions. Cell Motil. Cytoskeleton, v. 43, p. 186-198, 1999.

CITRI, A.; YARDEN, Y. EGF-ERBB signalling: towards the systems level. Mol. Cell Biol., v. 7, p. 505-516, 2006.

CLAMP, A.; DANSON, S.; CLEMONS M. Hormonal risk factors for breast cancer: identification, chemoprevention, and other intervention strategies. Lancet, v. 3, p.611-619, 2002.

COBLEIGH, M. A.; VOGEL, C. L.; TRIPATHY, D.; ROBERT, N. J.; SCHOLL, S.; FEHRENBACHER, L.; WOLTER, J. M.; PATON, V.; SHAK, S.; LIEBERMAN, G.; SLAMON, D. J. Multinational Study of the Efficacy and Safety of Humanized Anti-HER2 Monoclonal Antibody in Women Who Have HER2Overexpressing Metastatic Breast Cancer That Has Progressed After Chemotherapy for Metastatic Disease. J. Clin. Oncol., v. 17, p. 2639-2648, 1999.

DE JONG, M. M.; NOTLE, I. M.; TE MEERMAN, G. J.; VAN DER GRAAF, W. T.; OOSTERWIJK, J. C.; KLEIBEUKER, J. H.; SCHAAPVELD, M.; DE VRIES, E. G. Genes other than BRCA1 and BRCA2 involved in breast cancer susceptibility. J. Med. Genet., v. 39, p. 225-242, 2002.

DIERMEIER, S.; HORVÁTH, G.; KNUECHEL-CLARKE, R.; HOFSTAEDTER, F.; SZOLLOSI, J.; BROCKHOFF, G. Epidermal growth factor receptor 
coexpression modulates susceptibility to Herceptin in HER2/neu overexpressing breast cancer cells via specific erbB-receptor interation and activation. Exp. Cell Res., v. 304, p. 604-619, 2005.

DHANESUAN, N.; SHARP, J. A.; BLICK, T.; PRICE, J. T.; THOMPSON, E. W. Doxycycline-inducible expression of SPARC/Osteonectin/B $<40$ in MDA-MB-231 human breast cancer cells results in growth inhibition. Breast Cancer Res. Treat., v. 75, p.73-85, 2002.

DOS SANTOS, M. L.; PALANCH, C. G.; SALAORNI, S.; SILVA JR, W. A.; NAGAI, M. A. Transcriptome characterization of human mammary cell lines expressing different levels of ERBB2 by serial analysis of gene expression. Int. J. Oncol, v. 28, n. 6, p.1441-61, 2006.

DOWSETT, M.; HARPER-WYNNE, C.; BOEDDINGHAUS, I.; SALTER, J.; HILLS, M.; DIXON, M.; EBBS, S.; GUI, G.; SACKS, N.; SMITH, I. HER-2 Amplification Impedes the Antiproliferative Effects of Hormone Therapy in Estrogen Receptor-positive Primary Breast Cancer. Cancer Res., v. 61, p. 8452-8458, 2001.

FRALEY, T. S.; PEREIRA C. B.; TRAN, T. C.; SINGLETON, C.; GREENWOOD, G. F. Phosphoinositide binding regulates a-Actinin dynamics. J. Biol. Chem., v. 280, p. 15479-15482, 2005.

FRAMSON, P. E.; SAGE, H. SPARC and tumor growth: where the seed meets the soil? J. Cell. Biochem., v. 92, p. 679-690, 2004.

FOTOVATI, A.; FUJII, T.; YAMAGUCHI, M.; KAGE, M.; SHIROUZU, K.; OIE, S.; BASAKI, Y.; ONO, M.; YAMANA, H.; KUWANO, M. 17ß-estradiol induces down-regulation of Cap43/NDRG1/Drg-1, a putative ifferentiation-related and metastasis suppressor gene, in human breast cancer cells. Clin. Cancer Res., v. 12, p.30103018, 2006.

FUKAGAWA, T.; MIKAMI, Y.; NISHIHASHI, A.; REGNIER, V.; HARAGUCHI, T.; HIRAOKA, Y.; SUGATA, N.; TODOKORO, K.; BROWN, W.; IKEMURA, T. $\mathrm{CENP}-\mathrm{H}$, a constitutive centromere component, is required for centromere targeting of CENP-C in vertebrate cells. EMBO J. v. 20, n. 16, p.4603-17, 2001.

GARRETT, T. P. J.; MCKERN, N. M.; LOU, M.; ELLEMAN, T. C.; ADAMS T. E.; LOVRECZ, G. O.; KOFLER, M.; JORISSEN, R. N.; NICE, E. C.; BURGESS, A. W.; WRAD, C. W. The crystal structure of a truncated ErbBe ectodomain reveals an active conformation, poised to interact with other ErbB receptors. Mol. Cell, v.11, p. 495-505, 2003.

GRAUS-PORTA, D.; BEERLI, R. R.; DALY, J. M.; HYNES, N. E. ErbB-2, the preferred heterodimerization partner of all ErbB receptors, is a mediator of lateral signaling. EMBO J., v. 16, p. 1647-1655, 1997.

GREENFIELD, C.; HILES, I.; WATERFIELD, M. D.; FEDERWISCH, M.; WOLLMER, A.; BLUNDELL, T. L.; MCDONALD, N. Epidermal growth factor 
binding induces a conformational changes in the external domain of its receptor. EMBO J., v. 8, p. 4115-4123, 1989.

HANAHAN, D.; WEINBERG, R. A. The hallmarks of cancer. Cell, v. 7;100, n.1, p. $57-70,2000$.

HANNON, G. J. RNA interference. Nature, v. 418, p. 244-251, 2002.

HARRIS, R. A.; EICHHOLTZ, T.;HILES, I. D.; PAGE, M. J.; O'HARE, M. J. New model of ErbB-2 over-expression in human mammary luminal epithelial cells. Int. J. Cancer, v. 80, p. 477-484, 1999.

HAZAN, R. B.; NORTON, L. The Epidermal Growth Factor Receptor Modulates the Interaction of E-cadherin with the Actin Cytoskeleton. J. Biol. Chem., v. 273, p. 9078-9084, 1998.

HUNG, M. C.; LAU, Y. K. Basic Science of Her-2/neu: A review. Semin. Oncol., v. 26, p. $51-59,1999$.

HUSSEIN, M. R.; ABD-ELWAHED, S. R. A. H.; ABDULWAHED, A.R. Alterations of estrogen receptors, progesterone receptors and C-erbB2 oncogene protein expression in ductal carcinomas of the breast. Cell Biol. Int.,, v. XX, p. 1-10, 2008.

HYNES, N. E.; LANE, H.A. ERBB receptors and cancer: the complexity of targeted inhbitors. Nature, v. 5, p. 341-354, 2005.

KOBLINSKI, J. E.; KAPLAN-SINGER, B. R.; VANOSDOL, S. J.; WU, M.; ENGBRING, J. A.; WANG, S.; GOLDSMITH, C. M.; PIPER, J. T.; VOSTAL, J. G.; HARMS, J. F.; WELCH, D. R.; KLEINMAN, H. K. Endogenous Osteonectin/SPARC/BM-40 expression inhibits MDA-MB-231 breastcancer cell metastasis. Cancer Res., v. 65, n. 16, p. 7370-7377, 2005.

KOPS, G. J.; WEAVER, B. A.; CLEVELAND, D. W. On the road to cancer: aneuploidy and the mitotic checkpoint. Nat. Rev. Cancer., v. 5, n.10, p.773-85, 2005.

KURDISTANI, S. K.; ARIZTI, P.; REIMER, C. L.; SUGRUE, M. M.; AARONSON, S. A.; LEE, S. W. Inhibition of tumor cell growth by RTP/rit42 and its responsiveness to p53 and DNA damage. Cancer Res., v. 58, p. 4439-4444, 1998.

LACHAT, P.; SHAE, P.; GEBHARD, S.; BELZEN, N. V.; CHAUBERT, P.; BOSMAN, F. T. Expression os NDRG1, a differentiation-related gene, in human tisuues. Histochem. Cell. Biol., v. 118, p. 399-408, 2002.

LEE, A.; PARK, W. C.; YIM, H. W.; LEE, M. A.; PARK, G.; LEE, K. Y. Expression of c-erbB2, cyclin D1 and estrogen receptor and their clinical implications in the invasive ductal carcinoma of the breast. Jpn. J. Clin. Oncol., v. 37, n. 9, p. 708-714, 2007. 
LIU, W.; LI, J.; ROTH, R. A. Heregulin regulation of AKT/protein kinase B in breast câncer cells. Biochem. Biophys Res. Commun., v. 261, p. 897-903, 1999.

MACKAY, A.; JONES, C.; DEXTER, T.; SILVA, R. L. A.; BULMER, K.; JONES, A.; SIMPSON, P.; HARRIS, R. A.; JAT, P. S.; NEVILLE, A. M.; REIS, L. F. L.; LAKHAMI, S. R.; O'HARE, M. J. cDNA microarray analysis of genes associated with ERBB2 (HER2/neu) overexpression in human mammary luminal epithelial cells. Oncogene, v.22. p. 2680-2688, 2003.

MAHADEV, K.; RAVAL, G.; BHARADWAJ, S.; WILLINGHAM, M. C.; LANGE, E. M.; VONDERHAAR,B.; SALOMON, D.; PRASAD, G. L. Suppression of the Transformed Phenotype of Breast Cancer by Tropomyosin-1. Exp. Cell Res., v. 279, p. 40-51, 2002.

MAKRIS, A.; POWLES, T.J.; DOWSETT, M.; OSBORNE, C.K.; TROTT, P.A.; FERNANDO, I.N.; ASHLEY, S.E.; ORMEROD, M.G.; TITLEY, J.C.; GREGORY, R.K.; ALLRED, D.C. Prediction of response to neoadjuvant chemoendocrine therapy in primary breast carcinomas. Clin. Cancer Res., v. 3, p. 593-600, 1997.

MCPHERSON, K.; STEEL, C. M.; DIXON, J. M. Breast Cancer - Epidemiology, Risk Factors and Genetics. BMJ, v. 321, p. 624-628, 2000.

MCCUBREY, J.A.; STEELMAN, L.S.; CHAPPELL, W. H.; ABRAMS, S. L.; WONG, E. W. T.; CHANG, F.; LEHMANN, B.; TERRIAN D. M.; MILELLA, M.; TAFURI, A.; STIVALA, F.; LIBRA, M.; BASECKE, J.; EVANGELISTI, C.; MARTELLI, A. M.; FRANKLIN, R. A. Roles of the Raf/MEK/ERK pathaway in cell growth, malignant transformation and drug resistence. Biochim. Biophys. Acta, v.1773, p. 1263-1284, 2007.

MELLONE, B.; ERHARDT, S.; KARPEN, G. H. The ABCs of centromeres. Nat. Cell Biol., v. 8, n.5, p.427-9, 2006.

MOSESSON, Y.; YARDEN, Y. Oncogenic growth factor receptors: implications for signal transduction therapy. Semin. Cancer Biol., v. 14, p. 262-270, 2004.

MUTHUSWAMY, S. K.; GILMAN, M.; BRUGGE, J. S. Controlled dimerization of ErbB receptors provides evidence for differential signaling by homo- and heteradimers. Mol. Cell. Biol., v. 19, p. 6845-6857, 1999.

NAGAI, M. A.; MARQUES, L. A.; TORLONI, H.; BRENTANI, M. M. Genetic alterations in c-erbB-2 protooncogene as prognostic markers in human primary breast tumors. Oncology, v. 50, p. 412-7, 1993.

NICHOLSON, K. M.; ANDERSON N. G. The protein kinase B/Akt signalling pathaway in human malignancy. Cell. Signal., v.14, p.381-395, 2002. 
NISHIO, S.; USHIJIMA, K.; TSUDA, N.; TAKEMOTO, S.; KAWANO, K.; YAMAGUCHI, T.; NISHIDA, N.; KAKUMA, T.; TSUDA, H.; KASAMATSU, T.; SASAJIMA, Y.; KAGE, M.; KUWANO, M.; KAMURA, T. Cap 43/NDRG1/Drg-1 is a molecular target for angiogenesis and a prognostic indicator in cervical adenocarcinoma. Cancer Lett., v. 264, p. 36-43, 2008.

NIU, G.; CARTER, W. B. Human epidermal growth factor receptor 2 regulates angiopoietin-2 expression in breast cancer via AKT and mitogen-activated protein kinase pathways. Cancer Res., v.67, p. 1487-93, 2007.

O’NEILL, G. M.; STEHN, J.; GUNNING, P. W. Tropomyosins as interpreters of the signalling environment to regulate the local cytoskeleton. Semin. Cancer Biol., v. 18, p. 35-44, 2008.

OLDENBURG, R.A.; MEIJERS-HEIJBOER, H.; CORNELISSE, C.J.; DEVILEE, P. Genetic susceptibility for breast cancer: How many more genes to be found? Crit. Rev. Oncol. Hematol., 2007.

ORTHAUS, S.; OHNDORF, S.; DIEKMANN, S. RNAi knockdown of human kinetochore protein CENP-H. Biochem. Biophys. Res. Commun, v. 348, n. 1, p.36-46, 2006.

OTEY, C. A.; CARPEN, O. a-Actinin Revisited: a fresh look at an old player. Cell Motil. Cytoskeleton, v. 58, p. 104-111, 2004.

PAL, S. K.; PEGRAM, M. HER2 targeted therapy in breast cancer...beyond Herceptin. Rev. Endocr. Metab. Disord., v. 8, p. 269-277, 2007.

PAWLAK , G.; HELFMAN, D. M. Cytoskeletal changes in cell transformation and tumorigenesis. Curr. Opin. Genet. Dev., v. 1, p.41-7, 2001.

PEGRAN, M. D.; FINN, R. S.; ARZOO, K.; BERYT, M.; PIETRAS, R. J.; SLAMON, D. J. The effect of Her-2/neu overexpression on chemotherapeutic drug sensitivity in human breast and ovarian cancer cells. Oncogene, v. 15, p. $537-47,1997$.

PICCART-GEBHART, M. J.; PROCTER, M.; LEYLAND-JONES, B.; GOLGHIRSCH, A.; UNTCH, M.; SMITH, I.; GIANNI, L.; BASELGA, J.; BELL, R.; JACKISCH, C.; CAMERON, D.; DOWSETT, M.; BARRIOS, C. H.; STEFER, G.; HUANG, C.; ABDERSSON, M.; INBAR, M.; LICHINITSER, M.; LÁNG, I.; NITZ, U.; IWATA, H.; THOMSSEN, C.; LOHRISCH, C.; SUTER, T. M.; RUSCHOFF, J.; SUTO, T.; GREATORES, V.; WARD, C.; STRAEHLE, C.; MCFADDEN, E.; DOLCI, S.; GELBER, R.D. Trastuzumab after Adjuvant Chemotherapy in HER2- positive breast cancer. N. Engl. J. Med., v. 353, p.1659-1672, 2005.

PONDER, B.A.J. Cancer genetics. Nature, v. 411, p.336-341, 2001.

QU, X.; ZHAI, Y.; WEI, H.; ZHANG, C.; XING, G.; YU, Y.; HE, F. Characterization and expression of three novel differentiation-related genes 
belong to the human NDRG1 gene family. Mol. Cell. Biochem., v. 229, p. 3544, 2002.

RABINDRAN, S. K. Antitumor activity of HER-2 inhibitors. Cancer Lett., v. 227, p. 9-23, 2005.

RAVAL, G. N.; BHARADWAJ, S.; LEVINE, E. A.; WILLINGHAM, M. C.; GEARY, R. L.; KUTE, T.; PRASAD, G. L. Loss of expression of tropomyosin-1, a novel class II tumor supressos that induces anoikis, in primary breast cancer. Oncogene, v.22, p. 6194-6203, 2003.

ROSKOSKI, R J. The ErbB/HER receptor protein-tyrosine kinases and cancer. Biochem. Biophys. Res. Commun., v. 319, p. 1-11, 2004.

SAGE, E. H.; REED, M.; FUNK, S. E.; TRUONG, T.; STEADELE, M.; PUOLAKKAINEN, P.; MAURICE, D. H.; BASSUK, J. A. Cleavage of the Matricellular Protein SPARC by Matrix Metalloproteinase 3 Produces Polypeptides That Influence Angiogenesis. J. Biol. Chem., v. 278, n. 39, p. 37849-37857, 2003.

SALNIKOW, K.; BLAGOSKLONNY, M. V.; RYAN, H.; JOHNSON, R.; COSTA, $M$. Carcinogenic Nickel induces genes involved with hypoxic stress. Cancer Res., v. 30, p. 38-41, 2000.

SALNIKOW, K.; KLUZ, T.; COSTA, M.; PIQUEMAL, D.; DEMIDENKO, Z. N.; $\mathrm{XIE}, \mathrm{K}$.; BLAGOSKLONNY, M. V. The regulation of hipoxic genes by calcium involves C-Jun/AP-1, which cooperates with hypoxia inducible factor 1 in response to hipoxia. Mol. Cell. Biol., p. 1734-1741, 2002.

SCHIFF, R.; MASSARWEH, S. A.; SHOU, J.; BHARWANI, L.; ARPINO, G.; RIWAWI, M.; OSBORNE, C. K. Advanced concepts in estrogen receptor biology and breast cancer endocrine resistance: implicated role of growth factor signaling and estrogen receptor coregulators. Cancer Chemother. Pharmacol., 2005.

SIBOLD, S.; ROH, V.; KEOGH, A.; STUDER, P.; TIFFON, C.; ANGST, E.; VORBURGER, S. A.; WEIMANN, R.; CANDINAS, D.; STROKA, D. Hypoxia increases cytoplamic expression of NDRG1, but is insufficient for its membrane localization in human hepatocellular carcinoma. FEBS Lett., v. 581, p.989-994, 2007.

SLAMON, D.J.; CLARK, G.M.; WONG, S.G. Human breast cancer: correlation of relapse and survival with amplification of the HER-2/neu oncogene. Science, v. 235 , p. $177-82,1987$.

SONG G.; OUYANG, G.; BAO, S. The activation of AKT/PKB signalin pathaway and cell survival. J. Cell. Mol. Med., v. 9, p.59-71, 2005. 
STEIN, S.; THOMAS, E. K.; HERZOG, B.; WESTFALL, M. D.; ROCHELEAU, J. V.; JACKSON, R. S.; WANG, M.; LIANG, P. NDRG1 is necessary for p53dependent apoptosis. J. Biol. Chem., v. 279, p.48930-48940, 2004.

SUGATA, N.; LI, S.; EARNSHAW, W. C. Human CENP-H multimers colocalize with CENP-A and CENP-C at active centromere--kinetochore complexes. Hum. Mol. Genet., v. 9, p. 2919-26, 2000.

TAI, I. T.; DAI, M.; OWEN, D. A..; CHEN, L. B. Genome-wide expression analysis of therapy-resistant tumors reveals SPARC as a novel target for cancer therapy. J. Clin. Invest., v. 115, p. 1492-502, 2005.

TIMMS, J. F.; WHITE, S. L.; O HARE, M. J.; WATERFIEL, M. D. Effects of ErbB-2 overexpression on mitogenic signaling and cell cycle progression in human breast luminal epithelial cells. Oncogene, v. 21, p. 6573-6586, 2002.

TOKUNAGA, E.; KIMURA, Y.; UEDA, E. O. N.; FUTATSUGI, M.; MASHINO, K.; YAMAMOTO, M.; IKEBE, M.; KAKEJI, Y.; BABA, H.; MAEHARA, Y. Akt is frequently activated in HER2/neu-positive breast cancers and associated with poor prognosis among hormone-treated patients. Int. J. Cancer, v. 118, p. 284289, 2006.

TRICHOPOULOS, D.; ADAMI, H. O.; EKBOM, A.; HSIEH C. C.; LAGIOU, P. Early life events and conditions and breast cancer risk: From epidemiology to etiology. Int. J. Cancer, v.122, p.481-485, 2008.

TOMONAGA, T.; MATSUSHITA, K.; ISHIBASHI, M. Centromere protein $\mathrm{H}$ is up-regulated in primary human colorectal cancer and its overexpression induces aneuploidy. Cancer Res.; v. 65, p. 4683-9, 2005.

UENO, N. T.; YU, D.; HUNG, M. C. Chemosensitization of HER/neuoverexpressing human breast cancer cells to paclitaxel (Taxol) by adenovirus type 5 E1A. Oncogene, v. 15, p. 953-60,1997.

ULLRICH, A.; SCHLESSINGER, J. Signal transduction by receptors with tyrosine kinase activity. Cell, v. 61, p. 203-212, 1990.

VALENCIA, C. A.; JU, W.; LIU, R. Matrin 3 is a Ca2+/calmodulin-binding protein cleaved by caspases. Biochem. Biophys. Res. Commun., v.361, p. 281-6, 2007.

VOGEL, C. L.; COBLEIGH, M. A.; TRIPATHY, D.; GUTHEIL, J. C.; HARRIS, L. N.; FEHRENBACHER, L.; SLAMON, D. J.; MURPHY, M.; NOVOTNY, W. F.; BURCHMORE, M.; SHAK, S.; STEWART, S. J.; PRESS, M. Efficacy and safety of trastuzumab as a single agent in first-line treatment of HER2-overexpressing metastatic breast cancer. J. Clin. Oncol., v.20, p. 719-26, 2002.

WATKINS, G.; DOUGLAS-JONES, A.; BRYCE, R.; MANSEL, R.E. JIANG, W. G. Increased levels of SPARC (osteonectin) in human breast cancer tissues 
and its association with clinical outcomes. Prostaglandins Leukot. Essent. Fatty Acids, v. 72, p. 267-272, 2005.

WARREN, C.M.; LANDGRAF, R. Signaling through ERBB receptors: Multiple layers of diversity and control. Cell. Signal., v.18, p.923-933, 2006.

WHITE, S. L.; GHARBI, S.; BERTANI, M. F.; CHAN, H. L.; WATERFIELD, M. D.; TIMMS, J. F. Cellular responses to ErbB-2 overexpression in human mammary liminal epithelial cells: comparison os mRNA and protein expression. Br. J. Cancer, v.90, p. 173-181, 2004.

WONG, S. Y.; CROWLEY, D.; BRONSON, R. T.; HYNES, R. O. Analyses of the role of endogenous SPARC in mouse models of prostate and breast cancer. Clin. Exp. Metastasis, v. 25, p. 109-118, 2008.

WONG, M. L.; MEDRANO, J .F. Real-time PCR for mRNA quantitation. BioTechniques, v. 39, 2005.

YARDEN, Y. The EGFR family and its ligands in human cancer. Signalling mechanisms and therapeutic opportunities. Eur. J. Cancer, v. 37, p. S3-S8, 2001.

YARDEN, Y.; SLIWKOWSKI, M. X. Untangling the erbB signaling network. Nat. Rev. Mol. Cell. Biol., v 2, p. 127-137, 2001

YEON, C. H.; PEGRAM, M. D. Anti-erbB-2 antibody trastuzumab in the treatment of HER2-amplified breast cancer. Invest. New Drugs, v.23, p.391409, 2005.

ZACZEK, A.; WELNICKA-JASKIEWIEZ, M.; BIELAWSKI, K. P.; JASKIEWICZ, J.; BADZIO, A.; OLSZEWSKI, W.; RHONE, P.; JASSEM, J. Gene copy numbers of HER family in breast cancer. J. Cancer Res. Clin. Oncol., 2007. 